Portland State University

PDXScholar

1990

\title{
The German exile journal Das Wort and the Soviet Union
}

James W. Seward

Portland State University

Follow this and additional works at: https://pdxscholar.library.pdx.edu/open_access_etds

Part of the German Literature Commons, and the History Commons Let us know how access to this document benefits you.

\section{Recommended Citation}

Seward, James W., "The German exile journal Das Wort and the Soviet Union" (1990). Dissertations and Theses. Paper 4104.

https://doi.org/10.15760/etd.5988

This Thesis is brought to you for free and open access. It has been accepted for inclusion in Dissertations and Theses by an authorized administrator of PDXScholar. Please contact us if we can make this document more accessible: pdxscholar@pdx.edu. 
AN ABSTRACT OF THE THESIS OF James $W$. Seward for the Master of Arts in German presented April 24, 1990.

Title: The German Exile Journal Das Wort and the Soviet Union

APPROUED BY THE MEMBERS OF THE THESIS COMMITTEE:

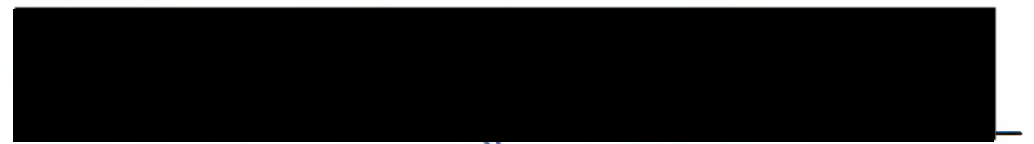

Franz Langhammer, Chair

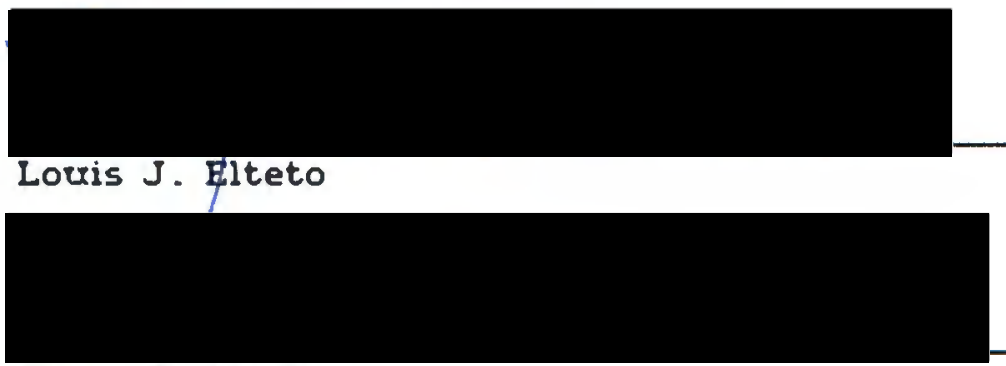

Timm R. Menke

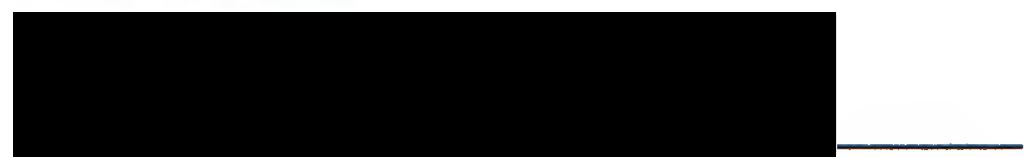

Franklin C. West

Das Wort was a literary journal published by German Communist writers and fellow-travelers exiled in Moscow from 1936 to 1939. It was to be mouthpiece for German literature in exile and to promote the Popular Front policy, which sought to unite disparate elements in non-Faschist Europe in opposition to the Maz1s. Das Wort, under the editorship of German Communist writers whose close association with 
the Soviet Union had been well established in the previous decade, tried to provide a forum for exiled writers of various political persuasions, but was unwavering in its positive portrayal of Stalin's Soviet Union and the policies of that country. As the level of hysteria grew with the successive purges and public show trials in the Soviet Union, the journal adopted an even more eulogistic and militant attitude: $2 n y$ criticism or expression of doubt about Soviet policy was equated with support for Faschism. Thus the ability of the journal to contribute to the formation of a true common front in Europe to oppose Faschism was compromised from the outset by its total support for the Soviet Union. The Popular Front policy foundered on this issue, and that portion of German literature in exile which was to form the first generation of East German literature was inextricably bound to the Soviet Union well before the German Democratic Republic came into existence.

Using a complete facsimile edition of Das Wort available in the Portland State University library, and scholarly materials covering both the political and literary history of the German Left in the 1920 's and 1930's, my thesis examines the process by which German Communism became subservient to Soviet direction, and the image of the Soviet Union which was presented in Das Wort. Chapter I is a short introduction which presents the general situation and raises the topic of politics and literature, which underlies everything which Das Wort represented and attempted to accomplish. Chapter II presents the political background to the situation of the German Communists in exile, and the origins of the Popular Front policy. 
Chapter III examines the reasons which motivated the leading Communist writers to publish Das Wort, as well as presenting in some detail the failed attempts by other journals published in Europe to provide a specifically literary journal to promote the Popular Front. Chapter IV concentrates on Das Wort's depiction of the Soviet Union as a new society in which the people have been transformed and the problem of nationalism has been resolved. Chapter $V$ examines the critical role the best elements of the old culture played in the development of a new culture. Soviet culture and literature are also discussed, and some aspects of German culture in its confrontation with both the old and new Russia. In Chapter VI, the Conclusion, I summarize the paradoxical situation in which the German Communist writers found themselves by trying to serve both Germany and the Soviet Union. I conclude by returning to the general topic of politics and literature, which is examined in the light of an essay by Hans Magnus Enzensberger.

The image of the Soviet Union presented in Das Wort was more than the depiction of a society whose humanistic and humane values stood in stark contrast to those of Nazi Germany; for the German Communist writers and political functionaries, this image was a model for the Germany which was to come into being following the inevitable collapse of Hitler's regime. A Soviet Germany, which was their goal, can be seen in the image of the Soviet Union which was presented in the pages of the German exile journal Das Wort. 
THE GERMAN EXILE JOURMAL DAS WORT AND THE SOUIET UNION

by

JAMES WESLEY SEWARD

A thesis submitted in partial fulfillment of the requirements for the degree of

MASTER OF ARTS

in

GERMAN

Portland State University

1990 
TO THE OFFICE OF GRADUATE STUDIES:

The members of the Committee approve the thesis of $\mathrm{J}$ ames $\mathrm{W}$. Seward presented April 24, 1990.

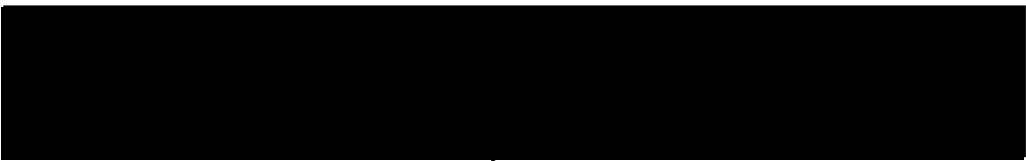

Franz Langhammer, Chair

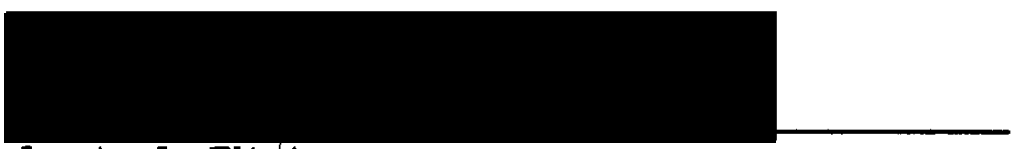

Louis J. Elteto

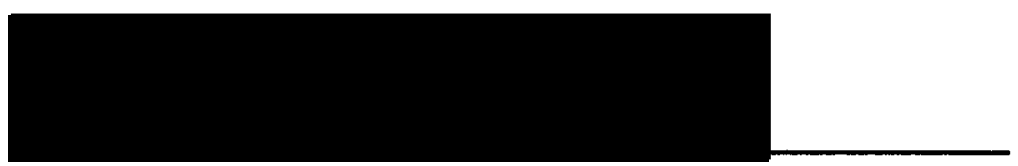

Timm R. Menke

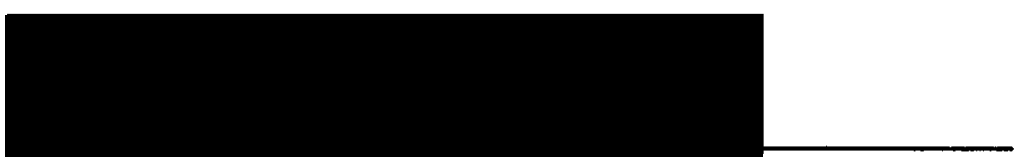

Franklin C. West

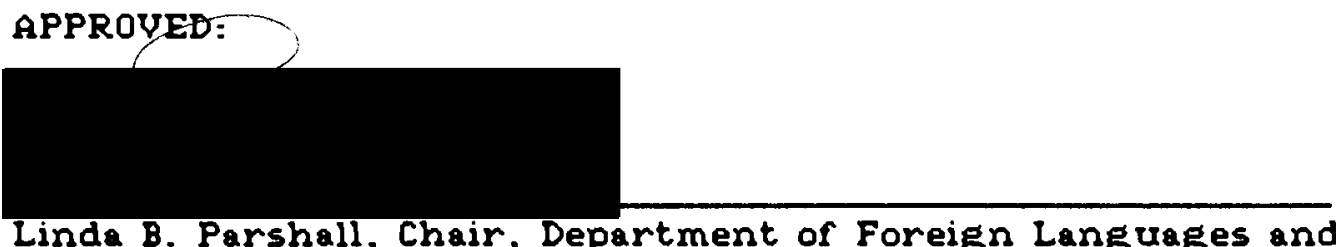

Literature

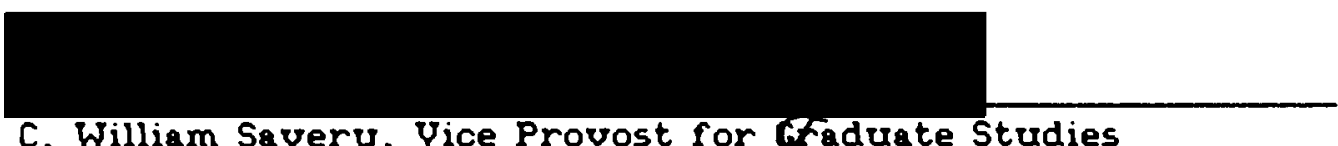

C. William Savery, Vice Provost for Gaduate Studies and Research 


\section{ACKNOWLEDGEMENTS}

I wish to extend very special thanks to my Magistervater, Dr. Franz Langhammer, Professor Emeritus at Portland State University, who suggested my topic long ago, and whose patience, knowledge, and understanding made possible completion of $\mathrm{my}$ thesis. I would also like to acknowledge the critical contribution to my efforts made by the starf and students of the Deutsche Sommerschule am Pazifik, the model institution of its kind, where my interest in German Studies and love of the language was rekindled. No words can properly express the gratitude due to all the members of my family who have for so long a time tolerated my erratic behavior as work on the thesis advanced or lagged. My mother in particular has had a difficult burden to bear, and has done so with love and consideration. My sister Kathleen Stokes and her employers, the Law Orfices of James Cox and Lawrence Peterson, deserve here special word of gratitude for providing critical support in all those onerous but necessary printing and copying tasks associated with producing my thesis. Finally, I would like to sincerely thank my very special friend Rose Plachta, whose firm words of encouragement, administered with genuine concern and love, kept me going when I was flagging. 
TABLE OF CONTENTS

PAGE

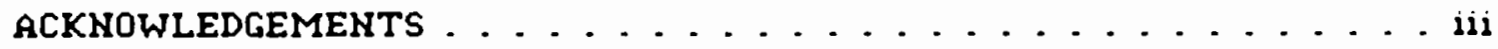

\section{CHAPTER}

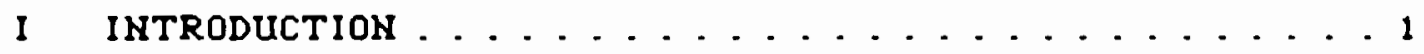

Notes to Chapter $1 \ldots \ldots . . \ldots 6$

II THE POLITICAL BACKGROUND ................ . . .

The Comintern and the German Communists ...... .

German Literature and the Russian Revolution . . . 17

The Popular Front and German Soviet Exile . . . . 25

Notes to Chapter II ................ 36

II DAS WORT: CHILD OF THE POPULAR FRONT ........ . 39

The Struggle against Fascism . . . . . . . . . 39

Personalities and Themes ............ 51

Notes to Chapter III ..............65

IV THE NEW MAN IN THE NEW STATE ........... 66

A Nation of Nations ................. 72

The People Great and Small ............ 82

Notes to Chapter IV .............. 94 
Y CULTURE IN THE NEW SOCIETY . . . . . . . . . . . . 95

The Russian Cultural Heritage . . . . . . . . . . 96 Soviet Culture ................... 104

Cerman Culture and the New Society . . . . . . . 11 ?

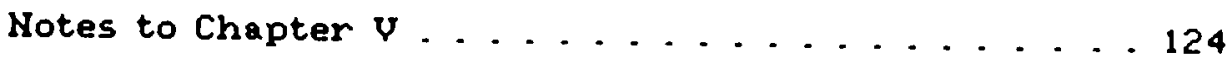

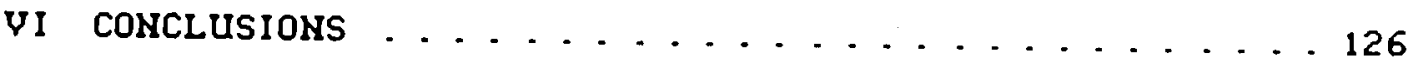

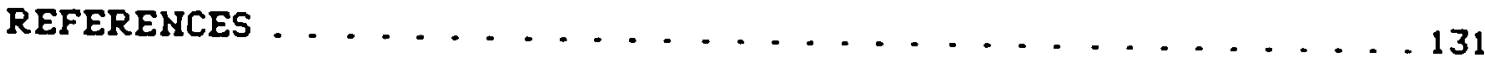




\section{CHAPTER I}

\section{INTRODUCTIOH}

Das Wort is a Cerman-language literary journal which appeared in the soviet Union from July 1936 until March 1939.1 It was promoted and funded by the Communist International. It was intended to contribute to the the policy known as the Popular Front, which sought to mobilize opposition to Fascism and the Mazis.

Das Wort was to provide a forum for German writers of all political persuasions united by a common desire to see Mazism destroyed. It would provide exiled writers the opportunity to publish, and would keep them informed of happenings pertinent to the anti-Fascist campaign in the arts and literature.

Despite some early successes, the Popular Front campaign was a railure. 3 The intellectuals and cultural prominenti who were the primary target of the activities of the Popular Front failed to persuade their governments to adopt the aggressive policies which would have been necessary to deter without war Hitler's drive to European hegemony. The rate of das wort is symptomatic of the primary reason for that failure: the Popular Front became a creature of the foreign policy of the Soviet union. Funded by the Comintern and directed by reliable literary runctionaries, Das Wort did not achreve balance or objectivity in its coverage of the Sovret union and its domestic and foreign policies. In this regard, Das Wort was 
essentially a Soviet journal in German guise. Das Wort presents the of ficial Soviet "party line" in cultural affairs. The image was meant to be a stark contrast to the policies pursued by the Mazis.

The stories, poems and articles about life in the Soviet union depicted a country whose wise leadership was developing the model of society which the rest of the world would one day emulate, once Fascism had been dereated. To the detriment of the Popular Front campaign, this portrayal lert little room for objectivity, let alone outright criticism. Thus writers and intellectuals driven into exile by the Hazis found themselves "out in the cold" if they did not soon express whole-hearted support of the Soviet Union. That country's international underground cultural and political apparat, the Comintern, helped those who supported them and tried to silence those who expressed criticism of Soviet activities. Infortunately ror the Communist writers, an important segment of German culture in exile, virtually all independence in artistic matters was lost to them.

The appearance of Das Wort colncided with the first "show trials" in Moscow. Joseph Stalin had set out to eliminate any possible rivals to his untrammeled control of the Communist Party and the country. The "Old Bolsheviks" were the initial victims of Stalin's terror. These venerable revolutionaries had been with the movement for decades and had made the revolution in 1917 with Vladimir Lenin. Such kudos were no protection for them against Stalin's secret police. By the end of the decade most of the original Bolshevik leaders had been wiped out.

An atmosphere of paranoia and the witch-hunt now pervaded 
Soviet society. "If you're not with us, you're against us," was the attitude adopted by Stalin and the surviving policy-makers. The German Communists in exile and Das Wort were not insulated from these events. They had to be even more orthodox and enthusiastic for prevaling policy than Soviet citizens themselves, since they were naturally the subject of hightened suspicion as aliens and citizens or a hostile roreign power. In such an atmosphere, there was little latitude for nuance when it came to writing about the Soviet Union. The Popular Front policy was transformed from opposition to Fascism into blatent support of all Soviet policy. The efficacy of that policy and the good it might have done in helping to thwart the plans or Adolf Hitler and perhaps prevent or limit the holocaust of World War II was thus doomed to failure from the outset.

The relationship between culture and politics, and literature and politics, is the crux of the issue exemplified by the Popular Front policy and its German literary magazine, Das Wort. Writers in every generation must of course deal with this problem. Party affiliation, engagement, commitment or autonomy, freedom of artistic expression, whatever it is called, it is an unavoidable aspect of a writer's work. A West German writer's approach to this problem can be seen in an essay by Hans Magnus Enzensberger. 3 His point is that "eulogy or the ruler and poetry are incompatible" ( 25 ). Yet poetry is political nevertheless. The apparent paradox hinges on your definition of political.

Enzensberger considers all excessively political poetry to be, in one fuise or another, simply eulogy of the ruler, an ancient genre 
which lost any validity as art with the enlightenment. Walter von der Yogelweide, Kleist and Goethe could produce work in this genre of some legitimacy, but by the time Theodore Fontane attempted to do so, the unintentionally humorous result was "proof of the disastrous impossibility of the task that Fontane, in all good faith, set himself" (Enzensberger 22).

Enzensberger presents a eulogistic poem to Stalin as a modern example of the genre ( 23 ). He admits that the reason why such "poems" rail and do not even deserve to be called poetry is not easily derined:

This scandal has nothing to do with craftsmanship; the text cannot be saved by any trick or artifice, or by eliminating the stupid comparisons and ralsely inflated metaphors, for instance, or by syntactical assistance. It is not the blunders that are of rensive; what offends us is the actual existence of these lines. (24)

This kind of poetry is intrinsically flawed:

"The end [purpose] of the eulogy of the ruler, that is, of an extreme political element in poetry, defies all political, psychological, or sociological explanations. . . the language of poetry refuses its services to anyone who uses it to immortalize the names of those exercising power. (26)

It is this irrational, non-analyzable element in poems which makes them so resistant to Marxist literary criticism. Enzensberger cites George Lukács, another rigure who appears orten in Das Wort, as an example of a Marxist critic who simply ignores for the most part poetry and concentrates on narrative fiction. Nor can such critics deal well with the question of $q u a l i t y$ in art: "Hence his predilection for the classics; this enables him to avoid the vexing question of the status of the work into which he is inquiring" ( 27 ). Such a critic writes only "from the standpoint of literary sociology" 
and is "blind to his subject and and sees only what lies at the surface" (27).

Literary criticism of this type abounds in Das Wort, as do lengthy articles about German writers like "Herwegh, Freiligrath, and Weerth," whose politics were correct for their time. Cultivation of the Kulturerbe is a priority - but with a slant.

Politics in this sense infuse Das Wort. And if, as Enzensberger asserts, eulogistic leader-worshiping politics render poetry illegitimate, so did das Wort surrender its literary legitimacy to the "higher" cause of eulogy of the Soviet Union and its leadership. Many of the pieces about the Soviet Union which will be examined in this thesis are very skillfully executed and exhibit many artistic qualities. Yet the unquestioning tone of prase of authority, no matter how well done, just does not seem appropriate in a journal which was claiming to be the heir of the Western European tradition of humanism and enlightenment.

It is demeaning to a very large number of German writers on the Left who suffered greatly for their beliefs to ascribe base motives to them. It will not be the purpose of this thesis to delve into the individual reasons why the contributors to Das Wort wrote as they did. However, a sense of the mood of the time, and some idea or how it was that such literature did seem perfectly appropriate to its writers and editors, can be gained by a detailed look at the political background of the journal, and by examining the image of the Soviet Union as portrayed in the pages of Das Wort. 


\section{NOTES TO CHAPTER I}

1 Das Wort: Literarisches Monatsheft. 11 Yols. (Berlin:

Rütting \& Moening, 1968). This is a "fotomechanischer Nachdruck" published in East Berlin. Yolume 11 is a "Registerband" which includes an extensive and useful afterword by Fritz Erpenbeck (Registerband: 5-18). A note explains that the reproductions are complete except for the covers (19). Pictures, tables and illustrations included in the originals are incorporated in the reproduction, in quite good quality.

2 Perhaps the most notable success of the entire United Front movement was the "mock trial" staged in London preceeding the Wazi trial of those accused of setting the Reichstag Building afire. See David Caute The Fellow-Travelers: A Postscript to the Enlightenment. See also Lion Feuchtwanger's "Second Brown Book of the Hitler Terror" published in conjunction with the trial.

3 "Poetry and politics," Critical Essays, ed. R. Grimm \& B. Armstrong. Trans. Michael Roloff (N.Y.: Continuum, 1982) 15-34. Enzensberger's essay, which makes a strong argument for political autonomy for writers, is all the more interesting in the light of his work, much of which might well be considered to be "political." 


\section{CHAPTER II}

\section{THE POLITICAL BACKGROUND}

"To learn from the Soviet Union is to learn to win" (Von der Sow jetunion lernen heibt siegen lernen' is a slogan heard many times over the last 40 years in the German Democratic Republic. It was repeated by Erich Honecker in his speech commemorating the Fortieth Anniversary of the roundation of the GDR, just days berore he was replaced as chairman of the Sozialistische Einheitspartei Deutschland (SED) and head of state. It is an irony of history that the SED should be following the lead of the Soviet Union in making this move, which ultimately, and quickly, led to the resignation of the entire SED leadership, a new name for the party (the Party of Democratic Socialism), legalization of alternate political parties and multi-party elections, and disavowal of the party's constitutionally guaranteed "leading role" (Führungsanspruch) in society. All these actions were set in motion by Soviet President Mikhail Gorbachov on the same occasion as Honecker's speech, October 7, 1989. Corbachov let drop the remark that "life itself punishes those who delay" and, more specifically, let it be known that the Soviet Union would under no circumstances use armed forces to suppress internal dissent in the countries of her erstwhile allies in Eastern Europe. The Soviet leader is supposed to have explicitly encouraged younger leaders such as Egon Krenz to remove Honecker (Ash 14). They 
learned, this one last time, from the Soviet Union. Alas, their victory was very short-lived. By the end of January 1990 both Honecker and Krenz, and many more, would not only have been removed from their posts in turn, but expelled from the party and arrested for good measure. The SED, the direct heir to the Kommunistische Partel Dertschlands (KPD), was well on its way to extinction.

The SED's lack of legitimacy in the eyes of the citizens of the GDR is to a large degree due to its unswerving fealty over the decades to the Communist Party of the Soviet Union (CPSU). Only during recent years has the Party attempted to follow an independent line - by resisting the lead provided by Mikhail Gorbachov and his policies of perestroyka and glasnost. The SED's close relationship to the CPSU has been a bedrock principle throughout its history. From its foundation on April 22, 1946, when the Sozialistische Partei Deutschland's in the Soviet Occupation Zone was united with the KPD, to Honecker's rinal oration, special ties to the homeland of Marxism-Leninism have been proclaimed. They are enshrined in article 6 of Honecker's 1974 constitution:

(2) Die Deutsche Demokratische Republik ist $\mathbf{f}$ ür immer und unwiderruflich mit der Union der Sozialistischen Sow jetrepubliken verbündet. Das enge und brüderliche Bündnis mit ihr garantiert dem Yolk der Deutschen Demokratischen Republik das weitere Voranschreiten aur dem Wege des Sozialismus und des Friedens. 2

The role played by the USSR in East Germany over the last forty years has been paramount, both through direct intervention and as a model to be emulated. That role did not begin on May 8 , 1945, however. It has a much longer history. The SED's predecessor, the Communist Party of Germany, had already become quite 
subservient to CPSU by the late 1920's. The German Communist writers in the 1930's who edited and contributed much which appeared in Das Wort lived and worked with the consequences of the KPD's development in the 1920's. Das Wort did not "toe the party line" simply because exile had driven its editors to take refuge in Moscow. Their presence in that city was a natural and consequential result of events during the previous decade. An understanding of those events is a prerequiste to understanding the role which Das Wort sought to play in the exile.

\section{THE COMINTERN AND THE GERMAN COMMUNISTS}

From the day of the establishment or Soviet power in Russia in October 1917, the very existence of an avowed Marxist-socialist state had a profound impact on the revolutionary left in Germany. At first this impact was mainly in the form of a great boost to the spirits of the beleaguered revolutionaries, and an encouragement to action. But soon, it took a more direct form as the Communist Internationale (Comintern) was founded on March 4, 1919. Representatives of 19 parties and groups from throughout the world had gathered in Moscow at the invitation of Vladimir Lenin (McKenzie 24). As might be expected, the Russians dominated the gathering. The German delegate, Hugo Eberlein, actually opposed the immediate foundation of a new Internationale. Rosa Luxemburg had apparently felt the new organization would too easily be subordinated to Moscow (Flechtheim 141). The German party preferred calling a new congress more representative of the Left as a whole, where a Third Socialist 
Internationale could be founded. In the event Eberlein was overridden by the other delegates and abstained. The First Congress of the "... III., kommunistische Internationle..." was proclaimed (Die Kommunistische Internationale 70). Despite initial reticence, the KPD was still the first non-Russian party to join the new organization (Flechtheim, 141).

An Executive Committee (the ECCI) was formed, led by Lenin, Trotzky, and Zinoviev. A pattern of influence and direct control by the CPSU was being established. During the civil war in Russia 1918-21, this control was very loose. But beginning with the New Economic Policy (NEP), proclaimed by Lenin at the 10th Congress of the CPSU in March 1921, direct intervention in the affairs of the foreign communist parties increased. This trend was especially evident for the KPD. Professor E.H.Carr states the case succinctly in the preface to his study of the Comintern:

In the present volume the affairs of the central organs of the Comintern were so closely intertwined with those of the German party that I have not found it necessary to devote a separate chapter to that party. (Carr viii)

Although the original goal of the Comintern was to promote the international collaboration of communist parties working for revolution in their countries, the influence and eventual direct control wielded by Moscow over these parties meant that practically they became organs of Soviet-Russian foreign policy. When the exigencies of national Russian foreign policy changed, the policy of the Comintern changed also, even when the new policy ran counter to requirements of the situation in a particular country. The leadership 
would either change its policy or, more commonly, be replaced. ${ }^{3}$ The type of party promoted by Lenin as the only one capable of leading the proletariat to victory was composed of a tiny, elite leadership which issued orders to the rest of the party. Party discipline meant following the party line issued from the top. The Comintern was in effect such a party, an international communist party, with the national parties the operating units and the ECCI in Moscow the headquarters.

At the time of the founding of the Comintern, hopes ran high for immediate revolution throughout the world. This was to be an international revolution, based on the model provided by "... der Bolschewismus als Vorbild der Taktik für alle. . . (Lenin, in Die Kommunistische Internationale 54) The basic idea was that spontaneous uprisings "from the streets", while possibly succeeding in overthrowing local regimes, would not create the dictatorship of the proletariat, the necessary prerequisite to the eventual development of true Communism. Only a communist party "of the new type", led by a dedicated and disciplined elite, could carry out a successful revolution. The Comintern would see to it that revolutions were carried out which would result in Soviet-style governments under their control.

McKenzie describes the development of Comintern policy for the international revolutionary movement. (McKenzie $47 \mathrm{ff}$.) In the First Congress, "bourgeois" democracy was absolutely repudiated. It was the political form by which capitalism exercssed its dictatorship over the proletariat ( 47 ). The question of how revolution was to be 
accomplished, and the role of the communist party, as well as that of the Soviet communist party, was always foremost in the deliberations of the Comintern congresses. As early as May 1920, with the Russo-Polish war phase of the Civil War still in progress, Lenin had come down strongly aganst those elements supporting premature, spontaneous revolution, as he saw it, in his aggressive brochure "Left-Wing" Communism, an Infantile Disonder (McKenzie 48). Lenin did not consider the proletariat politically mature enough to lead a successful revolution, let alone run a modern state. That was to be the job of the "cadre" party. The leadership would determine the party line, and the rest of the party would not deviate from that line. The stress was on practical activities which would lead to revolution and victory. Abstract ideological considertions would not stand in the way of effective tactics. It is a doctrine of revolutionary Realpolitik. Communists were not to eschew working in trade unions and in parliaments, just because they were institutions of a rotten society (McKenzie 48). Communist participation did not mean approval. Any means were acceptable as long as they contributed to the ultimate victory of the proletariat and its vanguard party.

A critical prerequisite to the effectiveness of communist tactics had to be party discipline, hewing to the party line as laid down by the leadership. This concept, called partijnost in Russian, and Parteilichkeit by the Germans, was given sacred cachet by Lenin. 4 Under Stalin, it would come to mean simply supporting the CPSU and the Soviet Union without reservation, in all circumstances. Those who 
rejected the leading role of the party in favor of a nebulous "democracy" were starry-eyed idealists, "infantile" in Lenin's choice word, and harmed the cause of the revolution.

The revolutionary wave in Europe soon receded. The defeat of Bolshevik revolutions in Hungary and Germany, and railure in the war with Poland, exacerbated the diplomatic isolation of the USSR. In 1921 it was not at all clear that the new government in Russia would ultimately survive. Trotzky and the internationalist-minded Bolsheviks felt that only a revolution in Germany would rescue the Russian revolution. But after failed German risings in 1921 and 1923 , a period of retrenchement was called for, both internally and externally. Lenin's NEP marked the beginning of that period. Stalin's doctrine of "socialism in one country" was the international version of the new policy. The survival and development of the only Socialist government actually in control of a major state was the prime requirement for the eventual victory of communism the world over.

At first, stressing support for the Soviet Union was essentially a tactical maneuver. The primary goal was still world revolution. In fact, the expected revolutions in the far more advanced countries of Europe were given preeminence for the world struggle. McKenzie cites Trotzky's oration before the Third Congress of the Comintern:

Yes, Comrades, we have erected in our country the bulwark of the world revolution. Our country is still very backward, still very barbaric. - . But we are defending this bulwark of the world revolution, since at the given moment there is no other in the world. When another stronghold is erected in France or Germany, then the one in Russia will lose nine-tenths of its significance; and we shall then go to you in Europe to defend this other and more important stronghold. Finally, Comrades, it is sheer absurdity to believe that we deem this Russian stronghold of the Revolution to be the center of the world. (McKenzie 54) 
Only one year later, in 1922, the Fourth Congress passed a resolution calling for ". - workers in other countries "to fight for the Soviet Union" (McKenzie 54). The following year, a program of "Bolshevization" of the Comintern was promulgated (McKenzie 55). The use of the Russian word here is symptomatic. Subsequent congresses and plenums of the ECCI elaborated this program. Foreign parties were to hew more rigidly to the good example set by the CPSU in their revolutionary activities. The practical effect (and, putatively, the intention) was to gather more control into the hands of the Russian Communist party.

Centralizing control in the hands of the Comintern continued throughout the 1920's, and was an established ract by the end of the decade. It was the result of two factors: the waning revolutionary tide in Europe and the internecine power struggles within the CPSU which led to Trotzky's banishment and Stalin's accession to supreme dictatorship after the death of Lenin.

1923 was a year of upheaval and chaos in Germany. During that year occurred the worst of the Inflation, the French occupation of the Ruhr, the declaration of separatist republics in the Rhineland and Bavaria, and a communist-socialist uprising in Saxony, encouraged by Moscow (Kennan, Soviet Foneign Policy 49). These events contributed to the belief that the revolution was at hand. Yet the Weimar Republic survived. The Soviet Union had already in ract established normal diplomatic relations with the German republic and signed with them a cooperation agreement at Rapallo on Easter Sunday, 1922. The pariah states of Europe had been driven 
together, in an effort to gain maneuvering room against France and England (Kennan, Russia and the West 208). A basic problem which was to dog the Soviets in their international relations was evident here. Kennan writes:

There was thus established, at this early date, that ambiguity and contradictoriness of Soviet policy which has endured to the present day : the combination of the doctrine or co-existence - the claim, that is, to the right to have normal outward relations with capitalist countries - with the most determined effort behind the scenes to destroy the Western governments and the social and political systems supporting them. (Kennan, Russia 166)

This ambiguity of Soviet intentions was to plague efforts by the Comintern in the 1930's to gather the support or Western intellectuals into common front to oppose the Nazis.

In the 1920's and into the ' $30^{\prime}$ 's, the Comintern continued to work for eventual revolution in Germany and elsewhere. Orficial Soviet foreign relations, however, conducted by the People's Commissariat for Foreign Affairs (Narkomindel), promoted political and trade relations with the capitalist states. And the Soviet Union had already begun clandestine military collaboration with Germany as early as 1920 (Kennan, Soviet 40).

The death of Lenin in January 1924 unleashed the power struggles through which brought Joseph Vissarionovich Stalin gained control over most of the "old Euard" of the Bolshevik movement. Trotzky was driven from the party and, in 1928, from the country. With him went any concept or internationalism which might leave the Soviet union playing second fiddle to some other party. Stalin, although ethnically a Georgian, effectively promoted Great Russian nationalism in Soviet guise. The mechanisms which had been built up 
to promote international revolution were now to be used to secure and advance "socialism in one country," the Soviet Union.

Stalin turned his attention inward, abolishing the MEP in 1928 and promulgating the first Five-Year Plan and the industrialization of backward Russia, collectivization of agriculture in the early $1930^{\prime}$ s, and the establishment of a pervasive central bureaucracy subservient to him alone.

In the KPD, ideological disputes and leadership changes which racked the party throughout the early 1920's did more than copy the fights within the inner circles of the CPSU. They were actually part of those struggles. Sometimes the personnel was even identical. Karl Radek, who had participated in the founding of the KPD and had an independent role in the German communist movement, was also an old Bolshevik. He became the scapegoat following the failures of 1923.5 But the defeat of the left wing of the KPD was only part of the battle taking place among Lenin's cohorts following his death. On the one side were Trotzky and Radek and like-minded "internationalists", still clinging to ideas of world revolution. Against them were ranged Zinoviev, Bukharin, and, of course, Stalin. 6 It is not appropriate in this study of one facet of German literature in exile in the 1930's to go into these matters in any detail. Surfice it to say that by the end of the 1920's the leadership of the KPD had been brought fully into line. It was entirely subservient to the leading group of the Soviet party. It is also worthy of note that the name of the man who was to play the key role during the first two decades of the German Democratic Republic now appears in the accounts of this period: 
Walter Ulbricht. He was an advocate of the policy of "Bolshevization" of the KPD, and declared that "...bei allen Auseinandersetzungen hat die Komintern das entscheidende Wort" ( $Z$ ur Geschichte der DDR 10). Such was the mentality of the party functionaries who replaced the heirs of Rosa Luxemberg and Karl Liebknecht

\section{GERMAN LITERATURE AND THE RUSSIAN REVOLUTION}

The influence of the Russian Revolution extended into every area of activity of the German Communists. Revolution was to be total, to embrace all spheres of human society. Culture in particular was to play a central role both as a means to promote the revolution among the population and as something which itself had to undergo a revolutionary revision. The arts were to be drafted into the strugele which would bring about the political collapse of bourgeois Germany and to radically transform the thinking and the perceptions of the people. The Bolshevik revolution would provide the model in this, as in other matters.

But in the Soviet Union itself, where the upheavals of the revolution and War Communism had given way to a modicum of stability in the form of the NEP program, the nature and role of art in the development of socialism were matters of strident and of ten brutal contention. The central ideological dispute concerned the function artists were to have in the new society: were they to confine themselves to depicting and interpreting the world around them as they individually perceived it, or were they to actively engage in "raising the consciousness" of their audience, in 
transforming the world into something new and better. Infusing these questions was an even more fundamental dichotomy of views concerning the very nature of the the Revolution itself. Could a new society be created virtually from scratch, by throwing out in one fell swoop the entire Western heritage of art and culture and proclaiming a new proletarian culture to replace that which had come before? The logic of this view would mean that centuries of culture would simply have to be discarded, the "garbage of history." Alternatively, the new culture could develop out of the old, with considerable pushing in the right direction, of course. This view would leave a role for those elements of the art and literature of previous generations which were deemed progressive. And the right-thinking writers, artists and intellectuals of the previous era who were still active would also have a role to play in this model of the transformation of society.

During the Civil War the party leadership devoted little time or energy to such questions, permitting by default great latitude to the artists and writers to work out a new art - and to attack enemies. True, from the very early days of the new government, the Party made clear its intent to administer art (Heller 191ff.). They were simply unable to do so at this time. In these chaotic and intellecturlly fervid early years, groups and artistic movements came and went: the Serapion Brethren, Opoyaz (Society for the Study of Literary Language), Formalists, Nichevoki ("Mothingists"), Constructivists, LEF (Left Front of Art) and New LEF, Proletcult, RAPP (Russian Association of Proletarian Writers), all squabbled among themselves to define, and capture, the true revolutionary 
art. 7 By the late Twenties, questions of art and culture had become part and parcel of the ideological war by which Stalin fought for and achieved hegemony over the party and the state. Particulary with the end of the MEP and the proclamation of the First Five-Year Plan, the Party's attitude toward art took more concrete form. The form of art, which is usually the subject of disputes about aesthetics, was of little significance. What counted was the content. And, after 1928 , the content was to be the construction of a modern and powerful industrial state in Russia. Art must contribute to "Socialist Construction," as Stalin's plan to compress generations or development in to years came to be called.

What applied to art in general was particularly true of literature, since the written word was considered the most economical means of telling people what they should be doing and thinking. Writers and poets adopted the imagery of industrialization for their work, likening artistic production to that of industry. Mayakovsky declared: "I feel like a Soviet factory" (Heller, 218). The effectiveness of the material produced by such literary-industrial production was limited by the very high rate of illiteracy. The Bolsheviks were for the most part highly literate men who considered the word an extremely powerful weapon in the right transform their society. Rassing literacy was the centerpiece of Soviet educational policy from the first days of Soviet power. Mikhail Heller writes of this period, quoting Lenin: 
Immediately arter the October revolution the "anti-literacay front" was opened, alongside the military and economic front. The goal was not so much to teach the illiterates how to read and write as to teach them to think correctly. "The illiterate," Lenin explained, "remains outside of politics, and that is why he must be taught the alphabet. Without this there can be no politics." (Heller 174)

The word, then, was to be mobilized to carry out the policies of the party. Writers were not to be above the demands of partijnost. We will see how this utilitarian view of literature was realized by the German literati in exil in their attempt to mobilize a united cultural front against the Mazis.

In Germany, the situation differed considerably from that in Russia. The revolution had failed and the party was in no position to dictate artistic standards to any one, not even its own members, until well into the decade. During the rirst half of the Twenties the party was occupied with internecine dispute. Many of the writers who were to figure so prominently in Soviet exile and in the rirst decades of the GDR make their appearance at this time: Johannes $R$. Becher, Erich Weinert, Friedrich Wolf, Alexander Abusch, Egon Erwin Kisch, Andor Gabor, F.C.Weiskopr, and Alfred Kurella, to mention only a rew. 8 They were all very active in the polemics of the twenties, and took the correct side in the struggle which erupted in the party leadership when the Comintern instituted a policy of "Bolshevization" of the KPD, in line with developments in Russia. ${ }^{8}$ The dispute resulted in the utter defeat and banishment of the Luxemburg-Liebknecht "left-wing" of the party by Comintern loyalists headed by Ernst Thälmann and Wilhelm Pieck (Zammito 78 ). It was a defeat for Trotzky and Internationalism as well. By the latter half of the 
Twenties the leadership of the party had driven out the "ultra-Lert" and achieved the centralized control and party discipline which was the real purpose of Bolshevization. The overt influence and direction exercised by Moscow over the KPD now became the dominant reature of the Party. Already a faction of the Party which did not wish to be subservient to the Russians had split from the KPD in $1920.10 \mathrm{BY}$ 1925 victory was complete: ". . the 'Bolshevization' process culminated in general with the replacement of ideological leaders of independent stature by apparatchiks, .. ." (Zammito 78). The chief apparatchik among the German writers was the poet Johannes $R$. Becher, who did not hesitate to aver his loyalty to the Comintern and the Soviet Union: ". . Die Große Sozialistische Oktoberrevolution war die eigentliche Geburtsstunde unserer Literatur" ( $Z$ ur Tradition 1: 1). Becher took part in the I. International Conference of Proletarian and Revolutionary Writers in Moscow in 1927.11 Inspired by that event, the Bund proletarisch-revolutionarer Schriftssteller (BPRS), based on the model of the RAPP in the Soviet Union, was founded by him the following year. Such an organization typifies the trend toward bureacratic centralism which was now so marked in Stalin's Russia. In was a mechanism by which Parteilichkeit would be forced upon the German Communist writers (Zammito 82 ).

Following the post-NEP Soviet line that art and politics not only mixed, but were one in the same, the Communist writers merged political and literary work. Literature was seen as medium of expression very well suited to communist purposes. Especially in its 
polemical and critical mode, the word made a difrerence.

To demonstrate that this use of literature had always been an integral part of its nature - and to establish the historical kudos or their own literary activities - historical antecedents were cited. Friedrich Wolf's 1928 tract "Die Kunst als Waffe!" is a succinct, lively, provocative and entertaining exposition of this viewpoint $(Z u r$ Tradition 1: 57-76). In purple prose replete with italics and exclamation marks, Wolf cites Zola (J'accuse... i), Tolstoy ("Ich kann nicht schweigen!", an empassioned protest aganst the war with Japan), and Harriet Beecher-Stowe among foreign antecedents of this polemical traditon. In Cermany, he begins around the year 1200, with Walther von der Vogelweide's poetry about the power-struggle between Pope and Emperor. (Zur Tradition 1: 60). It is a exclamatory tour de force summary of all of Cerman literature. Wolf finds writers in every generation who merged politics with literature. A passage about Heinrich von Kleist's famous novella Michael Kohlhazs provides a taste or Woll's prose:

Einen Kerl dieses Volkes aber, diesen Michael Kohlhaas, hat nach 200 Jahren der Dichter Kleist als großes Sinnbild herausgehoben. In dieser seiner erdhaftesten Arbeit hat der Dichter nicht, wie damals üblich, die Fürsten- und Religionskämpre ins Zentrum gerückt, sondern den Cerechtigkeitskampf und den Untergang des gemeinen Mannes. Ihm kam es darauf an, die gepeitschte, verhöhnte, rechtlose Kreatur, diesen Typ des... (Zur Tradition 1: 65)

Wolf's conclusion is a poem asserting the word's power: "Jedes Wort ist Gefahr! / Denn Wort ist Warfe! / Worte sind Hämmer, . . / Worte sind Fackeln ..." and "Kunst ist nicht Dunst noch Bildungsgegaffe. . . Kunst ist Waffe!" (Zur Tradition 1: 75 ). 
Wolf's piece is evocative of both the style and the content of much of the work of the Communist writers, and it demonstrates their continual striving to find legitimization in historical antecedent. It is tupical of the kind of work which Das Wort was to feature so prominently some years later.

The German communist writers did not merely accede to the Erowth of Soviet influence and direction in the KPD and the BPRS. They welcomed it and promoted it. In speeches at conferences and in articles in journals, they lamented insufficient cooperation with their writer comrades in the USSR and promoted amalgamation, to the maximum extent allowed by geography and language, of the activities of German communist writers with those of the Soviets. S.Robert bemoans: "Leider ist die Verbindung unserer deutschen Schriftsteller zu den russischen sehr schwach" (Zur Tradition 1: 106-107).

Primarily because "nicht alle unsere Schrftsteller die Möglichkeit haben, nach Sow jetrußland $2 u$ fahren" (107). According to Robert, the recently founded BPRS has allowed the writers to stand "auf der Platform des Klassenkampfes," and now they are ready ". . mit Wort und Tat den ersten Arbeiterstaat der Welt, die Sow jetunion, zu unterstützen" (108). This was published in September 1928, long before Hitler and the neal threat to the Souset Union.

Johannes Becher waxes sentimental in his conclusion to a long oration before the Kharkov conference of proletarian-revolutionary writers in 1931:

"Lang ist der Weg nach Tipperary, aber dort lebt mein Herz" heißt es in einem englischen Soldatenlied. Lang und schwer ist unser Weg - in voller Freiheit aber können unsere Herzen bis jetzt nur hier in der Sow jetunion schlagen, in dem Lande der Diktatur des Proletariats und des Aurbaus des Sozialismus.12 
The gist of this long speech is that the Soviet Union, as the only real proletarian state in the world, is threatened by war waged by the capitalists. It is the primary duty of revolutionary writers the world over to do all in their power to thwart those plans. Following the pattern set for the party by Bolshevization, the most effective means to do so is to organize literature: "Die Organisierung unserer Literatur im Hinblick auf die drohende Kriegsgefahr ist natürlich ganz besonders wichtig" (294). The BPRS, and its international manifestation, the IURS (Internationale Vereinigung revolutionäner Schriftsteller), is the means to achieve that organization. The importance ascribed here to administrative means is indicative of the bureacratic mentality which was now totally dominant among the German KPD writers. And well before exil drove much of the KPD leadership and many of the writers to actual residence in the Soviet Union, they were committed by "Wort und Tat" to the Soviet Union and its leadership. If the articles and stories which appeared in Das Wort are unabashedly and without reservation positive in their attitude to the Soviet Union, it cannot be said that this was only because the journal was published there, and the editors lived there, or that the the Popular Front policy required this stance. The pattern of 100 percent support for the USSR had been established long before, and in Germany and elsewhere. 
THE POPULAR FRONT AND GERMAN SOUIET EXILE

Following a period of relative stability in the mid 1920's, the end of the decade brought crisis after crisis to the wobbly institutions of the Weimar Republic. Never wholly supported by more than minority of the populace, rising economic woes and increasing political extremism weakened the Republic fatally. Among those who contributed materially to the destruction of Germany's first attempt at real democracy was the German Communist Party. Their attitude had been consistently and entirely hostile to the Republic since its inception. The first generation of KPD leaders wanted immediate revolution and the establishment of a proletarian dictatorship. Risings which they either fomented or tagged along with in 1919, 1921, and 1923 forced the German Social Democrats to call upon the right-wing forces of the army to save the Republic. The legitimacy of German democracy was compromised at the outset.

The Communists considered the Social Democrats merely a last clever mechanism by which the capitalists were striving to maintain their real power. They called the SPD "Social Fascists" and made no particular differentiation between them and the Nazis (Flechtheim 2695. ). In fact, they were mone dangerous than the Nazis, because they appealed to the industrial workers, whose support the Communists considered rightfully theirs. The Social Democrats were "traitors" to the class struggle and deserved only destruction.

The policy of unremitting hostility to the Social Democrats did not change after Moscow, through the Comintern, took over effective 
leadership of the party. The Soviets did not wish to see the SPD, in coalition with the Communsits, gain secure power in Germany. The Communists were useful in preventing that happening. Nor was Moscow interested in seeing the KPD take over on its own. George F. Kennan describes Stalin's attitude to the KPD in this fashion:

He had no particular desire that the German Communists should prosper, and particulary not that they should prosper to the point where they themselves could take power in Germany: he knew that they would then be uncontrollable. ${ }^{13}$

This KPD policy did not waiver as political order and civility self-destructed in Germany. The party contributed to the growing chaos with its own storm-troopers, who would brawl with Social Democrats as readily as with Nazis. True, the official pronouncements of the Comintern and the KPD spoke of "United Front" with the Social Democratic workers. But this was to be special kind of United Front, one "from below," as the party ideologues termed it (Die Kommunistische Internationle 330). The Social Democrats and unattached workers would be permitted to follow the directives of the KPD, but nominally no cooperation with the SPD leadership would be permitted. Later, after the Nazis had seized power in Germany, the term "United Front," or more commonly, the "Popular Front" (Volksfront), would apply to the policy calling for support and cooperation with anyone who was against the Nazis. But no matter what the of ficial policy line became, in Germany or the USSR, the Communists never really changed their attitude to the SPD. That is because they actually had it right: Social Democracy did present the greatest threat to their claim to primacy of the political Left. Unfortunately for them and for the Social Democrats - and indeed 
for the world - the KPD's unmitigated animosity toward Social Democracy contributed materially to the rise of the Mazis. 14

Battered by growing extremism, with the political center shattered by vicious assaults from right and left, the Weimar Republic expired on January 30, 1933, when Adolf Hitler assumed the office of Reichskanzler. The absolute misunderstanding and doctrinal obtuseness of the German Communists to the threat posed by the Nazis is manifest in their initial reactions to the new situation. They thought nothing had changed. By their lights, Hitler was just another stooge of the finance capitalists. Suggestions by the SPD to work together to defeat Hitler in the upcoming elections were dismissed by Walter Ulbricht as "Wahlgeschät (Duhnke 64). They denied that a "Systemwechsel" had occured and rejected out of hand a reanalysis of their policies (Duhnke 63 ). They were brought to a rude awakening on the night of 27 February 1933: the Reichstag Building in Berlin was set ablaze. The Reichstagbrand was used as a pretext to round up the Communists and suspend the Constitution. 15 The exile had begun.

The Communist leaders and intellectuals who were not picked up immediately went into hiding, and many fled the country at the first opportunity. Some were killed outright, while others were to die later, along with their erstwhile bogeymen, the Social Democrats. Ernst Thälmann, the hard-drinking genuine proletarian who was the nominal leader of the KPD, was arrested. He was never released and 
later died in camp, achleving martyr status.16 Some, like Willi Bredel, later to be the first editor of Das Wort, spent considerable time in a concentration camp, but were released and subsequently fled the country. It was quite natural for the German communists to want to escape to the Soviet Union, and many did, though not without difficulties. Perhaps the most remarkable thing about the fate of these revolutionaries is how many did not end up in that country, and the great obstacles many would encounter from Soviet officials over the years in obtanning entry visas and residence permits. These facts are perhaps not so incomprehensible if considered in the light of the Comintern's - and Stalin's - true attitude toward them. The Communists had had a role to play for Soviet purposes in Germany, albeit a false one, seen in retrospect. What exactly it is that they could be doing in Moscow was not as yet so obvious.

Initial Soviet reaction to the Mazi seizure of power in Germany was. - business as usual. Kennan sums up Stalin's reactions:

The same reason that had made him blind to the danger of Hitler's rise to power in the first place now continued to obscure from his eyes the meaning of the final establishment or Mazi rule. He was still unable to recognize the revolutionary nature of the Mazi movement. Because it had no clear class basis, distinguishable from that of other bourgeois parties, he could not see its triumph as a revolutionary development. The slaughter of the German Communists by the Gestapo left him apparently unmoved. Repeatedly, he caused Hitler to be assured that this constituted no reason why good relations should not prevail between the two countries. (Kennan, Russia 296)

It soon became evident, however, that something more significant had occured than just a reshurfle by capitalist puppet masters. For one thing, Hitler had shown that he was not going to 
tolerate "two-raced" Soviet policy: of ficial cordiality and cooperation with simultaneous sub rosa revolutionary agitation by the Comintern. The ambiguity in the relations which characterized the Soviet government's dealings with the West would not be allowed to continue with a country whose government was now every bit as duplicitous as his own. Diplomatic relations began to deteriorate, and the Soviet press was soon running articles hostile to German policy, especially that of rearmament (Carr 98). Both sides rejected a total breakdown, althought relations continued to slide inexorably throughout 1933 and 1934.

The policy of the Comintern reflected that of the CPSU. In 1933, Fascism was still considered a manifestation of the shenanigans of the tycoons, the "open terrorist dictatorship of the most chauvinistic and most imperialistic elements of finance capital" (Mckenzie 144 ). The Comintern ideologues moved slowly from this view. Nevertheless, events forced them to develope new policy, as did the Soviet government itself. German racist propaganda, talk of "Lebensraum" in the Ukraine, and a ten-year non-agression pact which Hitler signed with Poland in January 1934, all served to make Stalin realize that Hitler, and not France and England, presented an actual military threat to his security (Kennan, Russia 300).

$$
\text { stalin. }
$$

1934 also saw him faced with internal political difficulties. It seems that in this year he took the decision to solve once and for all the problem of rivals within the party bureaucracy, especially among the "Old Bolsheviks." The assassination of Sergey Kirov, the popular and reformist-minded party boss of Leningrad, in December of that 
year, ushered in that bizarre and grusome period of Soviet history know as the Great Purges. To try to neutalize the danger presented by Hitler and to give him more freedom of action for internal moves, Stalin initiated on the diplomatic level the concept of collective security. He hoped that he could direct Hitler's predatory attentions to the West, and that his offers of cooperation would give the weak-knee'ed democracies a little backbone.

The Comintern was directed to mobilize and promote support among sympathizers in the West, and to permit greater collabortation with social democratic and liberal sympathizers in Western intellectual circles (Pike German Writers 80 ). This policy was called the United, or Popular Front (Volksfront), revising an old concept for different duty. In France, the new policy led to spectacular early political success. The Communists and socialists collaborated to combat a growing tide of right-wing activity and eventually brought the Front Populaine to power (Pike 78). By contrast, in Germany the KPD never did rid itself of its old enmity to the Social Democrats. It continued its attacks on the SPD throughout the entire Nazi period, if in public a somewhat less virulent tone (Carr 142). The Communists never really dropped the idea that Nazism was merely an extreme form of imperialistic capitalism. They could never bring themselves to accept that Hitler actually was popular among the workers of Germany because of his reversal of the hated Versailles Treaty and his making Germany feared again among the nations of Europe. The Party was always saying that Kazism was in a crisis and on the verge of collapse, even as Hitler steamrolled country after country. The 
Popular Front policy was seen as new tactic required by changed circumstances, a change of emphasis, not a real change of long-term Boals.

It was on the cultural level that the Popular front policy had its greatest impact. Indeed, in this sphere the policy had in effect already been in action since shortly after the Bolshevik Revolution because of the inderatigable energy and inventiveness of Willi Münzenberg. Since 1921, he and his organization, International Worker's Relief (usually termed IAH from the German, or MRP from the Russian) had worked incessantly - and successfully - to garner support for the Soviet Union among the leading intellectual circles in the West. 17 For nearly two decades Münzenberg traveled to and fro throughout Europe arranging meetings, conferences, and congresses of every variety for all the good causes of the day. Primarily his function had been to promote the Soviet Union, to encourage sympathizers in the West to pressure their governments to moderate their attitudes to the new state, to create a positive image of developments in the USSR, and to convince people that the policies of the Soviet government, despite unavoidable harshness, were in the end directed to noble ends and a bright future. Remarkably, despite doctrinal and policy twists and turns which often put the communist parties of the various countries greatly at odds with the values and interests of the liberals and rellow-travelers who were his clientel, Münzenberg managed to disassociate himself publically from the of ficial Communists and continue not only to avold his own destruction at their hands, but to actually convince many important 
artists and writers and leaders of public opinion in the West that somehow the Soviet Union was not to be held to account for the pernicious activities of the communists in their own countries. The inglorious denouement to this man's colorful career might serve as an epitaph to this whole period. Following the Russo- Cerman Non-Agression Pact, his campaign of pro-Soviet anti-Hazi agitation in what was left of rree Europe quite naturally disintegrated. He refused to toe the new party line, and fell out seriously with the Comintern. He avoided returning to Moscow for "consultations." The invasion of France in 1940 found him rleeing for the Swiss border. He never made it. He was round hanging in a tree, murdered in a French rorest by parties unknown. Whether it was the Nazis or the Soviet secret police, no one can say.

The sad conclusion to Münzenberg's career in no way detracts from the considerable services he had performed for the Communists during the many years when they were caught up in sectarian in-righting and ranatical rejection of the liberal West. He had built up a small but infuential group of supporters for the soviet Union. These people came to be called fellow-travelers, a term that for their detractors was one of derision, but they carried it with something approaching deriant pride. The term is Russian in origin (poputniki). It was used in the early days of the Revolution to refer to those writers and intellectuals who were of bourgeois background and had begun their careers before the revolution, but chose not to emigrate. They supported the revolution even though they had not been revolutionaries. Among them were some of the real 
stars of the first generation of Soviet writers. ${ }^{18}$ Maxim Gorky belongs to this group, even though he has come to be an icon of Soviet literary historiography. The proper attitude to be adopted to the fellow-travelers was one of the issues at dispute among the Bolshevik ideologues, especially in the period after the NEP, when undiluted partijnost became the order of the day. At any rate, Willi Münzenberg had continued to curry the support of such prominenti as were amenable to his tireless organizational and publicistic activities. Theodore Dreiser, George Bernard Shaw, Anatole France, Henri Barbusse, Heinrich Mann, Lion Feuchtwanger, André Gide, Ernst Toller, and Alfred Döblin are some of the more notable names Münzenberg was able to collect in support of his causes - and that of supporting the Soviet Union.

In line with the Popular Front campaign launched of ricially by the Comintern in 1935, suitable employment for the German Communist writers now in Soviet exile had been found: the promotion of the Popular Front in the large exile Community scattered throughout Europe and the rest of the world. The spadework for them had been done long ago by Münzenberg and his MRP. 19

The task which the German Communist writers in Soviet exile were given was to promote the new line in the West among German-speaking persons of influence wherever they could be found. These sympathizers were then to use their influence to cause their governments to adopt policies favorable to the United Front idea. The idea was a simple one, and one whose essential correctness was hardly to be denied as the Thirties wore on: that Nazism meant war, and that 
all right-thinking people must band together to stop this peril, no matter what differences separated them otherwise.

A powerful idea, then, one which could and did attract many thousands of persons to fight against the growing Nazi menace, by encouraging their governments to rearm, to resist German diplomatic blandishments and bullying, or by acutally fighting, as many did in Spain. Yet in the end the policy failed. How could the Popular Front, an idea which seems in the retrospect of World War II and all that has followed, to have been such natural response to Hitler, actually have had so little efrect? The Popular Front was doomed from the beginning by the fact that in the end it came down to a matter of supporting the Soviet Union in all its activities and all its policies, both internal and external, in its relations with all countries and not just Germany, no matter what those policies were. The concept of Parteilichkeit for the Soviet Union was applied to a policy, and to a public which in the end would have to reject the concept and, tragically, the policy.

The Popular Front policy was carried out to large extent from Moscow, by the Comintern, an organization under Soviet control, for Soviet interests. And Soviet interests were to see to it that the Western democracies went to war with Nazi Germany, preferably without involving the Soviet Union. When it became clear to Stalin that the policy had failed, he turned to a new one: a modus vivendi with Hitler. In the process he abandoned all those who had committed themselves to the Popular Front. 
For the Communist writers and the fellow-traveler cohorts who helped them, however, their job was clear, and they carried it out with skill a verve which has not lost its power and attraction over the years. Much of the best work carried out by these writers in their lost cause can be seen in the pages of Das Wort. This journal was the literary mouthpiece of the German exile Popular Front. In it can be seen the strengths, the weaknesses, and the anomalies of the policy. It was one of the powerful weapons by which the Popular Front, and its associated complex of causes and topics, was given maximum public viewing among the German writers in exile. 


\section{NOTES TO CHAPTER II}

1 Quoted in Timothy Garton Ash, "The German Revolution," (The New York Review of Books, 21 Dec. 1989) 14. Ash is a prolific contributer to both popular and academic publications, covering primarily Germany and Eastern Europe.

2 Friedrich-Ebert Stiftung, Honeckers Verfassung (Bonn: Verlag Neue Gesellschaft GmbH, 1981) 10. Page a6 of the New York Times of February 5,1990, features a foto of demonstrators in Moscow carrying placards displaying a large number "6" crossed out. The very same Article in the Soviet Constitution as in Honecker's declares the Communist Party the "leading and guiding force" in society.

3 E.H. Carr's book provides an exhaustive account of the activities of the Comintern within the various national movements. Die Kommunistische Interntionale, the "orficial" history of the Comintern produced by the Central Committee of the CPSU, is a good source of original documents. Its view of events (as of 1970) is more userul as historical evidence rather than reliable interpretation.

4 The term defies translation into English. "Partisanship" may come closest, but fails entirely to convey the requirement of unquestioning adherence to direction from above. Parteilichkeit is meant to be an exact equivalent for the German Communists of the partijnost demanded of members of the CPSU. It meant far more that merely taking sides in an issue: it required an active role in the struggle to bring the party to leadership in your country.

Extending this idea to non-party sympathizers was part of the same process which came to demand of Communists and rellow-travelers the world over support for all Soviet activities.

5 For Radek's role in the founding of the KPD, see Kennan, Russia and the West $157 \mathrm{ff}$. For the shake-up in Moscow following the failure of the "October Action" in Saxony, see Flechtheim 191.

B The literature covering this period of Soviet history is massive. Perhaps one of the best studies, now a classic, is Leonard Schapiro's The Communist Party of the Soviet Union. For a Soviet revisionist view, see Roy Meduedev's Let $\mathrm{H}$ istory Judge. Revised and Expanded Edition.

7 Max Hayward, "Russian Literature in the Soviet Period", in Paticia Blake, ed., Writers in Russia 1917-1978 48-83. This is a lively and enlightening overview of the whole period of Soviet literature which I highly recommend to provide a quick but by no means superficial look at the sub ject. A more thorough textbook approach can be found in Marc Slonim, Soviet Russian Literature: Writers and Problems. 
8 These writers all contributed to Das Wort. Excerpts or short works by them are also cited in the table of contents of Volume One of Zur Tradition der sozialistischen Literatur 1926-1949, a massive four-volume collection of material deemed properly socialist by the GDR's Academy of Arts. An attempt to establish legitimacy by sheer volume, it is one of those oeuvres typical of the communist world which literary scholars have trouble classifying as primary or secondary literature. A revealing East German view of Alexander Abusch and the East German - Soviet Union connection can be found in Rolf Richter's "Der Kulturpolitiker Alexander Abusch und die Sow jetunion."

9 An excellent account of this period is John H. Zammito The Great Debate: 'Bolshevism' and the Literary Left in Germany, 1917-1930. Zammito concentrates on the intimate connection between ideology and culture which came to dominate the activities of the lertist intellectuals in Germany during this period.

10 They formed their own party, the Kommunistische Arbeiterpartei Deutschlands (KAPD) (Zammito 75 ).

11 See Zur Tradition 1: 93-95 for Becher's Referat before that assembly.

12 "Die Kriegsgerahr und die Aurgaben der revolutionaren Schriftsteller, Zur Tradition 1: 272-308(308).

13 Kennan ascribes the KPD's unwavering hostility to the SPD to Stalin's fear that if the Social Democrats gained too much power in Germany, they would turn the country toward France and England and away from the policy of loose cooperation with the USSR begun at Rapallo (Russia and the West 287).

14 See Kennan Russia and the West 290 for a discussion of the extent of the KPD's complicity in the disintegration of the Weimar Republic.

15 Lion Feuchtwanger collaborated with Georgi Dimitrov, later chief of the Comintern, and a defendant at the Mazi trial, to write "The Second Brown Book of the Hitler Terror" about the Reichstag fire trial. It is probably the most successful effort of the Popular Front propagandists.

16 Wilhelm Pieck and Walther ulbricht now assumed titurar leadership of the party, which they had already been running $d e$ facto for some time.

17 David Pike's account of Münzenberg's activities in Chapter 2 of his Germon Writers in Soviet Exile, entitled "The Literary International" ( $23 f f$.$) is excellent. Also see David Caute's The$ Fellow-Travellers: a Postscript to the Enlightenment 55-58 \& $132-137$. 
18 It may be convincingly argued, of course, that these were not Soviet writers at all, but this thesis is not the place for such a discussion.

18 See Pike Writers 89r. for Münzenberg's role in the Popular Front. 


\section{CHAPTER III}

\section{DAS WORT: CHILD OF THE POPULAR FRONT}

\section{THE LITERARY JOURNAL IN THE STRUGGLE AGAINST FASCISM}

Das Wort is a literary journal with a specific political objective: the dissemination and popularization of the Popular Front idea. Das Wort is a tendentious journal, which is one with a fairly specific cause or program which the journal intends to promote. Although Das Wort was touted as a to be a forum for debate as well as a place where original literature could appear, the correct attitude to most questions "discussed" in the pages of the journal were generally assumed to be known to the readers as well as the writers. Informed discussion and dispute, civilized debate and the discovery of truth through Socratic dialogue, these things are the heritage of the liberal Enlightenment. Articles which approach debate can be found in Das Wort, but tend to be concerned mostly with fairly esoteric matters of aesthetics and theory. The famous "Expressionism Debate" is an example. A strong political undercurrent ran through this debate, and the last word was reserved for a writer whose opinion was orthodox: that is to say, matched the current Soviet party line on the matter. 1

Far more common than debate in the pages of Das Wort is the impassioned plea, the outraged sense of right, the unabashed acceptance or orthodox authority and ecstatic outbursts of 
enthusiasm and praise. This is a gitprop, polemical literature intended to set a rire underneath people, to get them up and moving in the interests of specific cause. That is the tradition out of which Das Wort was conceived.

The Bolsheviks, as in so many things, provided the German Communists models for such literature. In Russia, the tradition of such committed journalism predates the Bolsheviks. Commenting on the requirements faced by a would-be editor of a journal, one Russian emigre remarked:

The point was that all the Russian journals had been linked with a definite world outlook. A world outlook lay at the basis of every political line and every journal. Such was the Russian tradition. The Russian intellectual was not capable of living or acting without a world view. There was nothing one could do about it. .... 2

A strong philosophical tendency was not merely de rigueur for a Russian journal, it was actually a requirement for success. It was as if Russia had never quite picked up the idea about civilized debate and giving all sides a chance, the norms of liberal "bourgeois" intellectuals of Western Europe.

In the Soviet Union, the hurley-burley early years of the Revolution were a period of ideological and doctrinal conflict. These disputes were not carried out within the pages of journals, however. The were promulgated among journals, each of which was considered a weapon in the hands of the movement or faction which published it, a weapon used to attack and destroy opposing viewpoints. Many were literary journals in the sense that they provided criticism of contempory literature and expounded on literary theory. But they were also political: they pushed a specific literary-aesthetic line 
which was closely aligned, and orten indistinguishable from, a political doctrine. For example, the proper attitude to be taken to the fellow-traveling writers was at once a matter of literature and of politics. In a state whose government claimed the authority and the right to direct every aspect of peoples' lives, culture required a policy, and cannot be differentiated from politics.

In Germany, there were also many literary-polemical journals, both Left and Right. Fritz Schlawe, in his survey of literary journals between 1910 and 1933, lists 12 different publications in his sections entitled "Literarisch-politische Bläter" ( 72 ). With the collapse of the Hohenzollern dysnasty, and the success of the revolution in Russia, extant radical left-wing journals now became associated with particular revolutionary factions, and new journals were established to promote a factional viewpoint. The Cerman version of the Russian Proletkult was trumpeted in the pages of Franz Pfemfert's Die Aktion (2ammito 24ff, 66, and Schlawe 86 ). Positive images of Bolshevik Russia and its policies were provided by Stefan Croßmann's Das Tage-Buch, founded in 1920 (Zammito 61). In point of fact, both Die Aktion and Das Tage-Buch carried numerous enthusiastic - and uncritical - articles about the Soviet Union (Zammito 62 ). Das Tage-Buch was more independent than Die AKtion, however, and occasionally did publish articles and exposes critical of the Soviet Union (Caute 52). 
Carl von Dssietzky's Die Weltbühne was another liberal journal. This weekly journal had a long (1905-1933) and very distinguished history of being in the avantgande of political and cultural matters. Kurt Tucholsky made his reputation as a effective gadfly in its pages. Yon Ossietzky and Tucholsky directed most of their attacks against the right, rather than the Social Democrats, the favorite targets of Communist journals such as the KPD's newspaper Die Rote Fahne (Rühle 165).

Die Weltbühne also had a reputation for critical objectivity in its portrayals of the Soviet Union. As late as the Fall of 1930 it "published a formidable protest of intellectuals, headed by Einstein, Heinrich Mann and Arnold Zweig, against the trial of forty-eight specialists then under way in Russia."4 As the political crisis became extreme in the late Twenties, however, it became more difficult for such a journal to maintain intellectual balance in its view of the Soviet Union. Communist writers such as Egon Erwin Kisch became more prominent in its pages as the intellectual Left closed ranks with the Communists. Accounts of the Soviet Union became more enthusiastic and very rarely even slightly critical. Even before exile the idea was alive that supporting and extolling the Soviet Union was concommitant to opposition to the Nazis. In this view, support of the USSR was a logical and consequential attitude for those genuinely opposed to the Nazis. The corollary to this formulation, that any criticism of the Soviet Union marked the critic as a supporter of the Maz1s, was to be a drag on any possibility of success for the United Front, and to doom it to a lingering death as the Great Purges 
unfolded in the mid-Thirties.

Despite the growing polarization of German political life which was driving independent leftist journals to take a more pro-Soviet attitude, the KPD writer-politicians could not abide independence of any sort, even it were only organizational cor more to the point, perhaps, especially if it were organizational). The Bund protetarisch-revolutionärer schriftsteller, founded in 1928 as an organization "exclusively for Communist intellectuals" (Zammito 107 ). Johannes R. Becher considered the foundation of the BPRS the official beginning of the literature of the DDR ( $Z$ ur Tradition 1). The organization found it necessary to publish its own journal, Die Linkskurve. Zammito explains:

Initially the BPRS sought to work with existing left-radical journals, but the question of ideological purity versus intellectual and artistic quality ruined its association with Die Front and then Die Neue Bücherschau. (2ammito 108)

Zammito then quotes Kisch, whose remarks might stand as the epitomy of the application of Parteilichkeit to artistic matters: ". . in our view the literary purveyor of political propaganda material towers above all superior world poets, above all Benns or Stefan Georges" (Zammito 109).

With exile, the left-wing or communist journals in Germany either ceased publication or set up shop out of the country, of ten with names which clearly sought to retain continuity with pre-Nazi publications.5 Die Weltbühne became Die Neue Weltbühne, Das Tage-Buch, Das Neue Tage-Buch. These two journals led a fascinating and relatively long-lived existence in the years of the exile. 
Das Meue Tage-Buch, under the editorship of Leopold Schwarzschild, began its existence as a distinctly radical-lertist journal which placed high value on remaining non-aligned in leftist party politics. ${ }^{6}$ At rirst maintaining only a mildly critical attitude toward the USSR, and on the whole remaining positive toward the goals and possibilties in that country, the Purges caused Schwarzschild to become more critical. The Communists, of course never too happy with Marxists who refused to come under Moscow's tutelage, recognized in Schwarzschild a Trotzkyite and attacked him virulently. Not one to be cowed, he refused to knuckle under. Until the Russo-German Non-Agression Pact, however, he still spent most of his vitriol on the Mazis. Following the Pact, the Comintern apparat exercised tremendous pressure in Europe to get the Communists there to pay lip service to the new line, or at least shut up about it, but Schwarzschild resisted and launched a savage campaign of anti-Soviet venom in the page of his journal.

Schwarzschild turned the Comintern line inside-out: he now considered support of the Soviet Union equivalent to helping the Mazis. From being an efrective contributer to the anti-Nazi campaign, Schwarzschild became an embittered and monomaniacal anti-Soviet propagandist, useless for the greater struggle. Such was the result of the strident demands for Soviet boosterism which the Comintern literary functionaries made on their comrades overseas.

What happened with Die Neue Weltbühne is a similar story with a different ending ( $c f$ Walter 24-71). Carl von Ossietzky, editor of DNW's progenitor, did not escape from Germany, as we have seen. 
Editor of the new journal in exile was Willy Schlamm, a former KPD member who was, in ract, a Trotzkyite. Trotzky himself published in Schlamm's journal during his one-year editorship. Schlamm set about to discover the real causes for the victory of the Nazis and, unlike the Communists themselves, did not paper over the role played by the KPD's unmitigated sectarianism during the Weimar Republic. He rurther analysed the actual situation in Germany, concluding that the Mazis were not tottering on the brink of disaster, that Hitler's popularity was growing, and that there was no rising red tide of oppressed workers ready to sweep away the Nazis. These notions, ravored by the Party leadership, were simply wrong, at best wishful thinking and a counterweight to defeatism and dispair; at worst total conceptual misaprehension and refusal to face facts, driven by the dogmatic ideology of an entrenched corps of professional revolutionary bureaucrats, "parteiorfiziös" in Schlamm's nasty terminology (Walter 30). The Comintern and IVRS of fice in Moscow did not view Schlamm's "deviationism" very kindly. In a manner too complex to relate here, Schlamm was soon replaced (Walter 37).

His successor, Hermann Budzislawski, soon brought NWB into the Party rold. The journal settled into the pattern set by the IVRS for Internationale Literatur. At first continuing the attacks on the Social Democrats for their guilt in the German debacle, then letting up on them and opening up to non-Marxist symapthizers. Non-alignment and non-intervention, appeasement, German rearmanment and Soviet construction ( $A$ L $f b a u$ ) were the concerns of this journal in the mid-Thirties. It followed the party line 
concerning the Moscow show trials. Ironically, and rather pathetically, in an article published exactly one week after the Russo-German Non-Agression Pact was signed, August 22, 1939, Budzislawski attacked the Soviets' new policy:

Sollte es für die Haltung der Sow jetunion Gründe oder gar Rechtfertigungen geben, so könnte ich sie nur auf dem Gebiete der russischen Staatsraison sehen, und somit trären diese Gründe für Menschen, die nicht Sow jetbürger sind, keinesfalls zu. (Walter 70 )

That was the last issue of the journal. Before the next week was out, the war began and the French authorities closed it down.

Thomas Mann's journal Mab und Wert attempted to rind a secure but not isolated island on which culture might weather the storm, without sacrificing the integrity or political engagement which Mann came to agree was required of art in a world of Hitlers and Stalins. But the honor of getting the first emigre zeitschrift going went to Mann's son Klaus. He set up Die Sammlung, which attempted to continue the tradition of apolitical, specifically literary journals, but with a leftist viewpoint. Maintaining any sort of balance in these times proved to be a daunting task (Walter 424 ). Klaus Mann took the artistic high ground, as did his rather: "Diese Zeitschrift wird der Literatur dienen: jener hohen Angelegenheit, die nicht nur ein Yolk betrifft, sondern alle Yölker der Erde (Walter 425). He goes on to say that "Eine literarische Zeitschrift ist keine politische, . . ." Nevertheless, "Trotzdem wird sie heute eine politische Sendung haben... Von Anfang an wird es klar sein, wo wir hassen und wo wir hoffen lieben zu dürfen" (Walter 425). Klaus Mann's effort here seems to be to stake out a kind of partyless, but 
at the same time, political and literary Popular Front, an alternative to the Comintern-directed movement whose literary journal Das Wort came to be. His attempt to squeeze into a niche among isolated defeatists, again'-'em-all Trotzkyites, and Comintern dirigistes, politcally engaged but without party affiliation or factional narrow-mindedness, had the expected result. Die Sammlung went under in August 1935 for financial reasons.

other journals were essentially brand-new undertakings, even though their names suggested an association with pre-exile publications. Neue Deutsche Blätter was one such. Oskar Maria Graf, whose name was to appear so often in Das Wort, played a large role in its appearance in September 1933 (Walter 447). NDB had the Popular Front idea already in hand when its editors (Graf and Wieland Herzefelde declared: ". - Die 'Neuen Deutschen Blätter' wollen ihre Mitarbeiter zu gemeinsamen Handlungen zusammenfassen," and "Sie [ the Blätter] wollen mit den Mitteln des dichterischen und kritischen Wortes den Faschismus bekämpren" (Walter 449). They Eo on to concede that the "Zusammengehörigkeit der antifaschistischen Schriftsteller ist noch problematisch," yet the fight against the Mazis demands toleration of others: "Wir werden alle - auch wenn ihre sonstigen öberzeugungen nicht die unsere sind - zu Wort kommen lassen, wenn sie nur gewillt sind, mit uns zu kämpren (Walter 449). A more compact statement of the Popular Front concept would be hard to formulate. The editors of $N D B$ were dedicated Marxists, yet they were open to cooperation with angone in the struggle against the Nazis (Walter 450). $Y D B$ remained committed to 
the proto-Popular Front line throughout it short history (1933-1935). NDB lacked one important trait to become the Popular Front literary journal, however: it was not parteilich, which meant in practice that it was published in Europe beyond easy Comintern direction. It was Marxist, it espoused all the right ideas, including support of the USSR - but it was not communist. In other words, it was not administratively under the thumb of the Comintern. That would only come with the establishment of a journal in Moscow, despite all the difficulties that location would create in distributing the issues in Europe and maintaining contact with editors and contributors. Lacking the Comintern's financial support, and located in Prag, where the government was coming under increasing Nazi pressure to do something about those pesky exiles, $N D B$ rolded in August 1935, ironically exactly the month and year when the United Front was at last "officially" proclaimed with great fanfare by the Comintern at its Seventh World Congress in Moscow (Pike, Writers 79 ).

There was in fact already in existence in Moscow a journal which, while not an émigre publication as such, certainly was under the Control of the Comintern. What is more, it had already proclaimed in its own pages the necessity of a literary United Front. This was Internationale Literatur, published in German as well as several other languages by the Internationale Veneinigung nevolutionäner Schriftsteller. The IURS was a sort of literary Comintern, whose paternity in various organizational guises dated back to the mid-Twenties. ${ }^{7} I L$ first appeared in June of 1931 . For 
the first year of its existence it was called Literatur der Weltrevolution; until 1935, the line "Zentralorgan der IVRS" appeared underneath the title-heading (Walter 377). The importance attached to $I Z$ is demonstrated by the ract that the biggest star in the German Communist constellation or writers, Johannes R. Becher, became chief editor in 1933, undertaking sole editorial responsibility in 1938. The journal survived until July 1943. That is certainly remarkable considering the extreme shortages of material resources in the Soviet Union during the war. Its function was to provide the Communist writers of the world a rorum for their work and a medium for the proclamation of doctrine and for centralized direction. The primary themes were the USSR, the worldwide class-struggle, and Internationalism, by which was meant that the publication, no matter which language it was in, was to be viewed as a super-national organ, above the parochial interests of a particular national group of Communist writers (Walter 379 ). Promoting a positive image of the Soviet Union and its policies was very important, indeed, primary function of this journal. Much space was devoted to Soviet literature and to publishing of ficial declarations of policy and doctrine, as well as plenty of material by German writers about the Soviet Union (Walter 300rs.).

It was probably this aspect of $I L$ more than any other which made it inappropriate to try to adapt it to the propaganda needs of the United Front, which was after all only a tempory policy contrivance meant to deal with the tactical - if quite dangerous problem of Fascism. $I L$ was for dedicated and parteilich 
revolutionaries. For them the USSR was the fount of inspiration and direction for the world struggle. Not intended to be read by non-Communists or fellow-travelers, it was the house organ of the International Communist movement in literature. In ract, as early as the beginning of 1933 , it had proclaimed the need for the creation of an "Einheitsfront von Schriftstellern gegen Krieg und Faschismus" (Walter 450). These assertions notwithstanding, $I Z$ could not bring itself to besmirch its pages with the work of non-Marxist writers (Walter 450).

The Communists themselves were well aware that $I L$ was far too closely associated with the Comintern, and with Moscow, to be an effective organ for United Front. Already in the late Summer of 1933 Johannes R. Becher had been assigned by the IVRS to reconnoiter things among the exiled literati in Europe. In Prag he became aware of the plans of Klaus Mann to establish a new anti-Fascist journal. Becher would later report, commenting on the the need for a new anti-Fascist publication: ". . . in der Angelegenheit der Zeitschrift, als eines wichtigsten [sic] Organisationsmoments der antifaschistischen Kräfe in der Literatur ..." (Walter 447). By which Comintern bureau-speak he seems to have been saying that a journal was indeed a necessity at this time, and that the fight against the Fascists was going to have to be organized. Furthermore, the IURS, (or the Germans' BPRS) were the right organizations to be undertaking this job.

But Becher was out in front of his IURS comrades in this matter. The United Front did not become policy until 1935. By then, 
several journals in Europe which might have served as an organ for the United Front had come and gone. And in Moscow, the natural venue for such an enterprise (in the control-minded view of the IVRS literature bureaucrats), their own publication, $I L$, was deemed unsuitable for such a task. Clearly, by late 1935 there was need for a journal devoted entirely to promoting the Popular Front, one open to non-Communist writers, one whose only proviso would be a common opposition to the Nazis, journal whose fiscal (and for that matter, physical security ) requirements could be ensured. That could happen only in Moscow, under the benevolent supervision of the IURS and the Comintern.

\section{PERSONALITIES AND THEMES}

The first issue of Das Wort appeared in July, 1936. The names of Bertolt Brecht, Lion Feuchtwanger, and Willi Bredel are given as the editorial board (Redaktion) of the new journal. Fritz Erpenbeck, who took over editorial responsibilities after Bredel's departure from Moscow, refers to them as the "Herausgeber" in the "Nachwort" to the facsimile edition published in the GDR in 1968 (Registerband 5 ). Brecht and Feuchtwanger had very little to do with bringing the project to fruition, Bredel much more. Early on he knew that he would be co-editor and probably have most of the responsibilty for actual editorial work, especially since he was the only one of the three "Herausgeber" to live in Moscow, where the journal was printed.

He and other writers and cultural prominenti had taken part 
in a Congress in Paris in the Summer of 1935 organized by Willi Münzenberg, the "International Writers' Congress for the Defense of Culure" (Rühle 421). Informal discussions between him and Mikhail Koltsov, a well-known Soviet jounalist and literature bureaucrat of the day, had broached the possibility of Soviet financial backing for a new literary journal for the Popular Front (Pike, Exilproblematik 3, Walter 461). He was an editor of Pravda and ran the Jourgaz publishing enterprise in Moscow, and thus could speak for the Soviets from a position of of ficial authority. Concerning the financial backing, the great Achilles heel of emign journals, Walter makes the reasonable case in reference to Das Wort, that "Man darf deshalb unterstellen, daß die Zeitschrift von den Subventionen des Jourgaz-Verlags gelebt hat, später von denen des Verlags Meshdunarodna ja Kniga (Moskau), an den sie ab Juli 1938 überging" (Walter 462).

Keen Soviet interest in this journal was clear from the beginning. Anyone who has spent time in the Soviet Union and understands the frustration faced by Westerners in getting things done there on time, will agree from the following illustration that Michael Koltsov and his superiors did indeed consider Das Wort an important undertaking. Erpenbeck writes laconically of publishing in Moscow:

Keines der sogenannten Journale, worunter man alle "dicken" künstlerischen und wissenschaftlichen Zeitschriften verstand, kam damals in der Sow jetunion pünklich heraus, ganz davon zu schweigen, daß "Herauskommen" noch nicht identisch ist mit dem Erscheinen auf dem Markt. (Registerband 14) 
Nevertheless, "Das Wort' war, so unglaublich das heute klingt, in Moskau das einzige 'Journal', das keine Unzeitschrift war" (14).

To Bredel, Maria Osten and the other Communist literary functionaries, the Popular Front was in great need of its own, specifically literary journal. Neue Deutsche Blätter had finally expired in August of $1935 .^{\circ} I L$ was too closely tied to the Comintern and the Russians:

Wahrend die IL auch in den Jahren der volksfront fast auschliesslich den Standpunkt von Komintern und KPD literarisch-politisch vertrat, war das Wort darauf orientiert, jene Einheit von Antifaschisten verschiedenster politischer Richtungen literarisch zu dokumentieren, die im politischen Sektor die Volksfront $z u$ erreichen trachtete. (Walter 468)

Congresses such as that mentioned above demonstrated that there was great support among the prominent literary names in Europe for concerted action against the Nazis. What was needed were famous writers of international fame who were not associated directly with the communists - and the Soviets. This is the key to understanding the Popular Front policy, Das Wort's reason for existence. It is also the reason for the ultimate failure both of the journal and of the policy. The Soviets were well aware that being too closely tied to them reduced the effectiveness of agitation for those very policies which would benefit them: Western rearmament, intervention in Spain, public outcries in the West gainst internal German actions - in short, anything to increase tension between Germany and the Western Democracies. The Popular Front was the public, non-governmental version of the Soviet diplomatic campang to build a cordon sanitaire around the Germans, the policy by which Stalin hoped to compel Hitler to keep himself occupied in the West, 
not the East. Soviet citizens and Communist Party members would not get a hearing in the West. The stars among the intellectuals and writers would. Their appearance alone in the pages of Das Wort, notwithstanding what they happened to be writing, would lend legitimacy to the causes which were espoused in its pages. There would be plenty of opportunity for reliable, if lesser known, writers to disburse the correct views on the topics of the day.

So, if the new journal were indeed to contribute to the Popular Front campaign, important names were needed. Soviet interest in one such name, that of Heinrich Mann, is a topic in David Pike's interview with Marta Feuchtwanger. She says:

Und dann haben sie [the Russians] sich an meinen Mann und dann Heinrich Mann gewandt. Beide wohnten damals in Südfrankreich. Und dann hat Heinrich Mann meinem Mann Besagt, ich kann nicht nach Rußland fahren, das ist mir zu anstrengend - er war schon zu alt und war nicht gesund genug - aber wenn Sie fahren würden, das wär sehr schön; denn die Rußen haben nämlich gesagt, sie gäben uns das Geld, wenn sie einen richtigen Namen hätten... jemand, der schon Namen hatte. (Pike, ExjJprobjematjk 4)

Frau Feuchtwanger's assertions of Russian offers of money notwithstanding, it was apparently a problem over salary which in the end caused Mann to decline the proferred editorship (Pike, Writers 207). It was certainly not because of any differences over politics: Mann was something of a leader in the Popular Front movement and bore nothing but good will for the Soviet Union (Pike Exilproblematik 4 ).

Lion Feuchtwanger did accept the responsibility. He was a very fine catch for the Soviets: his historical novels were extremely popular the world over, and his name was well known to them. 
Millions or his novels had sold in the Soviet Union. He was equally important because he was the only "Herausgeber" of three whose credentials were "bürgerlich." Wredel was party, and Brecht very close to being so, although not a member.

Feuchtwanger's participation in the editing duties had to be carried out by mail with Bredel, as did Brecht's. More important to the Literaturverwalter in Moscow than editorial participation as such were Feuchtwanger's contributions of material: excerpts rrom novels, polemical attacks, critiques and commentaries. Although he was a very pro-Soviet fellow-traveler, he remained technically neutral and spent the exile years in France and the United States. His Popular Front legitimacy was not comprimised by residence in Moscow. He was exactly what the Soviets were looking for.

Brecht's case was somewhat different. True, his dramas were very well known, he had a big name, and he was not a party-member, all desired characteristics for the Popular Front. He was a very prolific writer who refused to engage in artistic disputes with other writers, preferring to concentate on production rather than polemics. He was a problem for the Literaturpolitiker of this time as he was to be for those of the GDR following the war. His politics sounded right, he espoused the revolution of the proletariat, the end of capitalism and corrupt bourgeois democracy, the whole program. But he refused to toe the line in artistic matters, maintaining that individual creative liberty was the sine gua non or making good art. He rollowed his own muse and produced plays which conformed to his own theories of art, rather than those promulgated 
by the turgid theoreticians of Socialist Realism, which had been Elven official sanction by the first Congress of the Union of Soviet Writers in 1934. The great popularity of his works, his prolific output, and his keen sense of profitable business and the financial independence which that provided him, all made him a power in his own right. His popularity was just too valuable an asset for the Communists, they could not let him go over ideological matters incomprehensible to most theater-goers and readers. Frankly, he was too good an artist. His contributions to Das Wort, and his name on the masthead, gave the journal a cachet worth far more than aestretic orthodoxy.

Willi Bredel's personality was apparently well suited to dealing with the problems which were bound to arise with such an arrangement, and with such strong characters. ${ }^{\theta}$ At first especially, Brecht and Feuchtwanger made every effort to participate actively in the editorial functions. Hugo Huppert writes concerning their participation that Das Wort was "von ferne ausdrücklich und tätig mitredigiert" by them (Walter 465). Hevertheless, the onus of responsibility and work was on Bredel.

Bredel's career with Das wort did not last long. By early 1937 his attention had turned elsewhere, and he was soon off to Europe and Spain, leaving Das Wort to Fritz Erpenbeck, who became the de facto sole editor. Brecht and Feuchtwanger were heavily involved in their own work, and pretty much had to accept that fact that they oould have little effect on what was happening in Moscow from their exile retreats in Denmark and France. Erpenbeck's services were 
lent to Das Wort by Johannes $R$. Becher, the editor-in-chief of Internationale Literatur. Erpenbeck had been connected with the new journal since its inception: he had discussed with Koltsov at the 1935 Paris writers conference the need for a new journal. He was a trooper. In addition to most of the actual editorial work, he carried out the grinding work of getting the journal compiled, printed, and sent off to its distant subscribers. This work was rendered more difficult as the practical problems of the timely receipt of manuscripts became acute as Hitler gobbled up more and more of central Europe (Walter 465). With Bredel's interests moving elsewhere, Erpenbeck took over editorial duties entirely in the Spring of 1937. After Bredel's departure, Das Wort became for all practical purposes the sole product of his editorial selection.

Despite the fact that by 1937 none of the nominal editors of the journal were in Moscow, their valuable names all remained on the masthead until the end, which came after the March 1939 issue. Erpenbeck's name was given no special prominence, although he did have the privilege of writing several of the Vorworte which appeared in many issues. He had to content himself with the knowledge of a job well done. Writing of his time with Das Wort, Erpenbeck emphasized the role of Das Wort in the Popular Front: “. . in ihrer Grundkonzeption und Haltung demokratischantifaschistisch. Sie ist ein Kind der Volksfront" (7). Das Wort was to be the journal of the German Popular Front, a forum for writers of all political persuasions. 
Erpenbeck comments on Das Wort's role:

\begin{abstract}
"Das Wort" sammelte also um sich einen Kreis antifaschistisch-demokratisch gesinnter futoren vom Kommunisten bis zum Christen, vom parteilosen bis zum deutschnationalen Hitlergegner, und es fehlte weder der Anarchist und Pazirist noch der bürgerliche Demokrat und Liberale. ( 7 )
\end{abstract}

This is the idea of a Popular Front in literature in its purest form. It will be seen that, while the political leanings of the contributers may indeed have been as varied as Erpenbeck claims, the product which Erpenbeck turned out was much more limited in scope. Ultimately, it's effectiveness in the anti-Mazi campaign was to be compromised irretrivably by its increasingly strident support for Soviet Russian policies.

The Soviets did not scimp when it came to financing their German magazine. It was never intended that it should be a paying proposition. They knew that it would cost money to promote the Popular Front idea among German fellow-travelers in Europe, and were willing to pay to advance their policy. Writers were paid fees high for the day, and in hard currency. Erpenbeck refers to the ". . relativ hohen, in Yaluta transferierten Honorare." A fee for a "Mittelgroße Arbeit" was large enough that it ". . dem Empräger oft für Tage oder manchmal Wochen Nahrung oder Miete sicherte" (Nachwort 8). Subscription rates were very reasonable: three dollars 2. year for the U.S.A., 12 shillings in England (Das Wort Moskau 28 ). Figures on the size of the printings are hard to come by, but Manfred Engelke, relying on Soviet sources, estimated runs of between 10,000 and 12,000 , a huge (and expensive) investment of paper and press-time in Moscow (Walter 462). Individual copies of 
the journal encompassed 112 pages through December 1937, then were increased to 160 pages (Das Wort Moskar 25-26). The largest issue numbered 176 pages. That entire issue was devoted to the Twentieth Anniversary of the Great October Revolution in Russia.

Feuchtwanger declared that he wanted a journal for which he would have editorial responsibility to be ". . ein literarisches organ von Format" (Walter 463). He goes on to call for ". - produktive Literatur in würdiger Form." (Walter 462). Much thought to format and layout is evident in Das Wort, as well as much plain hard and painstaking work. Typographical errors are few, the printing is clean and sharp, there are quite good illustrations and reproductions of drawings and paintings, and there is little overt evidence of "cutting and pasting." It is a quality product, a worthy showcase for the Popular Front in literature.

In that same letter, Feuchtwanger lists the kinds of literature he wished to appear:

- . Für den deutschen Roman, die deutsche Lyrik, die deutsche Novelle gibt es heute kein Organ, sondern, darüber hinaus haben die Zeitungen und Zeitschriften der Emigration keine Möglichkeit, Analysen der neu erscheinenden Belletristik $z u$ bringen, die den Namen Kritik verdient. Es erschiene mir deshalb sehr vielversprechend, wenn die neu zu Eründende Zeitschrift sich darauf beschränkt, Literatur zu bringen und literarische Kritik ... (Walter 463)

Real literature it was to be, belles lettres and criticism - or that is what Feuchtwanger expected. The traditonal genres were certainly there. But derining just what constitutes literature is not such a straightrorward thing - and editors such as Bredel and Erpenbeck, for whom the political slant of a piece of written material was the primary criterion of its value, were not going to quibble 
about matters of form when selecting items to print. The "child of the Popular Front" was to be a journal in which the word would be free - and the genre as well. In the "Vorwort" of Heft $\operatorname{Mr} 6(1936)$, Willi Bredel writes:

Wir glauben wahrgemacht zu haben, was wir im ersten Heft als Grundsatz unserer Zeitschrift ansprachen, das nicht uns ferner liegt, als Einförmigkeit und ofriziösentum. Wir wissen, daß unsere Leser gerade die Vielrältigkeit der Beiträge unserer Mitarbeiter, sei es aur dem Gebiete der Dichtung, der Kritik oder des Essays begrüßen,... (June 1936: 5)

These remarks may well contain an ever so subtile hint of disgruntlement with developments in "official" communist literature, where Socialist Realism and a very limited expressive palette had become the sanctioned norm. Perhaps not, but the editors were at pains to express their determination not to limit content or form in a journal whose only reason for being was to appeal to a very diverse group of readers and writers.

The communist writers in the Weimar Republik had developed their own agitational reporting style whose devotion to factual accuracy was less important then its potential to outrage into action, or convince the reader by example of the effectiveness of this or that Communist policy. Called Reportage, it was a kind of investigative reporting comme travelogue, except that the writers did not expect to be called to task for their racts. John Reed's Ten Days that shook the World would be an example of the genre. 10 We will see plenty of this sort of thing used to paint a positive picture of the Soviet Union. The American reader might expect to see such items confined to the Sunday papers, but they were considered more than suitable to be included in Das Wort. 
Lion Feuchtwanger also failed to add to his list drama. Das Wort featured excerpts from plays, miniature Theaterstücke, and, in one notable case, an entire three-act short play by Friedrich Wolr. Called Tanjka macht die fugen auf, this fascinating piece of

soap-operatic propaganda appeared in the large October Revolution issue (Mov. 1937: 59-107). Many or Bertolt Brecht's contributions to Das Wort were excerpts from plays in progress. Two scenes from his Funcht und Elend des dritten Reichs were reatured in the last 15sue of the journal (Mar. 1939: 3-10). Der spitzel is a seven-page playlet which also appeared in the journal (Mar. 1938: 3-10).

The editors placed great stress on the task of "capturing" the Cerman cultural and literary heritage for Germany in exile. And not for Germany alone: for world culture as well. Most issues of the magazine featured a Kulturerbe section highlighting by comment and example the works of various writers of the past who were seen to be in a tradition definitely not alive in Germany under the Mazis. Non-German writers were also included in this category. The Russian literary tradition, and treatment it was getting by the new Soviet state, was given a large role to play in promoting the image of the Soviet Union. As with the matter of form, whether a writer was cor had been) of bourgeois or noble heritage, it no longer mattered in the great struggle underway in the world. Such concerns were never far below the surface for the communist writers and ideologues, but word had come down to rorget the niceties and get out there and work with those erstwhile class enemies of the bourgeois and liberal camps. The overall theme of everything which was printed in Das Wort 
was supposed to be the commmon struggle against Fascism by the rree people of the world. This fight was seen as an international one, which should be waged by everybody against Fascist regimes everywhere: not only Germany, but in Italy, Spain, China and Japan. Opposition to one fascist regime was oppostion to them all. Articles and stories and poems were featured which depicted the struggles in these countries and apotheosized their heros.

Such an internationalist approach was all very well, but Das Wort was a German magazine for German readers. And since Germany was certainly the primary enemy of Europeans, and especially of the Soviets who were financing Das Wort, Germany was the primary topic. Mazism meant war. That was the primary message. As such, it was not too hard to demonstrate Hitler's warlike intentions, since he was wont himself to trumpet them around and brag about Germany's growing military might. The ideology and policies of the Nazis went hand-in-hand with its militarism, of course. Mationalism, Mazi race theory, crazy cultural policy, the antics of the Nazi leaders, these could be satirized or lampooned in poems and stories. Particularly in "An den Rand Eeschrieben" articles from the German press and statements by their leaders were discussed and jeered.

But the German writers in exile had a problem: they were in exile. Their sources of information from within the Reich had dried up rather quickly, and now were mostly from the German press itself. And the communist writers in particular had another problem: they refused to race racts about what had happened in Germany. They kept predicting the imminent downfall of the Mazis even as Hitler's power 
Erew. Despite the Popular Front, they would never admit that the Communists may have made grievous errors during the Weimar Republic. Besides, the battle was over in Germany, the war had moved elsewhere, as had the exiles themselves.

The Spanish Civil war rates special mention in this context. Begun at about the same time as Das Wort began publication, it was seen by the Popular Front politicians as the last chance to stand up to Fascism in Europe. If Spain went Fascist, France would be next and England would inevitably sall, leaving the Soviet Union alone against the Fascists. Hitler and Mussolini had come in on Franco's side to prevent a communist toehold being established in Western Europe. And it was also good training for a rebuilding German army and, especially, air force. Stalin's prestige was threatened, and perhaps he also saw an opportunity to enveigle England and France into a conflict which could possibly get them involved directly against the Germans. As long as the war there lasted, this chance existed. To prop up the wavering Republicans, Stalin intervened in a fairly major fashion, preventing the rall of Madrid in the Fall of 1936 (Kennan, Russia 309). By early in 1937, however, it was clear that Franco's Falangists were going to win eventually. Stalin provided enough support to keep them going two more agonizing years, but his "volunteers" spent most of their efforts rooting out Trotzkyites and "deviationists."11 Nevertheless, the Russians had done something, which is more than could be said of the governments of France, England, or the United States.

The stories and poems and Reportages which deal with the 
Spanish Civil War are among the best work to appear in Das Wort. They are filled with real enthusiasm and a Eenuine goodwill for the Spanish people in their great and tragic calamity. Willi Bredel, who fought in the Thälmann Brigade, and $M$. Koltsov, both provided coverage from the fronts. Beginning with the November 1936 issue, something from Spain appeared in nearly every issue. Articles about Spanish artists, writers, philosophers - the Kulturerbe of Spain proliferate. The approach is similar, if not as intense, as that which was utilized to pant such a positive picture of the Soviet Union.

Inevitably, the Soviet Union was a major topic in many issues of Des Wort. The Communist writers, who had tied their all their efforts and hopes for a better Germany to the model of a new world which was being built now in the Soviet Union, turned to that country to find examples of all the positive values they were righting for. By doing so, they violated the original raison d'être for the journal. Das Wort had been created specifically to promote a literary Popular Front in a journal not too closely linked to the Soviet Union. Yet the pressures on its Communist editors and Soviet backers to provide a positive image of that country were too severe to resist. The Soviet Union and all it claimed to stand for was the country which was most threatened by the Nazis. It was the country whose social system presented the greatest contrast and challenge to the Mazis. It was the country which was in the forefront of the movement to thwart the Hazi plans. And in the end it was a country ideally suited to provide literary ammunition for the campaign of invidious comparison which was at the heart of the work of Das wort. 
HOTES TO CHAPTER III

1 Walter 480-489 is a good condensed exposition of the "Expressionism Debate."

2 I.O.Fondminskil \& Bunakov, as reported by M. Yishnyak. Cited in Robert A. Maguire, Red Virgin Soll: Soviet Literature in the $1920^{\prime} \mathrm{s} 43$.

3 Caute 52 and Schlawe 79 . Yon Ossletzky died in a Nazi concentration camp. He was winner of the Nobel Peace Prize in 1936.

4 Caute 52. My account of the predicament of Die Weltbühne draws heavily on Caute. Portland State University has a complete set of this journal for those interested in further research into this fascinating journal.

5 The most thorough and encompassing treatment of the exile journals is found in Hans-Rlbert Walter Deutsche Exilliteratur 1933-1950. Yo. 4. A briefer but nonetheless quite useful coverage of the major journals is round in Matthias Wegener Exil und Literatur: Deutsche Schriftsteller im Ausland 1333-1945.

6 Walter 73-127 is the primary source of my abbreulated coverage of what happened to this journal. The interpretation is $m y$ own.

7 See Pike 278 . and elsewhere in his book for the nitty-gritty details about the evolution of this organization.

8 David Pike's account of the demise of $N D B$ provides a fascinating look behind the scenes at the IURS Kulturpolitiker at work as they traveled around Europe drumming up support for the Popular Front (Writers 199rs.).

8 Walter 466 quotes Hugo Huppert's complimentary comments about Bredel's qualities which made him just the right kind of editor for the Popular Front journal.

10 Egon Erwin Kisch specialized in this form, with rather less success than Reed. See his "Reportage als Kunstrorm und Kamprform" in Zur Tradition 1: 877-880. He names Reed and Mikhail Koltsov, among others, as examples. See also Sivia Schlenstedt's Wer schreibt, sandelt.

11 George F. Kennan attributes Stalin's behavior to his fear of the "great liberal enthusiasm which attached itself, as an international phenomenon, to the Republican cause." Most of the Russians involved in the conflict were later purged, including the peripetetic Mikhail Koltsov (Kennan, Russia 310) 


\section{CHAPTER IY}

\section{THE NEW MAN IN THE NEW STATE}

The first issue of Das Wort contains not a single major article about the USSR. Yet this apparent resolve to keep the Popular Front in literature detached from suspicions of Soviet national-interest motives, the bane of the policy, did not last long. Articles soon appeared in which Russia and the Soviet Union provided all those positive images which, in the minds of the editors, would condemn Nazi Germany by comparison. The strength and vitality and enthusiasm displayed in Das Wort's portrayals of the Soviet Union would give hope to oppressed people and those who had been driven from their own countries. And the Soviet Union itself would be strengthened by the good-will and support engendered by these images.

The country which readers saw portrayed in Das Wort had undergone massive and radical changes since old Russia had been abolished in October 1917. The depiction of that transformation and the resulting new society was a major means by which the Communist editors of Das wort tried to convince the reader that the Soviet Union was a nation worthy of support and a fit partner in the common struggle. The nature of the current government and societ $y$ in Germany was always the background for these portrayals, aganst which they were contrasted, even if Germany were not specifically 
mentioned. What was it about the Soviet Union which attracted the attention of these writers so irresistably?

Oskar Maria Graf's "Ein Beispiel für Millionen Verzagten," an "Ansprache, gehalten auf einer deutschen Kundgebung in Prag," reveals much about the state of mind which made Communist writers reach to the Soviet Union in their efforts to find a good example to set against Mazi Germany ( Mar. 1937: 58-63). Grar's speech touches on many of the Soviet themes which Das Wort dealt with and is worth looking at in some detail.

Graf begins by pointing out that people from all walks of life want to express "ihre[r] aufrichtige[n] Sympathie für den bewunderswerten Sow jetstaat und seine glücklichen Volker" ( 58 ). This despite the ract that these people "zum größten Teil die politischen Auffassungen des Sow jetsregimes keineswegs teilen" (59). He goes on to compare this sympathy to the "schwärmen" which had been felt by Western sympathizers for Russia before the Revolution. This feeling had been due in large part to the "damaligen russischen Dichter und Denker," as well as "der dunkle, passive Geist dieser Sektierer und Mystiker," who "die Hirne und Herzen der westeuropäischen Intelligenzler beeinflußt hat" (59). The West had ignored the oppression and surfering and in justice which had been the reality of Czardom. "Wir wollten ja nicht einmal ein nüchternes, krasses Bild davon!" (59). We (the Western intellectuals) were not being kept in "Dummheit und Analphabetismus," nor were we being pursued by the Okhrana ( 59 ). We had created for ourselves the "Phantom der Sphynx "Rußland" (59). What we relt was not real 
"Sympathie," but "unkontrollierberer Hang" and an

"Hingezogenheit zum Fremden" (60). But real sympathie requires a "lebendige Anteilnahme." His introductory remarks conclude:

Das unterscheidet die damaligen Schwärmer für Rußland und did jetzigen Freunde der Sow jetunion voneinander. Jene verehrten - um es einmal philosphisch auszudrücken gewissermassen ein "Ding an sich", wir aber nehmen lebendigen Anteil an der stürmischen Entwicklung einer mächtig wirkenden Realität. (60)

Graf goes on to castigate the fascists for planning ". . ganze Yölker in Knechtschaft zu halten, die wesentlichen Bestandteile jeder Kultur zu vernichten und die ganze Welt abermals in einen Krieg zu hetzen" ( 60$)$. He asserts that with such danger in the world, this is not the time for "gegenstandslose[r] Schwärmerei," but to take a "eine klare Stellungnahme" (60). That is what the Soviet Union has done. Therefore, by supporting the Soviet Union you oppose the Nazis. Graf is making the connection here which is the ostensible motivation for the attention given to the Soviet Union in the pages of Das Wort. Graf elaborates his point:

Wenn wir also der Sow jetunion unsere Sympathie bezeugen, so geschieht das aus einem tief realen Grund. Denn diese Union der befreiten Yölker auf einem Sechstel der Erde ist ein übermächtiges Beispiel für Millionen verzagter Menschen, ein Beispiel dafür, daß die unsterblichen Ideen von Freiheit und sozialer Gerechtigkeit, von Fortschritt und Humanitat verwirklicht werden können! (60)

Because the ideals of the Western humanism are alive and thriving and being realized in the Soviet Union, that country stands as irrefutable proof that the ideas and policies of the Nazis are dead wrong. Thus the existence alone of the Soviet Union is a major contribuiton to the battle against the Nazis. Because the Nazis know this, the danger to the Soviet Union from them is the most acute. 
Therefore, the best way roreigners can help to oppose the Hazis is by helping the Soviet Union. This line of reasoning rests, of course, on convincing readers of such journals as Das Wort that the claims made for that country are true. That became the job of Das Wort.

Graf lauds Soviet nationalism, which brings together diverse peoples into "nation of a new type," to paraphrase Lenin. The Soviet Union is not the Russia of old. It is a:

". . Treie Völkergemeinschart . . obgleich erst jetzt das Nationale und Geistige innehalb ihrer Grenzen voll zur Geltung kommen können - auch nicht spezifisch "Rußisches im vergangenen Sinne mehr, sondern eine immer stärker fortzeugende Krart in der Aurwärtsentwicklung der ganzen zivilisierten Welt. $(60-61)$

Graf now launches into an oratorical paean to the new Soviet Union of differing nationalities. The October Revolution gave all these peoples at last the chance to realize their national aspirations. That is why ". - die Sow jetmenschen mit einer solchen Liebe für ihr großes, reiches Vaterland erfüllt sind" (61).

Grars asserts that ". . zwei gigantische Fünf jahrpläne Stalins dieses Land von Etappe zu Etappe zu höchster zivilisatorischer Vollendung gerührt haben" ( 62 ). Stalin began his plan for forced industrialisation and the construction of socialism in 1928 and by 1935 it was claimed that socialism had been created and that the country was well on its way to a modern technology and industry.1 Many articles in Das Wort serve to support these claims. The Russian man had been changed too: ". - Der träge, bedrückte russische Mensch hat sich verändert: er ist zum fanatischen Arbeiter, zum Stachanovarbeiter geworden;" He has also become "wißbegierig, unternehmend, tollkühn und heiter" (62). Collectivization, Stalin's 
brutal program which forced millions of peasants into collective farms and brought famine and death to millions - as well as destroying an agriculture which had been thriving and expanding under NEP - has resulted in: ". . . der vielfach gestiegene Reichtum des Landes" (62).2 The "Stalin Constitution," a favorite sub ject of fellow travelers in the West and of articles in Das Wort, is "... die mächtige, eindeutig sozialistisch-demokratische Verfassung" ( 62$\rangle$. Not quite social-democratic, but pretty close, clearly an appeal to the Communists' old rivals, the SPD.

Graf concludes his speech with a long discourse about "Vaterland" and "Vaterlandsliebe" and then attacks the Nazis directly:

2 weifellos verbinden die meisten freitheitlich gesinnten vorwiegend kosmopolitisch orientierten Menschen die bloße Bezeichnung "Vaterlandsliebe" mit dem überzüchteten, aggressiven Nationalismus raschistischer Diktaturen. Sie können es sich angesichts der 2 unahme dieses kriegerischen Nationalismus nicht mehr vorstellen, daß nur der jenige sein Vaterland wahrhart liebt, der ihm den Fortschritt sichern will, der innerhalb seiner Grenzen die soziale Gerechtigkeit fördert und der sich mit aller Kraft für die Erhaltung des Freidens einsetzt! Der Sow jetmensch - ganz gleich, ob er nun Russe, Ukrainer, Sibir jak, Tadshikistaner, Geogier oder sonst was ist - liebt in seinem großen Sow jetvaterland seine Heimat über alles, weil er sie wirklich besitzt. (63)

He really owns his country because the new social system has made that possible. It might easily be inferred by the reader of Graf's speech that the new society was also a model for the one which should replace Nazism after its ultimate defeat. The Popular Front policy precluded stressing publically such an idea, of course, but few readers can have failed to make the inference after such a glowing report on the new society. 
Graf's message, with which he concludes his speech, is that the peoples of the Soviet Union have achieved in their new society what they want, they have no wish to see their gains destroyed in a war: "Sie haben gelernt, daßs nur der Friede ihr Land und die ganze Welt vorwärtsbringen kann, nur durch ihn das gemeinsame menschliche Glück gescharfen werden kann" (63). That is why they will defend this peace by force if they have to ( 63 ).

He concludes with a Popular Front peroration suggesting yet another reason to join up with the Soviet Union:

Die Statsmänner der Welt, welche ihre Nationen bewogen haben, mit der Sow jetunion ein Bündnis $2 u$ schliessen, waren weitsichtig genug, dies einzusehen. Hach zwei Jahrzehnten ist dieser mächtig entwickelte Riesenstaat zum verläßlichsten Garanten des Friedens geworden. Darum muß ihm die Sympathie jedes freiheitsgesinnten Menschen gehören! Wir stehen alle vor dieser folgenschweren Entscheidung: Entweder Krieg und endgültiger Untergang oder Frieden und Aurstieg.

The Soviet Union is strong: support it and prevent war. That is the message which the Popular Front came to convey.

Graf's speech exemplifies how the Popular Front policy became inextricably equated with the strongest possible support of Soviet policy in all areas. The only way to beat the Mazis was to stand with the Soviet Union. Das wort promoted that equation by depicting a country in which ". . die unsterblichen Ideen von Freiheit und sozialer Gerechtigkeit, von Fortschritt und Humanität verwirklicht werden können! (Graf 60). 


\section{A MATION OF NATIONS}

The idea of a Volkergemeinschaft held great appeal for the promoters of the Popular Front. After all, it was Hitler's total rejection of this concept and his substitution of the idea of the racial superiority of one people over all others which was tearing the political fabric of Europe apart. That was why Hitler was the real enemy rather than Fascism as such. Hitler had made racism a threat to European peace - and to the Soviet Union. If the example of the Souiet Union could convince Europeans that dirferent peoples could live together harmoniously (given the right sort of social system), then Hitler's doctrine could be reruted.

Mumerous articles, poems, and stories in Das wort illustrate and reinforce the idea that in the Soviet Union, old-fashioned nationalism had been transformed by the new state into something positive. Not only were peoples now able to live side by side in peace and rriendship, but now, in the Soviet ramily of peoples, individual nationalities were free to voice and develop their own unique characteristics. The Soviet Union was a new kind of country, a "nation of nations," where each people could cultivate its special heritage, but all were united by the new social and political system. He was a Tadzhik, she a Yolga-German, they Ukrainian Jews, but all were "Sow jetmenschen."

Hugo Huppert elaborates on this idea in his introduction to the Volksdichtung section of the October Revolution Twentieth Anniversary issue of Das Wort (Hov. 1937: 41-44). His contribution, 
entitled "Freiheit und Poesie der Sow jetvölker," introduces an extensive collection of short verse from many of the nationalities of the Soviet Union. He begins with a short anecdote about a holiday trip he had taken to the Northern Murmansk region. Waiting at a rail siding, he had heard "merkwürdiges, ergreifendes Singen" (41). A group of woodcutters had gathered on the train to sing "ihre uralten, wiedergeborenen nordrussischen Heimatchöre." He soon gets to the point of his story: "Der Große Oktober hat das innerlich rreie Volksschaffen auch in der Kunst mit einem Schlag entresselt" ( 41 ). Describing how this "Yolksschaffen" had been suppressed under Czardom, he calls it the "Gemeingut des Yolkes. Nein - der Yölker." During the Revolution the traditions of ". . Yolkspoesie wurden wrederaufgenommen, schöpferisch fortgesetzt "(41). He explains that "Der Sozialistische Oktober hat der Volksdichtung ihren Massencharacter wiedergegeben. Die neue Freiheit erzeugte die neue Poesie" ( 42 ). He is attempting to establish just why the Revolution has created a new situation for the many nations which the Soviets inherited from the Czarist Empire. The old national cultures may now develope in the new socialist environment:

Anknüprend an den gesamten, unausschöprbaren Reichtum der alten, vererbten nationalen Formenwelt - emprängt das zeitgenössische künstlerische Yolkscharfen aller Sow jetnationen und -völkerschaften vom heroischen alltag und Festtag seinen neuen sozialistischen lnhalt. (42)

The forms of traditional culture will survive and prosper by being utilized to express the new socialist reality. This new art is called, after the Soviet model, sozialistischer Realismus. He adds that "In die Kunst bringt diese Intelligenz [who have "come up" rrom the 
workers and peasants] besondere Züge des sozialistischen Realismus, zu dessen Wesensbestand die schöprerisch-kritische Meisterung auch des Volkstümlichen Erbes gehört" (42). What to do with the old culture was one of those issues over which the "Ultra- Leftists" and Proletcultists had split with Lenin. Socialist Realism is the artistic theory which Stalin finally settled on out of those old fights. ${ }^{3}$ The inherited culture will not be rejected, but transformed, by being put to use to express the new society and culture growing daily in the USSR.

Huppert continues by describing how the art of the nationalities is now being used to "sing" about the new themes: Lenin, popular Civil War heros, socialist construction, collectivization and, of course, Stalin. The poems presented in this issue of Das Wort illustrate some of this work. Here is Huppert's own "Nachdichtung" from the Armenian, entitled "Elektrisch Licht im Dorfe":

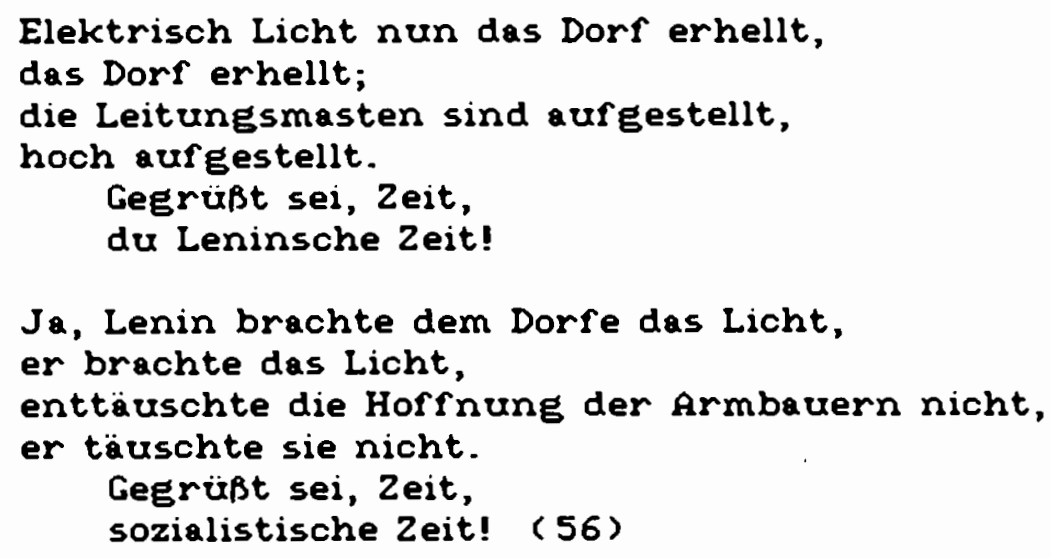

There are two more verses, the refrains ending in: "Kollektivbouernzeit!" and "du Stalinsche Zeit!" This is an example of Soviet reality (rural electrification) being extolled in a traditional form (a song) by a people (Armenian) now free. 
Another example of the new reality in verse is presented in the same issue. It is a poem entitled "Augen..." by Klara Blum, in my opinion the best Communist poet whose works appear in Das Wort. The poem consists of eight four-line verses, mostly of alternating rhymed iambic hexameter and pentameter. Here is some of the poem:

2 wei Augen leuchten auf im Stadtgedränge:

vom fernen Ost ein Schräger schwarzer Blitz;

und Moskaus Bau und Moskaus Menschenmenge

sie spiegeln sich in ihrem klugen Schlitz.

2 wei Augen leuchten auf im Kremlsaale:

sie gießen Asiens Glut in den Bericht;

es spiegelt ihre feuchte Mandelschale

den treuen Lehrer, der $\mathrm{zu}$ ihnen spricht.

.... (Nov. 1937: 118)

Soviet Asians visit Moscow, the Kremlin, Lenin's quarters. In the bad old days their eyes ". . starrten einst gequalt, gehetzt ins Leere / und brannten weh vor Angst und Schmerz und Schmach." They had done so because ". . der - Mongole, der-Tadshik," and ". . die - Armenier waren, die - Osseten, / weil mandelförmig, schräggeschlitzt ihr Blick." Now they can look forward to a bright and brotherly future:

im Gemsenblick Kaukasiens Felsenspitzen vom neuen Licht, vom freien licht erhellt.

Im engen Spiegel unsre Welt, die Weite verschiedne Rahmen, doch das gleich Bild, so taucht ein Augenpar vertraut ins zweite, und brüderlich hat sich ihr Bund erfüllt. (118)

The idea that the new society enabled tradtional culture to not only survive in its old forms, but develope and grow, is dealt with in some detail in marginal note (Oct. 1938: 155-156). Entitled

"Aserbeidshanische Musik," it was contributed by "B.B.," 
presumably Béla Balazs. 4 Describing very successful appearance in Moscow of the Opera and Symphony Orchestra of Azerbaijan, Balasz explains that music which was classical and European in form before the Revolution, while existing in Azerbaijan, had not been in any way associated with the "Volksmusik" of that country. It had simply been a roreign import. Now, however, the Revolution has freed the Azerbaijanian people both "geistig und kulturell" (155).

Furthermore:

Die Nation wollte aber auch ihre eigene Musik über die Grenzen ihrer Republik verbreiten. Nun handelte es sich nicht mehr darum, Yolksmelodien zu verwenden, wie Raubgut aus "exotischen Kolonien" oder sie als besondern Schmuck in europäische Kompositionen zu setzen - nun sollte die musikalische Kultur des bodenständigen Yolks gehoben, seine Schöpferkraft entwickelt werden.

Da brach der musikalische Klassenkampr aus. (155)

Balazs describes the resistance of "nationalists," who did not want native music corrupted by being incorporated into European classical-music forms (155). They raised technical arguments about tones and scales and instruments, and even based their case on Stalin's dictum "Sozialistisch im Inhalt, national in der Form" (155). Anti-socialist motives are imputed to this reactionary resistance. The progressives prevail eventually, however:

Und nun geschah das scheinbar Paradoxe: erst durch den rremden Einfluß befreite sich die spezifisch nationale Musik von den Fesseln der Primitivität, und eine neue Blüte der nationalen muskalischen Phantasie begann. (155)

Balazs asserts that "Die neue Musik Aserbeidshans fand den Anschluß an die europäische und war dennoch nicht weniger national" (55). It was furthermore". . ein Fortschritt und der notwendige Gang der Geschichte" (55). Here was the Marxist speaking. 
Traditional culture would maintain its autonomy, but at the same time somehow meld or amalgamate with the (more advanced, it would seem) European forms. In a marginal note, Balazs did not attempt to elaborate how this process occurs. Instead, his conclusion is a fascinating comparison of the treatment of folk musik by Liszt and Brahms on the one hand, and Bartok and Kodaly on the other. The latter had "saved" musical forms which were dying - folk songs and tunes from remote regions - by transforming them in the medium of Western music, producing new forms drawing on both sources. Liszt and Brahms had merely incorporated some good tunes into their own kind of music, whereas Bartok and Kodaly were able ". . den spezifischen Character, das Aroma dieser Musik zu bewahren" (156). The young Azerbai janian composers have not got there yet, Balasz is saying, but they are on their way.

This article is as an excellent example of the thought processes of the Communist Kulturpolitiker. Soviet power and centralized authority is able to put down reactionary elements among the various nationalities and allow progressive elements to reach beyond the parochial limits of their cultures and create something better using the culture they have inherited, their Kulturerbe, but not being chained to it. Thus the nations of the Soviet Union benefit from Soviet power not only by improvements in industry and agriculture and living standards, but their intellectual and cultural life is also transformed for the better.

But it was not only the peoples of the Asian, or Moslim areas of the Soviet Union who were reaping the good harvest of the 
Revolution. Other groups also thrived in the new society. Klara Blum, whose poem we examined above, wrote poem and a Reportage about the Jewish settlements in the Ukraine. The poem, "Weingarten im jüdischen Kolchos" (Oct. 1938: 74-75), is followed in the next issue by an article which is actually an explanation and elaboration of the poem (Nov. 1938: 69-72). Written in the same verse form as Blum's "Augen...." the poem's 10 stanzas describe proud Jewish collective farmers tending their vineyards. Their new life suits them:

Schimmernd unter Blättern reift der Wein. wieder wird die Ernte reicher sein, wir ersinnen immer neue Wege, daß er schöner blüh durch unsre Prlege. ( 74 )

Characteristics of their people long held against them - and rightly so under the old order - now benefit them and find digniried and honorable application. The old religious impulses are now better utilized as well:

Scharfsinn, unsrem Volke angestammt, lang zu fruchtlos leerem Spiel verdammt, zu des Händlers schmachwoll kleinen Listen, zum gespitzten Wahn des Talmudisten -

er, der einst gekrümmte, wurde grad, sinnt auf Blatt und Frucht, auf Werk und Tat, stillt mit klugem Einfall jede Wunde und steht fest auf seinem eignen Grunde. (75)

The old nemesis of the times of the pogroms, the Cossacks, are now their friends: "die Kosacken aus den Dörfern droben / kommen, nachbarlich ihr Werk zu loben" (75). Soviet power has done all this: "Wo das Volk regiert mit seinen Räten / darf man Völker nicht mehr niedertreten" ( 75 ). She concludes her idylle on the new life with a reference to the new-found pride of the Jews: 
endlich losgelöst von Schmach und Trauern:

hier im Land der freien Judenbauern. (75)

The Reportage which appears in the following issue elaborated and expanded on the themes of the poem (Nov. 1938: 69-72). The title, "Auf jüdischer Erde," echos the idea that the Jews are much better off now working in an agricultural commune on their own land, rather than in their previous city occupations or as the serfs or peasants of Czarist Russia.

Blum praises the ".. subtile[n] Achtsamkeit" with which ". . die sow jetische Nationalpolitik jedes einzelne Volk behandelt" (69). Under the new regime, there need be no more pogroms. She explains ingenuously: "Es sind einfach die Herren nicht mehr vorhanden, in deren Interesse es lag, Uölker gegeneinander aufuhetzen" ( 69 ). The Jews speak with one another in "beinahe klassisches Jiddisch, ähnlich dem, das im Moskauer Jüdischen Statstheater gesprochen wird" ( 70$)$. All those old traits, the "Scharfsinn, Kombinationsgabe, Findigkeit," derided by gentiles in the old days, now are usefully employed - in the vineyard (70).

The two village synagogues are now a school and a club; "Den gläubigen $J$ uden ist natürlich die Möglichkeit geboten, frei und unbehindert ihre religiösen Bräuche zu prlegen" ( 72 ). Blum qualifies that with: "Aber die Entwicklung der jungen Generation führt sie unverkennbar von der Religion fort und der Wissenschaft $2 u^{\prime \prime}(72)$.

She concludes her article by castigating Zionism. Professor Weizmann says the Jews in the Soviet Union have become "entnationalisiert" ( 72$)$. The Jewish-Ukrainians refute this idea; the Jewish national aspirations have been realized in the Soviet 
system. The Soviet Jew looks over to Germany and: "In dem unglücklichen Bruder erkennt er seine überwundene Vergangenheit wieder, wie der andere im glücklichen Bruder seinen verwirklichten Zukunftstraum" ( 72$)$.

Not surprisingly in a journal intended to be read by a primarily German audience, the Volga Germans received quite a lot of attention. These were descendants of German settlers who had been invited to inhabit and cultivate land in the Ukraine in Catherine the Great's time. They now possessed their own Autonomous Republic. 5 Their capital, Engels, was across the Volga river from the large Ukrainian city of Saratov. The promulgation of the new Constitution of the Yolga German ASSR was the occasion for visit by several German writers to Engels ( $\mathrm{July}$ 1937: 98-102). Their reports also appeared in that issue, in conjunction with extensive extracts from the new Constitution. These reports are typical of Das Wort's coverage of the Yolga Germans.

Fritz Brüghel reports in his "Die deutsche Nation an der Wolga" (100) that:

"Nun sind diese Deutschen sozial und national zu freien Menschen geworden: sie leben in vollkommener Freundschaft mit Russen, Kasachen, Tataren zusammen; keine der Nationen, die hier untereinander leben, glaubt höher oder geringer $z u$ sein als die andere. (100)

For the Germans, that is clearly quite a contrast with their cousins in Europe. There is nothing, it would seem, intrinsically wrong with Germans. Here they live in peace with their neighbors.

Julius Hay is enthusiastic about his reception in Engels and the Yolga Germans' growing cultural life: "Diese Tage waren für Engels 
Tage konzentrierten kulturellen Lebens" (101). In the State Theater, at concerts and presentations by Young Pioneers and the pupils at the rlight school, everybody had done his best to entertain the guests. They have been invited to a special session of the Central Executive Commitee of the Republic, which had been discussing the new constitution. "Und daß diese Menschen Deutsche waren, war dem deutschschreibenden Schriftsteller eine große, unvergeßliche Freude," concludes Hay (101).

"Seid gegrüßt, junge Rekruten unserer ruhmreichen Roten Armee!" is how Willi Bredel begins his account of young "Sonnengebräunte, kräftige deutsche Bauernburschen und Jungarbeiter" serving in the Red Army (101). It is a story which should be better known around the world, "vor allem in Deutschland" ( 102 ). These Germans have an honorable revolutionary heritage, in the October Revolution, in 1905, in Pugachov's rising during Catherine the Great's reign. In the faces of all the young recruits was this question for the German writers visiting Engels: "Ja, aber wissen denn die Deutschländer so wenig von uns? Wissen sie denn nicht, wie wir leben, was wir schaffen, welche Freiheiten und Rechte wir Eenießen?" ( 102 ). No, they do not, replies Bredel to this plaintive look. If they did," . . würde es sie mächtig anspornen, das faschistische Joch so schnell wie nur möglich abzuschütteln" ( 102 ). 


\section{THE PEOPLE GRERT AND SMALL}

The Bolshevik revolution brought a new society to Russia. But a society consists of individual people, great and small. Das Wort showed how the common people of Russia had been transformed politically and culturally by the Revolution. And more than a little space was devoted to extolling the virtures of the new leaders of the country, whose "leading role" in society was a product of their political wisdom and inderatigable activism in the interests of all.

The Russian of yore, oppressed, sullen and and slow, had become a "new man." The common people of the Soviet Union, the "just plain rolks," had become heroes in the new society, no matter in what sort of activity they were engaged. Women have benefited from socialism equally, if not to a greater degree, than have men. "Von alten und jungen Frauen" shows both older and younger generations of women reaping the benerits of the new order (Oct.1938: 153-154). Bela Balkzs begins this marginal note by remarking that "in der Sow jetunion ist eines der ärgsten Schimprwörter: 'Nye ssosn jat jetlni tschelov jek," translated by Balazs as "ein nicht bewußter Mensch;" for Russians that is more or less the same as "eine Grobheit wie 'n je kulturny' [ist], was etwa 'kulturlos, rlegelhaft' bedeutet" (153). Such terms are instructive, they tell us much about what is going on in a society: "Begriffe wie 'Bewußtsein' und 'kultur' haben in diesem Lande eine hohe moralische Bedeutsamkeit erhalten" (153). The Chairman of the City Council of Istra, a small town not far from Moscow, tells Balazs that the old women of Istra have been 
transformed. Previously "diese alten Weiber saßen hinter inrem Garten wie in dunklen Höhlen." Now they take an active interest in the city, they have formed "Straßenkomitees zur Überwachung der Sauberkeit" (153). The Chairman exclaims to Balazs that the old women "werden bald ganz 'bewußte' Menschen. Auf Ehrenwort!" (153) Balazs intimates that the Revolution has brought the babushki of yore a social conscience which they did not possess previously. And what holds for old women is certainly so for younger, in the new Russia. Andrey, a stong young carpenter, is very impressed by the female agronomist who leads his kolkhos (collective farm). Playing the devil's advocate, Balazs queries Andrey: "Da scheint Ihr ja ein Frauenregiment in eurem Kolchos zu haben?" "Gewiß!" replies the carpenter "geschmeichelt, stolz" (154). His wife is the cashier and bookkeeper. The Revolution has effected a change in the deepest felt attitudes of Russian men towards women. Yolodya, a fifteen-year old student, sees nothing strange in the fact that every group of students in the May Day parade was led my a girl. "Die Mädchen lernen ja viel besser" is his ingenuous explanation (154). Balazs rhapsodizes: "In diesem Lande hat man mit der Sturheit und Kulturlosigkeit endgültig abgerechnet. Es gibt nur eine Parole: Lerne, vollkomme dich, werde ein 'bewußter' Mensch, ein 'ssosn jatelni Tschelou jek'!" (154)

F.C. Weiskopf witnesses a touching and emblematic little scence on December 5 on a dark Moscow street ("Blätter aus einem Moskauer Tagebuch," Jan. 1938: 60-61). In a fine cold rain everybody is in a hurry, they are not even stopping to peer in the display windows at 
the shops. All but one: "Nur eine einzige Frau, eine Alte in ruppigem Pelz und hohen Bauernstiefeln, steht vor einer Auslage, - und die ist leer" (60). Empty? wonders Weiskopf. Upon closer inspection, it seems not. The old lady is looking at a map of the country with pasted-on pictures of the latest achievements: the new city of Komsomolsk, tea growers harvesting their crop in the Caucasus, huge 5-motor airplanes flying in formation. In a large area in the middle of the map "heben sich schwarze und rote Buchstaben ab:

'Yerfassung. Grundgesetz der UdSSR. Artikel 6..." (61). She is struggling to read the lines, picking out the letters one by one. "Schwere Arbeit, das Lesen, Großmutter?" inquires Weiskopr. Difficult all right, but "wenn du erst einmal herausbekommen hast, was für Worte da stehen, dann ist alles andere leicht" (61). She tells him that it used to be that the laws were just "'kitajskaja Eramota" - chinesische Schriftzeichen," but now "es wird über unsereins und seine Sache Eesprochen!" (61) "Unsereins" is "unser Bruder" in Russian; "und so meint es die Alte wohl auch; sie meint sich selbst und unsern Bruder und die brüderlich gemeinsame Sache" (61).

Among the most popular Soviet heroes of the Thirties were explorers and inventors. The Soviet Union began a very active program of arctic exploration in the mid-Thirties. Typical of the Soviet books published about these exploits is Michael Yodopianov's novel Der Traum eines Piloten, reviewed for Das Wort by Maria Arnold ("Die Eroberung des Nordpols," July 1938: 137-138).

Vodopianov is a pilot who organized and carried out an exploration of the North Pole by airplane in 1937. His novel not only served as the 
basis for the actual planning for this expedition, but was made into a play, which opened on the same day its author landed at the North Pole (137). Arnold praises the Soviet pilot and his crew. They have become "Pioneere[n] der Wissenschaft;" Yodopianov ist "ein Mensch des sozialistischen Staates" who has dedicated "seine Scharfenskraft der Aurhellung eines bisher nicht erforschten Teiles unserer Erde" (138). The unstated message of these remarks is that technology is a very positive thing when utilized to good ends, rather than, say, for military science, as in a rearming Germany.

Iwan Goll provided for Das Wort "Auszüge aus einer Kantate," which panegyrizes the exploits of the crew of an arctic exploration vessel ("Tschel juskin," Feb. 1938: 63-68). The ship, attempting to sail from Leningrad to Yladivostok through the Polar Sea, was destroyed by drift ice. The crew had to abandon it and set up camp on the ice floe. Aside from further illustrating the importance given to the theme of heroes of exploration by the editors of Das Wort, this work is interesting from an formal point of view. It is apparently an attempt to utilize a genre inherited from the German Kulturerbe, the cantata, for a modern socialist subject; in other words, socialist in content, (German) national in form.

Goll's work is modelled after church music such as Telemann's Der Tag des Gerichts or Bach cantatas (or Faust for that matter), in which God and the devil dispute whether the soul of man is good or bad. In this case, it is "Der junge Chor" and "Der alte Chor" who set out their viewpoints in the first section: 


\section{THESE}

Der junge Chor:

Der alte Chor:

$$
\begin{aligned}
& \text { Groß ist der Mensch, } \\
& \text { Beherrscher dieser Erde! } \\
& \text { Er trägt die Urgebirge ab, } \\
& \text { er lenkt die alten Ströme um, } \\
& \text { und aus den eroberten Himmeln } \\
& \text { vertreibt sein brausender Flug } \\
& \text { die sterblichen Götter! }
\end{aligned}
$$

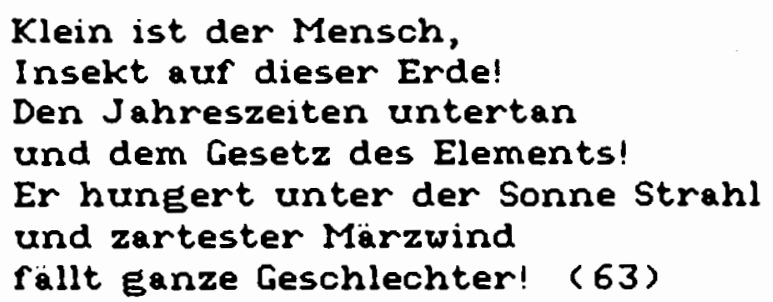

Two more verses in the same vein are followed by "Der Reporter" stepping rorth with:

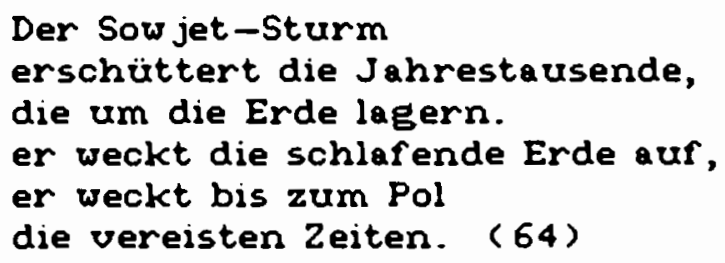

"Das Lied vom "Genossen Schiff" ("Genosse Schiff, / mein bester Kamerad!") (65) is followed with the reporter again, then "Das Lied vom Gefährlichen Leben," (66) another "Reporter," (67) and the grande finale in "Ballade der 104" (68), evoking the gallant crew's establishment of a camp on the ice floe:

Hundert und vier bauten in einer Nacht ein neues $R$ ußland:

Wie der treibende Erdblock

Heimat im Reich der Planeten -ward der treibende Eisblock Heimat im Sturme des Pols

Hundertundvier histen am Ende der Welt die rote Fahne des Lebens! 
Praise of the Soviet Union obviously went beyond all bounds of taste and quality. Form was form, but the content was all that really mattered, as long as that content were limitless admiration and approval of the people, the policies, and the leaders of that country.

The cult of the personality, unlimited leader-worship, reached its apogee during Joseph Stalin's rule in the Soviet Union. But it was not a new phenomenon out of the blue in the Soviet world. Vladimir Lenin shortly after his death began to rise to the status of Soviet sainthood. By the Thirties he was certainly there. Das Wort published both Soviet writings in translation and original literature about these heroic leaders of their host country.

Vladimir Mayakousky's "Wladimir Il jitsch Lenin" is more interesting than most of the laudatory poems generated by Soviet writers appearing in Das Wort ( $J$ an. 1939:66-69). It is infused, as are all these poems, with an aura of sanctity. A study of this genne (Lenin and Stalin worship) would reveal more in common with medieval hagiography than with more modern forms of literature. A few lines will suffice as example:

Er kannte

Schwächen wie wir sie kennen.

Er wie wir

überwand Krankheiten.

Sagen wir

mir: ein Billard, das Auge zu schulen, das Schach aber ihm von größerem Mutzen rür Führer. 
erhob

zu Menschen

die Bauern von gestern,

so schus er

die Diktatur der Arbeiter-Menschen

über den Gerängnisturm

des Kapitals. (67)

"Folklore um Lenin (Nach dem Russischen)" by Peter Nikl is a short collection of verses apparently composed by Kirghisian,

Turkmenian, and Siberian poets (Mar. 1937: 33-34).

Here is a sample:

\section{DER GLAN2}

Aus Lenins hugen brach ein solcher Glanz, dab selbst die Seelen der verstorbnen Reichen noch aus dem Paradies vertrieben wunden. So ist es! Selbst das Paradies erbebte.

Als Lenin alle Reichen mit dem Hammer schlug.

(kirgisischer Sang, gefunden 1925) (33)

The ubiquitous Johannes $R$. Becher made a contribution to Lenin

lore in the December 1938 issue:

\section{LENIN IN MÜHCHEN}

Mir ist es so, als sei e $r$ es gewesen -

Es war ein Tag wie heut, so sommerklar.

Er saß auf einer Bank und hat gelesen.

Ich war der Hauptmann einer Räuberschar.

Wir jagten heulend durch die Isar-Auen -

Da saß auf einer Bank gebückt der Mann,

Um kurz von seinem Buche aufzuschauen,

Als sähe er durch uns hindurch, und sann.

Ein Räuber warr nach ihm mit kleinen Steinen.

Ich nahm den rest und drohte finster. "Laß, Er liest und träumt! Was soll er von uns meinen?

Was? Ich verbiet es dir! Ich mach nicht Spaß! 
Damit wirst du dir keinen Ruhm verdienen!"

Ich ging zur Bank und nahm die Mütze ab:

"Mein lieber Herr, der Steinwurf galt nicht Ihnen, Verzeihen Sie, daßs ich gestört Sie hab."

Er schaute wieder aur von seinem Lesen

und lächelte. Ich sah, daß er schrieb..

Mir ist es heut, als sei e $r$ es gewesen

Mit seinem Lächeln, das lang in mir blieb, [sic] (Dec. 1938: 23$)^{8}$

Stalin-worship is less prevalent in Das Wort than is that of Lenin. When it does appear, however, it is intense. The October Revolution Twentieth Anniversary issue is an example. For that issue, Olga Halpern provided a translation of a short story by $F$. Panferow entitled "Kirill wird in den Kreml befohlen" (Nov. 1937: 11-19). To get us into the mood for that story, presumably, on the page facing that story is a poem translated from the Spanish by Erich Weinert. Stalin helps and inspires those in need, and he is close to the land and the common people. Here is the poem:

\section{STALIH}

\section{von \\ Sancho perez}

Stalin wohnt im Land verschneiter Wälder, wo die Menschen Irei wie Adler sind.

Stalin fragt uns: und das Korn der Felder, warum nehmt ihrs nicht für Weib und Kind?

Stalin sagt: Daß eure Kinder lachen, gebt den Kindern Sonne, Frucht und Brot! Mutter, mein Gewehr! Wir werdens machen! Stalin sagts: Er hilrt uns aus der Hot.

"Stalin?" sagte die Mutter. "Unser Yater sprach so oft von ihm, ich weis noch gut. War wohl Yaters Duzfreund und Berater? Wenn er von ihm sprach, das gab ihm Mut." 


\begin{abstract}
Wenn ich nun im Kampfe erschossen werde, Bruder, nimm mein Koppel und Gewehr!

Stalin sagt es: Euer ist die Erde!

Nehmt sie, und sie nimmt uns keiner mehr!

Stalin denkt an vieles, das noch werde.

Ist er noch so weit, er ist doch hier.

Beide lieben wir die Eleiche Erde.

Wenn wir siegen, steht er neben mir.
\end{abstract}

F. Panferow's story is a vignette of Sozialistischer Aufbau (Nov. 1937: 11-13). Kirill, director of a tractor station, is called to Moscow for an interview with Stalin himself. The leader wants to discuss a plan for regional development which Kirill had submitted a year earlier. Kirill, a real Mensch of the people, departs from his wife St joschka in touching scene: "Den Namen Stalins erwähnten sie nicht. Sie sagten "er" und "bei inm" und waren so aufgeregt, daß St joschka vergaß, dem Kirill Mantel und Wäsche mitzugeben" (11). Kirill decides to not to wear his medals into Stalin's presence because Stalin himself "ganze Fronten befehligte er, einen genialen Plan zum Zerschlagen des Feindes hat er entworfen - aber einen Orden trägt er dennoch nicht" (11).

Before meeting Stalin, Kirill has a fascinating conversation with Sergej Petrowitsch. They are acquainted: Kiril had once sat under indictment before this man "wegen des großen Trinkgelages in der Breiten Schlucht" (12). Sergej Petrowitsch is annoyed with a certain lack of toughness and determination which he has discerned among the Communists leading the revolution at the lower levels. Hard times are coming: "Raufen - bald beginnt das große Raufen," he predicts (13). "Einige spielen sich da als Kulturapostel auf. Diese Kerle ohne Saft und Kraft! Man muß auf sie aufpassen. Scharf!" (11). The 
unstated background for these remarks are the purges and show trials. Kiril's erstwhile judge castigates those who are "weder kalt noch warm;" a certain Sharkow is suspect, a "Gebietssekretär, . . " who "im Kampf gegen Trotzki hat er weder kalt noch warm Stellung genommen" (13). Such an attitude is clearly not the required one for the times.

During this ominous conversation, Stalin slips into the room unobtrusively, "beherrscht, ohne überflüssige Bewegungen der Hände, des Kopfes, des Körpers" (14). Stalin is gemütlich: "Schau an - das sind Pranken! Lebt deine Mutter noch?" (14) Kirill is

flustered and impressed, and observes Stalins face closely; he sees there "nichts Auffallendes, nichts Besonderes" (15). Stalin's eyes are now sad, now severe and pitiless, now sparkling and jotting from object to object in the room (14). A remarkable image now suggests itself to Kirill to describe Stalin: he is like Mount Elbrus in the Caucasus, so huge that it seems to be nearby even when it is over a hundert kilometers away. "Ja, es gibt auch solche Menschen: sie scheinen neben dir $\mathrm{zu}$ sein, so $\mathrm{zu}$ sein, wie $\mathrm{du}$ bist, aber $d u$ reichst und reichst nicht an sie heran!" (15)

Stalin's language is that of the people, of Kirill himself:

"0-0-0. . . so ist er also!" Kirill schien es, nein, er war vollkommen überzeugt davon, daß alles, was Stalin sagte, auch ihm, Kirill Shdarkin eigen war, daß er selber, Kirill Shdarkin, das schon irgendwo gesagt hatte. Gleichzeitig war er sich aber dessen bewußt, daß er niemandem ähnliches gesagt hatte, daß es ihm nur darum so schien, weil Stalin mit klaren Worten jene Gedanken assprach, die seinen nah verwandt waren: diese Gedanken hatten nur bei Kirill nicht jene Worte gefunden, die jetzt Stalin für sie fand." (16) 
Here is a significant difference between the images of Lenin and Stalin. We saw in Becher's poem, for instance, that Lenin is remote and scholarly, an far above common people in the quality of his thoughts, which are devoted to be sure to the good of the people. He is a man before whom one adopts a respectrul, almost reverent attitude. Stalin by contrast is a man of the people, one of us, he speaks our language and understands our needs. His power and leadership derives from that kinship to the common man of Russia. Here is a kind of Soviet Führerprinzip:

"0-0-0 . . . so ist er also!" rief Kirill wieder in Gedanken, und zum erstenmal verstand er Ganz klar, daß die Größe Stalins sich aus Millionen von solchen, wie er, Kirill Shdarkin, zusammensetzt und das Gefühl der Unerreichbarkeit, das Kirill bisher gehemmt hatte, verschwand gänzlich; ein neuer Stalin erstand vor ihm: der Stalin, den er vom Herzen des Volkes her kannte, von der Front her, aus dem Kampr gegen die Feinde des Volkes. "Unser bist du . . . unser... von unserem Blut ... das ist es!" (16)

Stalin goes on to tell Kirill how "der Feind . . benutzte die Schwankungen der Bauern," or that the revolution has no need for "solche saft- und kraftlosen Leute; die können keine Revolution machen. Pfannkuchen können sie machen" (17). Just who does Stalin have in mind here? No details are given.

Perhaps we can taste in this story some of the atmosphere of paranoia and uncertainty which prevailed in the Moscow of the mid-Thirties. They had to be "holier than Thou" when it was a matter of presenting the USSR and its leader. It was not healthy to be "saft - und kraftlose Leute" in the Soviet Union of Joseph Stalin.

As for Kirill, Stalin, after chiding him a little for incipient softness in quelling a disturbance among the peasants in his region, 
grants Kirill a reduced, but substantial sum of roubles to build a small damm. "Das ist ein Wirt!" exclaims Kirill, marvelling at the leader's peasant cleverness (19). The money is no gift, explains Stalin: "Sollst aber nicht meinen, daß wir sie [the money] schenken! Nein, wenn ihr reich werdet, bezahlt inr sie mit Prozenten" (19).

There is promotion in the air for Kirill as well. He ought to consider traveling abroad some, and ". . Sollen wir dich vielleicht an ein neues Lenkrad setzen?" muses Stalin (18). Kirill's lack of medals also attracts Stalin's sharp eye:

"Ach, hast du einen Orden? Warum trägst du ihn nicht?" "Und Sie? Warum tragen Sie keinen?"

"Ich?. . Hm, das ist was anderes. Ich hab ihn mir nicht verdient" (19)

Humility and a touching self-effacement are added to his considerable list of virtues. As Kirill shuffles out the Kremlin gates in a daze, he muses:

"Und was will er mit mir tun? Das Lenkrad wechseln?. . . Bald kommt das Rauren? Ach, soll er mit mir tun, was er will! Ich vertrau mich ihm bis zum letzten Fäserchen an." Kirill ging mit resten Schritten, seine Stiefelabsätze klapperten laut auf dem Asphalt und sein ganzes Wesen rief: "Seht mich an! Ich war bei Stalin!" (19) 
NOTES TO CHAPTER IY

1 Stalin's article "A Year of Great Change," which appeared in Pravda on November 7 , 1928, is considered the turning point from the previous NEP policy. Stalin "officially" announced the "new revolution" a few weeks later. By 1935 Socialism was pronounced to be "achieved and won" (Heller 232 and $277 f f$. ).

2 Mikhail Heller's Utopia in Power is filled with the gruesome statistics ( $232 \mathrm{f}$.). Slonim's account shows how literture was mobilized to promote Stalin's plans for industrializtion and collectivization (Soviet Russian Literature 155r.).

3 Slonim's account of Socialist Realism in Russia 15 a good introduction, expecially the relationship between Stalin's plans for industrialization and the role literature was to play (Soviet Russian Literature 155r r.) Socialist Realism is the aesthetic theory which explains how literature is to actively participate in the renovation of the country. A more detailed work, with documentary material, is James C.Yaughn's Souiet Socialist Realism. For the East German perspective, see Schlenstedt's Wer schreibt, handelt, and Zur Tradition der sozialistischen Literatur.

4 An Hungarian film-director and art critic, he was one of a conterie of Hungarians long associated with the German Communists, including George Lukacs and Andor Gabor, who had fled Hungary along with Bela Kun after the collapse of his short-lived Hungarian Soviet Republic. A very detailed account of his life, including photographs and much fascinating material about Balasz' Soviet exile, is Joseph Zsurfa's Bela Balazs, the IIan and the Artist.

5 The Yolga German ASSR was liquidated in August 1941. Its inhabitants were deported East and to the far North (Heller 379 ). Heller and Nekrich write: "The Volga Germans were accused of collaborating with Kazi Germany, when in fact they were among the most loyal inhabitants of Russia" ( 379 ).

$8 \mathrm{Jürgen} \mathrm{Rühle} \mathrm{reatures} \mathrm{an} \mathrm{interesting} \mathrm{discussion} \mathrm{of} \mathrm{the}$ differences in quality between Becher's early output and his later work ( Literature and Revolution 265rr.) Becher became the Minister of Culture in the German Democratic Republic. 


\section{CHAPTER $\Psi$}

\section{CULTURE IN THE NEW SOCIETY}

"Es gibt auch ein Land, wo die Schriftsteller an der Leitung des Staates teilnehmen - wie übrigens auch die Köchinnen, - wie übrigens alle, die mit den Händen oder dem Kopf arbeiten". That is how Mikhail Koltsow opens his discussion of the role of writers in the new Soviet society in his address before the II. International Writers Congress ("Sow jetunion," Das Wort, Oct. 1937: 68). Writers are to work hand in hand with other elements of society to form the new clvilization. He disputes any kind of "Ausdruckstheorse," whereby writers are simply expressing something welling up from within them without particular reference to the surrounding world (69). Instead, the "Gefühle und Stimmungen" of writers are not "von innen her geboren, sondern die Geistesverfassung der Yölker und Klassen, ihr Streben und Hoffen, ihre Enttäuschung und Empörung zum Ausdruck bringen" (69). And in some cases, writers must even lay down their pens temporarily and reach for a gun, as in Spain ( 70$)$, where the Conference was taking place. The role of the writer 15 a critical and active one in a revolution and the creation of a new society. Koltsov asserts that in the Soviet Union, the problem of the role of the writer in society has long been resolved, unlike in the capitalist countries (72). The writer there is the "führende[n] Mitschaffer der neuen Gesellschaft. Mit seinen Werken beeinflußt er das Leben 
unmittelbar, treibt er vorwärts und verändert er es" ( 72 ). Culture is not merely an expression of a people, but is something which will be directed consciously and created rationally by writers and artists. They must be "rür oder gegen," they cannot stand above the struggle for a new society $(72)$.

Das Wort chronicles the process of transformation in the Soviet Union. And just as Das Wort was truing to "save" the positive elements of the old German culture from the Mazis, the Soviets have taken the best from their own Kulturerbe.

\section{THE RUSSIAN CULTURAL HERITAGE}

An important element in the Soviet cultural program was the acceptance and promotion of those parts of Russian pre-revolutionary culture which were considered positive and progressive. Partly this effort was in line with Marxist literary theory, which postulated that any popular and revered literature and art was so because it was volkstümlich (Pike German Writers 265). Such art tapped into the essence of a people. It expressed its inner drives and feelings and was an integral part of a people's culture. Acceptance of the kulturerbe was also a quite practical matter for the communist cultural politicians: they could not simply ignore genuinely popular writers and artists of the society they had supplanted; they needed to incorporate them, to "capture" them for the new society they were building.

The works of Alexander Sergeyevich Pushkin were, and have remained to this day, immensely popular among the Russian people. 
There was little need to exaggerate to bring Pushkin into the revolutionary and progressive tradition, since his biography and work certainly expressed the poet's dissatisfaction with the Russia of his day and his desire to see something better.

Typical of the pieces which appeared in Das Wort about this famous Russian poet is Hugo Huppert's essay to commemorate the looth anniversary of Pushkin's death. (In Memoriam: Puschkin," Jan. 1937: 84-87). Huppert points out Pushkin's ideological identity with the Decembrists, noblemen who led an abortive revolt aganst the new Czar Nikolas I. on December 26, 1825 in Saint Petersburg ( 85). Although Pushkin did not participate directly in this affair, his calls for liberty had inspired the consipirators. Huppert differentiates Pushkin from the Decembrists, however, and fits him into more Marxist scheme of things: "Freiheit, Vernunft, Gesetz - sie klangen in den Oden des jungen Puschkin noch abstrakt-aufklärerisch. Dieselben Begrifre kehren nach dem Jahre 1825 anders wieder: bürgerlich-liberal" ( 85 ). Despite Pushkin's aristocratic background, then, he is a Eroundbreaker for the bourgeois revolutionaries of the 19th century, who were progressive in the Marxist sense of the word because they represented the vanguard of their class in its struggle for liberation from the aristocracy. Huppert explains: "Denn immer kommt das Führende und Bleibende in der Kunst aus junger, aursprießender Klassenkraft; und hier war es die Bürgerliche" ( 84 ). Huppert stresses Pushkin's historical stories and plays about Peter the Great and Boris Godunov, who Stalinist Marxist theory now viewed as progressive. Among the qualities which made Pushkin great 
Huppert cites "die vollendete Sprache der russischen Klassik" (84), and "die geformte Fülle des nationalen Bewußtseins" ( 84 ). Huppert's piece is filled with the buzz-words so favored by the Communist culture workers: "volkstümlich vermenschlichten Vaterlandsbegriff (85) ... die frühe Spielgelung der aufgehenden humanistischen Sonne?! (84) . . Gesamtgut der befreiten Völker ( 87 ) . . er war als Bürger ein Yolksmann ( 84 )."

Huppert also points out contradictions in Pushkins outlooks, when he was unable to overcome his class background. He was a nobleman when he rejected capitalism (in the Marxist view, a progressive development at the time ); he exhibited a "bürgerlich-progressiven Geist[e]" in his opposition to serfdom (86). He shared this "treibender Grundwiderspruch" with Leo Tolstoy. (86) Pushkin, however, "löst ihn [the contradiction] immer noch in seiner Kunst: als Realist und Optimist" ( 86$)$. In this respect, he was, in Belinski's words, the "Genius und Ahnherr[n] der großen russischen Literatur" ( 86 ). It is into just this tradition that the communists meant to tap with essays such as Huppert's.

Huppert mentions Tolstoy in his piece. Here is another figure of such grand proportions that the Communists had to accept him and demonstrate how he was also precurser of their own movement. Although Tolstoy was also of the most noble pedigree, Das Wort stressed his ability to capture the essence of the people, the Volksgeist if you will. George Lukros' typically theoretical contribution "Der plebejische Humanismus in der Ästhetik Tolstojs" is an example of this approach to Tolstoy (Sep. 1938: 115-121). 
Lukacs summarizes Tolstoy's aesthetic writings as an attack on modern bourgeois art; his criticism of modern art has been interpreted by epigonal critics as an attack on all art in Eeneral. Not so, says Lukacs: Tolstoy assailed the art of his day because it had "die Verbindung mit den groben Problemen des Lebens verliert" (116). Why had art lost this connection? According to Tolstoy, ". . die Kunst aufgehört hat, Sache des ganzen Volkes zu sein" (Lukács italics) (116). This argument leading to that old Shibboleth among the Communist intellectuals, Volkstümlichkeit. But before getting to the heart of his argument, Lukacs dismisses as "nicht mehr besonders aktuell" criticism (Marxist, presumably) of Tolstoy for his view that modern art had gone astray because it had abandoned religion ( 117 ). No, says Lukacs, that is not the important thing about Tolstoy's Kritik. It is instead what Lukacs calls "der bäuerlich-plebejische Humanismus der Tolstoischen Ästhetik" (117). Lukács concedes that this terminology appears "etwas paradox", since Tolstoy himself was highly critical of humanism and ascribed to it most of the problems facing the modern world (118). But Lukacs obviously knows better than Tolstoy himself what he was really trying to say:

Aber das ändert nichts an der Tatsache, daß die Grundlinie seiner Auffassung der Ästhetik an die Broßen zentralen Probleme der Ästhetik des Humanismus anknüprt; daß er einer der wenigen Menschen seiner Zeit war, die diese Traditionen in ihrer Weise lebendig zu erhalten und eigenartig weiterzubilden versuchten. (118)

And what were those traditions, according to Lukacs? "Es handelt sich dabei um die Yerteidigung des Menschlichen gegen jene Deformationen, die die kapitalistische Zivilisation notwending mit sich 
bringt" ( 118 ). In other words, Tolstoy was a Marxist even if he did not know it. That may seem flippant, but it is in fact the basic idea underlying the entire Kultunerbe idea for the communist critics. All the really good artists and writers were the "Marxists" for their time in that they represented the progressive and revolutionary tendencies inherent in the march of history, just as the Marxists and Communists of our day do. The many articles in Das wort dealing with German literary history exhibit the same tendency to (re)discover and reinterpret the German cultural heritage as an inevitable progression toward the socialist future which is now being realized in only one country - the USSR - but soon will be coming to the fore in all countries.

Lukacs continues his analysis of Tolstoy's aesthetics by pointing out that Tolstoy wanted an art which "rür einen Bauern mit unverdorbenem Geschmack sei es möglich, in der Kunst das Echte vom Unechten zu unterscheiden" (119). Lukacs borrows an image from Schiller to explain what he means: "Damit hat Tolstoi die Molienesche Magd wieder zur Richterin der Kunst erhobenn (119).' Schiller's "naive" artist had early on discovered Volkstümlichkeit, which is the essence of all true - and progressive - art (119). Lukacs, perhaps to explain the function of such non- $r a g d$ critics as himself, hastens to point out that modern Volkstümlichkeit is more rarified than that of Schiller's time: ". - die Molieresche Magd hat rür sie [modern art] die Kompetenz wirklich verloren" (119). Hevertheless, the principle is still the same.

Only in the Soviet Union has this idea reached its culmination 
with the Bolshevik revolution. Here is how Lukacs puts it

In diesem Zusammenhang erscheint der Bauer, der, nach Tolstoi, die Kriterien der Kunst besitzt und die Kunst richtig beurteilt, als ein historisches Verbindungsglied in jener Kette, die von der Moliersschen Magd $2 u$ jener Köchin Lenins führt, die den Stazt verwaltet. (120)

Pursuing the idea of Volkstümlichkeit, Lukacs then makes a most revealing statement:

- . die wirkliche Volkstümlichkeit der Kunst - die volkstümlichkeit der wirklich groben Kunst - entsteht auch im Sozialismus nicht von selsst! Man muß um sie kämpren; man muß zu ihr erzogen werden. (120)

The mentality of the Communist Kulturpolitiker is blatently revealed in this remark:

"Und zwar müssen nicht bloß die Leser zum Yerständnis und Genuß der bedeutenden Werke des künstlerischen Erbes erzogen werden, sondern auch die Schriftsteller, auch die Kritiker, die Theortiker der Kunst. Die schädlichen überreste des

Kapitalismus im Bewußtsein der Menschen trennen uns von der großen Kunst der Gegenwart und 2 ukunft (121).

Who is to do this job, the fighting and the educating, if not those who already are in the know, the Communist writers - and the Communist literary and artistic runctionaries. It is clearly not a job for Moliere's overworked serving girl.

We have seen how the positive, progressive aspects of the old culture were dealt with by Communist writers in Das Wort. The old culture and civilization was commonly depicted in quite another fashion in many contributions. It was compared with the new society - and of course found wanting. We have seen this approach already in Béla Balasz's article about Azerbaijanian music, and in F.C. Weiskopf's touching description of the babushka trying out her new reading skills on the Stalin Constitution displayed in the shop 
window. In Julius Hay's "Tanjka macht die Augen auf," a peasant girl comes to Moscow and receives an education at night school; she is soon reading Shakespeare and Tolstoy, adding to her country common sense the benefits of liberal education (Hov. 1937: 59-108). Another Sascinating work in this vein is Erich Weinert's verse composition "Das Gästebuch des Fürsten Jussupoff" ( June 1936: 28-32). The Summer palace of one of the most illustrious families of the ancien negime has been converted into a museum where the workers and collective farmers, the cream of the new society, can come and view the conspicuous wealth of the old one. The peasants, who had lived in poverty and degradation, had built this great showpiece and luxurious dwelling for people who had been corrupted by their position. This great palace, in which was found ". - kein Pot de chambre aus unedlem Storf," was greater than those who inhabited it: "Ein andrer von dieser noblen Geburt / Hatte, zu Bonapartes Zeiten, / In Paris sein halbes Yermögen verhurt /. . . Er ließ an seinen Verwalter schreiben: / Sofort die doppelte Steuer eintreiben!" (29). Herr Jusuporf was a ". . Gentilhomme von Kultur / (er las Diderot, Swift, Clauren und Coethe);" he did not like the soldiers to shoot the peasants when they caused trouble, since ". . Tote scharren kein Yermögen." Instead, his ". . Henker hieß Ohnebrot; / Denn er war ja Herr über Leben und Tod" (29).

The new order did not destroy the palace: "Das ist jetzt u $n$ s e $r$ Haus! Wer es zerstört, / Zerstört nur, was inm selbst gehört!" (30). This enlightened policy has preserved the good of the old culture, the product after all really of those who now visit it: 
Wo einst die drohende schildwache stand, Am Tore zum Propyläum, steht heut ein friedliches Wort an der Wand:

\section{MUSEUY $(31\rangle$}

Prince Yusupov's guestbook has been preserved as well, half filled with the rancy and pretentious scribbling of the dandies and royalty of old Europe, until the hurried entry "Oktober neunzehnsiebzehn" (31). A red army man who had stood watch in the building upon its confiscation had added "KAPITEL II / DER WELTGESCHICHTE" (32). The new visitors are a different lot from the old, peasant delegations "mit schwerfingrigen Händen;" "Da schrieben Hände, zerschunden von Kohlen. / Da schrieben Hände, zum Dichten bestellt" (32). They come from "allen Enden" of the world, and speak in all languages "Lenins und Stalins klare Parolen." ( 32 )

Thus were the progressive and humanistic elements of the old aristocratic culture preserved to be utilized for the cultural revolution in the new society. It should be noted that the German Communist writers followed the Soviet model in this regard with remarkable fidelity. Writers such as Heine were easy to handle, since they represented the progressive bourgeois tendencies of the previous century. Goethe, too important to ignore, is accepted as a great humanist the enlightenment, progressive despite his blue-blood leanings. Das Wort is stretching things, however, when Herwarth Walden places Richard Wagner among the "erbrähig" (Sep. 1938: 9, p. 48). Walter points out that Walden seeks to "capture" Wagner from the Nazis by emphasizing Wagner "Der künstlerische Revolutionär. . " (Walter 479). Walden simply ignores Wagner the 
reactionary politician and anti-semite: "Der politische Wahnwitz des alternden Wagner wurde beschönigt, kaschiert und beinahe beiseitegeschoben" (Walter 479). Such were the lengths which the Popular Front writers went to save German culture from the Nazis and mold it into "progressive" form.

\section{SOYIET CULTURE}

The wisdom and success of Soviet cultural policy in many spheres of activity is highlighted in numerous articles and marginal notes in Das Wort. Original works by Soviet writers appear of ten in translation, and Soviet fine art, theater, music and film are covered regularly. The overall impression one gains from this material is that the Soviet Union is a country where the government has decided that the spiritual and cultural needs of the populace are as important to satisfy as are its material and physical requirements. The government is not content to let such important matters develope chaotically and haphazardly. The result of these active cultural policies is a land fairly teeming with people demanding the products of high humanistic culture.

In a traditional fashion in the Socialist world, Das Wort presents statistics liberally to make this case. The production of books is cited as proof of the rapidly rising cultural level of the people. Balder Olden, relating his travels around the USSR on the occasion of the First Congress of the Soviet Writers Union in 1934, tells us that Maxim Gorky's books alone have reached the fantastic number of "29,7 Millionen Exemplare" ("Anno vierunddreißig in der 
UdSSR," Feb. 1938: 68-78, p. 69). Olden explains the significance of such figures:

In unseren Tagen neigt man mehr dazu, den Verbrauch an Büchern zum Wertmesser einer Kultur zu machen, und soweit dieser Yerbrauch sich in Aurlagenhöhen ermessen laßst, marschierte Rußland schon 1934 so weit voraus an der Spitze aller Nationen, daß eigentlich kein Vergleichen mehr möglich war, daß wir Träger der westlichen Zivilisationen nichts als staunen und uns schämen konnten." (70)

The reader is overwhelmed with figures as the various national literary exhibits at the $1937 / 38$ world's fair are compared. Germany and Italy offer pitiful displays of old editions of classics; the Soviet Union, on the other hand, demonstrates that "Bücher ein täglicher Gebrauchsartikel geworden sind" ("Die Literatur auf der Weltausstellung 1937/38," Mar. 1938: 148-150, p. 149) In the last 10 years 260 million books by Marx, Engels, Lenin and Stalin have been printed; Pushkin alone appeared in an edition of 26 million (149).

A marginal note relates that a subscription edition of the works of Homer, planned at a run of 5,000, received orders for over 200,000 sets. ("Sow jetische Verlegersorgen," Nov. 1938: 157). The athor ("F.E.", Erpenbeck probably) quips that capitalist publishers would do well not to read on (before he cites that amazing figure), since "Neid ist kein schönes Gefühl" (157).

The results of Soviet literary policy are evident to Balder Olden as he travels around the Union in 1934. The "Wißbegier, die Lernbegier, die Kunstfreudigkeit, die sich zugleich die breitesten Massen bemächtigt hat ..." (Feb. 1938: 69). Olden is impressed not only in Moscow, but in the Muslim republics in the south of the Soviet Union ( $74 r f$.$) . He sums up Soviet cultural policy succintly:$ 
"Mitten im Krieg gründen sie Schulen, Bibliotheken, Kinderklubs..." $(78)$.

One such library in Moscow, devoted to foreign literature, exemplifies the growing interest in foreign language and literature in the USSR and the government's active steps to promote that interest. ("Ein Kulturzentrum in Moskau," April 1938: 155-156, Marginal Note). Foreign literature in abundance, as well as Soviet and Russian works in foreign translations can be found at the Zentral-Bibliothek für ausländische Literatur. The library also sponsors lectures by prominent foreign writers and critics (Balasz among them) and readings and recitations in foreign languages (156). The needs of young readers and language-learners are particularly looked arter.

Another reflection of the high level of literary culture in the Soviet Union can be seen by brousing through the numerous used-book stores in Moscow. (Frank Leschnitzer, "In Moskauer Antiquaritaten," Nov. 1937: 173-174) Foreign quibbling about "was es in Moskau nicht gibt," notwithstanding, cornucopia of books, including many German, can be found in these shops: "Wonach man in deutschen Buchhandlungen lange vergebens fahndete - hier entdeckt man es schnell" (173). Leschnitzer's explanation for this phenomenon: "Es sind teils die Bücher ehemaliger Kapitalisten und Gutsbesitzer," or "teils solche, die man als entbehrlich verkaurt, um unentbehrliche darür zu kaufen" (173).

Marginalia and artioles such as those by Balder Olden demonstrated the efficacy of Soviet cultural policy. But in a literary 
journal, the natural focus of attention was on belles lettres.

Maxim Gorky is the Soviet writer who receives the most coverage. Gorky was certainly the most popular of Russian writers who could be considered "Soviet," if not so much for his dates (he was born in 1868) as for the consistent revolutionary stance he had maintained throughout his career. ${ }^{2}$ Gorky is another one of those figures whose huge stature in the world of literature made him indispensible to establish the legitimacy of Soviet literature. In the early days of the Revolution, Gorky was extremely critical of Bolshevik policies and actions, publishing scathing attacks in his journal The Ment Life (Slonim, Fram Chekhor 148). Gorky renewed his pre-Revolutionary European exile in 1918, but by the late Twenties he had reconciled himself to the new regime and was now producing work consistent with the party line in the arts. He is credited with inventing the term "Socialist Realism," and establishing many of the canons of that aesthetic program. ${ }^{3}$ He became an icon of Soviet literature. Personally acquainted with Stalin, he tried to influence the dictator to ameliorate the fate of intellectuals and unorthodox writers (Slonim, From Cheksov 149 ).

Kurt Kesten provided Das Wort readers with a "Literarisches Porträt" of Gorky in his "Maxim Gorki: Der Prophet des Sieges" (Sep. 1936: 6-10). Kersten admonishes the reader to behold “. . beklommen und beschämt... den Weg Maxim Gorkis, dieses ersten proletarischen und revolutionären Schrifstellers der Welt. . ." (6). Gorky is a true son of the people: Kersten describes his colorful and variegated career, stressing Gorky's intimate knowledge of the 
horrible and degrading conditions under which the common people lived in the last decades of Czardom ( $6-7)$. Kersten ascribes Corky's triumphs over adversity to the author's belief ". . . daß gerade der Widerstand gegen seine Umgebung den Menschen formt" ( 7 ). Because of Gorky's lower class origins and history, he is different from the aristocratic or bourgeois writers which had hitherto constituted Russian literature. Gorky had looked to the "volkstümlich" tales and stories of the common people ror his inspiration: "Gorki ist so eng mit dem Wesen des russischen Yolkes verbunden wie nur wenige Dichter Ruflands ...." (9). And Gorky was revolutionary, since he “. . früh erklärt hatte, man müsse mit Gewalt die Rechte des Volkes erkömpren" (9). No mention is made of Gorky's highly critical reactions when this policy was put into action in 1917.

In the atmosphere of the purge trials, Kersten emphasizes Gorky's willingness to see violence used if needed. Gorky: "Ich liebe vornehmlich Menschen der Art, die gewillt sind, sich dem übel des Lebens auf jede Weise zu widersetzen, auch mit Gewalt!" (10). Kersten compares Gorky's attitude with Tolstoy's, who had declared that "Die Gewalt ist das größte Übel!" (10).

Kersten waxes ecstatic as he describes Stalin at Gorky's funeral:

. . Stalin an das Lager des Sterbenden trat und eine Stunde verweilte, um abschied von dem Verkünder der Revolution zu nehmen, der das Lied vom Sturmvogel gedichtet hatte, "aus dessen Schrei die Sehnsucht nach dem Sturm erklingt." Die Kraft des Zornes, die Flamme der Leidenschaft und die Gewißheit des Sieges hören die Wolken aus diesem Schrei . . und er schreit, ein Prophet des Sieges: "Tobe nur, Sturmwind, tobe - immer starker, wilder!". . (10)

Lion Feuchtwanger's comments on Gorky stress his humble origins, and the effect the Russian had on his own development: 
"Durch Corki war mir zum erstenmal eine Idee des russichen

Menschen aufgegangen, nicht der wenigen Tausend, die oben in dem Licht leben, sondern der Millionen unten..." "Gedanken an Corkis Todestag," Mar. 1936: 11-12). Corki's great power to get to the common people was evident to him when he staged "The Lower Depths" ("Nachtasyl") in Munich: "Es war ein großes Wagnis, bayrischen Massen diese russischen Menschen [in the play] vorzuführen . . " (11) Feuchtwanger makes his point by quipping that "Das Volk, selbst ein so fremdes wie das bayrische, verstand ohne weiteres den russischen Volksdichter. Das Stück blieb Jahre hindurch auf dem Spielplan" (11).

Feuchtwanger yields to the $201 K-m y s t i c i s m$ which captivated German intellectuals Right and Lert during this period, finding yet another varient of the word "Volk":

"es war das Volk selber, das Stimme bekommen hatte und sich aussprach. Es war kein Zurall, daß Gorki kaum je Einzelne um ihrer selber willen gestaltet, sondern daß seine Menschen ihren rechten Sinn erst durch ihre 2 ugehörigkeit zur Menge der anderen gewinnen, durch ihre Volkheit. (12)

Gorky died in the Summer of 1936. A year later, his death was attributed to a Trotzkyite plot as part of the second series of show trials. Indicative of the increasingly hysterical tone Das Wort was adopting in this period are comments upon the "revelation" of Gorky's murder by the agents of Trotzky (In Memoriam Maxim Gorky, April 1938: 2-4). The author establishes the literary provinence of this blantently political lead article by beginning with an epigraph from Richand the Thind ("Schuldig! Schuldig!") and quoting Franz Moor at length ("bis hierher und nicht weiter!") ( 2 ). 
"Standhartigkeit" is the point of the last quotation, and

"Treue:"

Diese Standhaftigkeit galt dem sozialistischen Aurbau, diese Treue seinem persönlichen und politischen Freunde Joser Stalin. Deshalb waren die Girtmischer am Werk. Deshalb haben sie schon Lenin zu ermorden versucht. Deshalb haben sie Kirow... (3)

The author (Fritz Erpenbeck presumably) explains how men at the very apex of the Bolshevik leadership had concealed their true motives for decades, and sought to sabotage the Revolution even as they helped make it:

Aber warum? Warum Eestehen alle Angeklagten? Warum machen sie nicht wenigstens den Versuch, vor der örfentlichkeit, vor den mehr als zwanzig ausländischen Pressevertretern $z u$ widerrufen, sich $z u$ entschuldigen, eine Art weltanschaulichen Programms zu entwickeln . . . ? (3)

They had no "Weltanschauung," and were the tools merely of Trotzkyism and Fascism, Euilty of intellectual immorality as well as political perfidy. Foreigners who witnessed the trials found it incredible that these men had been secretly sabotaging "Sozialismus" over so many years, but the author of this work has the explanation: "Ihr ganzes Leben war. . nur noch eine Kette von gefährlichen Meineiden, von Doppelzünglertum . . ." (93).

Gorky was murdered because, as a true man of the people who, like the people, wanted only peace with other nations, he represented the acme of what these elitist henchmen of Trotzky hated: the common people of Russia. He is "gefallen für den Frieden" (4).

What lessons are we to draw from this sordid tale of treachery and deceit? "Dieser Prozeß .. . war eine bedeutungsvolle Demonstration der Stärke - der Stärke des sozialistischen Aurbaus, 
der Stäke und Yolksverbundenheit von Regierung, Partei und Roter Armee" (4). Das Wort did not hesitate to draw the proper conclusions:

"Ziehen wir daraus für unser menschliches, literarisches und politisches Yerhalten gegenüber dem Faschismus und dem vom ihm ausgehaltenen Trozkismus die ernste Lehre: härter, mutiger und wachsamer zu werden.

Das schulden wir, soll unsere Trauer nicht sentimentale, unverbindliche Phrase bleiben, unserm gemordeten Kameraden Maxim Gorki. (4)

In all the "criticism" about Maxim Gorky's work found in Das Wort, there is virtually no comment on the specifically artistic characteristics of his writing which one might expect to find in a literary journal. Beyond the fact that the author had successfully depicted the people of Russian in his stories and novels, Gorky's significance is seen in the fact that he was popular - and that he expressed properly revolutionary attitudes. Little comment especially is found about the quality of Gorky's work in the last years of his life, after he had made his peace with the Bolsheviks and returned permanently to the Soviet Union. His last novel, the huge unfinished Klim Samgin, considered a failure by most objective critics, is left untouched. 9

The political content of his work is all that concerns Das Wort's commentators. It is not actually Gorky's literary output which is of interest. It is the man himself, his class and his upbringing, which is the focus of their attention. Gorky's immense popularity is proor that proletarian literature is well on its way to maturity, and verification of the validity of the literary policies of the Soviet leadership. In other words, praise of Gorky is just another 
way to praise Stalin and the Communist Party leaders.

The only other "Soviet" writer to receive notable attention in Das Wort is Vladimir Mayakousky. Like Gorky, this poet had achieved fame in the last years of Czardom and was an uncomfortable adherent to the rules and regulations which the Party culture bureaucrats could not restrain themselves from promulgating.

Frank Leschnitzer begins his Mayakousky article sycophantically - and threateningly - with the Word of Stalin:

"Ma jakowski war und bleibt der beste, begabteste Dichter unserer Sow jetepoche. Gleichgültigkeit seinem Andenken und seinen Werken gegenüber ist ein Verbrechen." Fast zwei Jahrzehnte sind vergangen, seitdem die "Prawda" diese Worte Stalins verörfentlich hat. Und Stalins Worte hatten, wie stets, auch in diesem Falle das stärkste Gewicht, die stärkste unmittlebare Wirkung. ("Majakowski in deutscher Sprache," Mar. 1938: 111-116, p.111)

It might not seem that there would be much to say after an introducton like that, but in fact Leschnitzer's article is a fascinating analysis of the art of the translator as practised by Hugo Huppert with Mayakousky's verse.5 Huppert's "Nachdichtungen" are compared with those of Johannes $R$. Becher, whose efforts in this area Hupperts criticises (112). A remark which clues the reader into the fact that Frank Leschnitzer is from the sympathetic "bürgerlich" camp of Das Wort's contributors is "Formprobleme sind stets auch Inhaltsprobleme" ( 114$)^{6}$ Leschnitzer is more orthodox in choosing an example of Huppert's Mayakousky for examination. It is an excerpt from the Russian's "Syphillis," a gruesome account of "kolonial-imperialistischer Willkür" (115). Huppert's translation is a ". - vorbildliche Leistung zeitgenössischer Nachdichter-Kunst . . Grauen erhöhend. . . ," which abounds in "unheimliche Wunder an 
Binnenreimen, Assonanzen und Alliterationen" (115). Leschnitzer is not alone in his assessment of Huppert's skill in translation: Anneli Hartmann lists Brecht among Huppert's admirers, and credits him with contributing substantially thereby to the "Entwicklung der sozialistischen deutschen Lyrik (Hartmann 197).?

Although Leschnitzer in his piece does not relate Mayakousky to German literature, and concentrates on Huppert's skill as a translator on a quite technical level, what he was in fact doing, as is demonstrated by Hartmann's article, is contributing to the construction of a tradition out of which a new, socialist literature would be built after the establishment of Soviet power in Germany. That is essentially the intent of the many articles in Das Wort which selected lesser-known German writers from the Kultunerbe for reception of the socialist and proletarian seal of approval. And that is why it seemed entirely appropriate to writers on the Left to reach into a foreign literary tradition, that of Russia and the Soviet Union, to find their cultural antecedants. The criterion for membership in the new culture was not to be nationality, but class background and ideological orthodoxy.

Ideology was of prime concern for Bela Balazs when explaining recent changes in the Soviet theater ("Meyerhold und Stanislawsky," May 1938: 115-121). Usevolod Meyerhold, bold innovator and adherent of the avantgarde Left Front of Art in the Twenties, had been recently replaced as head of the most prestigious Soviet theater by Konstantin Stanislausky, whose naturalistic style easily adapted itselr to the canons of Socialist Realism (Slonim, Soviet 33). 
Balazs sets the tone for his piece by snidely noting that the "Bildungsphilister" in the West will be surprised at this development, since Meyerhold had long dominated theater in the Soviet Union: he was a revolutionary and a party member, whereas the 75 -year old Stanislawsky had changed little since the Revolution (115).

"Revolutionary development" in the Soviet Union is the explanation for this apparent paradox, development which “. - führte zur Liquidierung jener Richtung, welche auf der Bühne Meyerhold vertreten hat" (115). Meyerhold had long been out of step with changes in the country; the final break came upon the occasion of the Anniversary of the Octoberrevolution, when Meyerhold's theater was the only one in the entire Union which did not present a new work appropriate to the event: "Und das hat zu guter Letzt das Schicksal des Meyerhold-Theaters besiegelt. Denn die Meinung des Publikums ist hierzulande die maßgebende Grenze der Freiheit der Kunst" (116).

Here is what happened, according to Balazs: in the early years of the Revolution, "revolutionäre Kultur" and "revolutionäre Kunst" was in the hands of "jene Schichten der bürgerlichen Intelligenz" who had thrown in their lot with the Bolsheviks (116). "Sie haben Mayerhold groß gemacht," not the common people, the workers and peasants, who had been too busy making the Revolution "politisch-organisatorisch gesichert" (116). Later, "Aber auch der treue, ehrlich revolutionäre Teil" of the bourgeios Intelligentsia could not "seine ererbte bürgerliche Kultur verleugnen" (116). The essential contradiction of their position caused them to seek 
apocalyptic solutions: "Sie [the Intelligentsia] wollte nach dem Oktober von heut auf morgen eine auch formal vollkommen neue, nevolutionäre Kunst schaffen" (117). But since the pre-conditions for the new art of a classless society did not yet exist, this group could only produce an art of "negatjven Inhalt, nämlich den der Zerstörung alter Formen: um jeden Preis etwas anderes! (117).

The result of this process was an expressionistic style of art whose primary characteristic was its "emotionelle Unbändigkeit," a good example of which was Meyerhold's "Biomechanics" theory (117). This kind of art, with its "Unbestimmheit ihrer revolutionären Inhalte," led inevitably to "leeren formalismus" (118).8 Meyerhold's mime and masque had become empty ornament and grotesque gesture for its own sake (118).

Since the days of the Proletkult in the Twenties, new Intelligentsia has come into being in the Soviet Union, "eine Intelligenz mit tiefem Bildungsbedürfnis, die sich grundlegend auch darin von der bürgerlichen Intelligenz unterscheidet, daß sie Keine Schicht darstellt: es ist das Volk selbst" (120). The needs of this new intelligentsia of the people have surperseded Meyerhold's asthetics: "Der ewig Neuerer ist veraltet" (120). That is why the aged Stanislausky is now so honored "im jungen Lande der proletarischen Revolution und des sozialistischen Aufbaus" (120). Not because he is a Communist (he is not), or because he had re jected his way of making theater after the Revolution (he had not). No, he is now the most revered Soviet theater-director because he has remained what he was all along: 
der größte Meister seines Handwerks, der die Wirklichkeit fanatisch suchende Künstler, der gröbte Realist der Bühne; er wird geschätzt und geliebt, weil er eine der reinsten Werte der bürgerlichen Kultur unverdorben herüberbrachte in die sozialistische Kultur - wo solche Erbe geschätzt wird. . . . er war der konsquenteste Vertneter des psychologischen Realismus auf dem Theater.

Now, in the 1930's, in the era of "Socialism acheived and won," Stanislawky's, and not Meyerhold's, art meets the needs of the people, because his art ". Kein blobes Nein war, verlor sie ihre Bedeutung nicht, als der Gegenstand der Verneinung end gültig verschwand" (121). Stanislawsky, ever the "aurrichtige bürgerliche Realist," remained true to his principles, thus he "brauchte sich in der neuen, sozialistischen Realität nicht zu wandeln - er wurde im Arbeitsprozeß seines künstlerischen Schaffens von ihr, sozusagen "von selbst" Eewandelt: vom bürgerlichen zum sozialistischen Realisten" (121).

Balazs' piece provides real insight into the thinking of Communist intellectuals in Stalin's day, and is far more readable and comprehensible than similar material by, say, George Lukacs. We see clearly in this article why such importance was attributed to the bourgeois Kulturerbe: with Socialism now mature, and a society of justice and human values well established in the Soviet Union, the "Left-Radical" negativism and nihilsm of the 1920's has been replaced by the optimism and boosterism of the 1930's. Bourgeios realism showed man in conflict with a negative reality, socialist realism shows man in harmony with developing humanistic society. Thus the socialist art of the day has more in common with the bourgeios art of the 19 th century naturalists than with that of the radical 
revolutionaries of the 1920's. That art had its place in the rirst years of revolutionary transformation, when agitation and exaggerated criticism or the old society were required. But in the new environment, nealism is the order of the day, a realism which contributes rather than destroys, which educates rather than tears down, a socialist realism.

\section{GERMAN CULTURE AND THE NEW SOCIETY}

The German Kultunerbe is at the center of the depiction of German culture in the new society. Kurt Treptje's "Kleist im sow jetdeutschen Kolchos" presents an idealized and touching picture of the enthusiastic response or Volga-German collective farmers to a performance of Heinrich von Kleist's Der Zerbrochene Krug (Nov.1936: 58-64). The Kollektivbauern have built "Ein Theater der Fünrhundert in einem Dorf von Tausend"; their capability to both understand and correctly interpret Kleist's classic comedy should not be underestimated: "Die haben großes Interesse gerade für historische Stücke" (59).

An original prologue is spoken by a "Kollektivistenbauernsohn, Ausdruck der neuen Generation, Brücke zwischen Kleist und Sow jetpublikum" (59). Trept je explains that the prolog makes clear that presenting this play is not just an idle amusement:

Die Worte sind nicht zurällig, Form und Inhalt pädagogisches Hilfsmittlel $r$ ür das bessere Verständnis der 2 uschauer, rür kritische Aneignung des bürgerlichen Erbes. 
The actors present Kleist in such a rashion that the collective farmers are fully aware of the social and class factors,". - das reale Zeitbild," involved in the play: "Und vergewaltigen doch nicht den Kleist. Kein Wort seiner geschlossenen, herrlichen Dichtung, keinen Stein seiner Spracharchitektur geben wir preis" (61).

At the play's conclusion, "Sohn der Kollektivisten", the actor who played Büttel, presents the epilog, which" . . enthält das kritische Fazit des Stückes vom Standpunkt der sow jetischen Wirklichkeit" (61). As for Kleist's conclusion:

Der optimistische Schluß kann nicht über die Auswegslosigkeit des Stückes und seines Dichters hinwegtäuschen. Erst in viel späterer Zeit brach das System der Walter, Adame, der Lichte und ihrer feilen Büttel in dem Feuer der vereinten Kraft der Arbeiter - und Bauernmacht zusammen. (61)

The farmers were not satisfied with the ending: "Aber, Genossen, warum wurde Adam nicht bestraft?" ( 63 ). These perceptive remarks hit the mark: "Schon sind wir beim Kern der sow jetischen Kritik an Kleist, bei unserer Kritik an der bürgerlichen Justiz" (63). What they needed, declares someone emphatically, was ". - das neunzehner Jahr und der Tschapajew" (63).9

A middle-school pupil disliked the play because ". . "weil er ein Kleinbürgerliches Ende hat'. . 'ich bin überhaupt gegen bürgerliche Stücke!"” (64). A young teacher sets him straight: "Waren es nicht die bürgerlichen Klassiker, die in der damaligen Zeit den Kampr für den Humanismus führten? Und gerade jetzt spielt in unserem kulturellen Aurstieg die klassischen Kunst eine gewaltige Rolle" (64). One of the company's actors agrees with the teacher, pointing out that under Fascism, "die bürgerliche Klasse" is no 
longer capable of "die Wahrheit ihrer eigenen Wirklichkeit darzustellen" (64). There, not even Schiller's "revolutionäre[n] bürgerliche[n] Freiheitsdramen" can be presented properly, let alone a play rampant with social criticism, such as Kleist's Der Zerbrochene Krug. The actor concludes:

"Nein, Kleist hat keine zufälligen, sondern typische Verhältnisse und Menschen dargestellt und Wahrheiten ausgesprochen, mit denen die bürgerliche Klasse heute nichts mehr anzurangen weiß." (64)

Thus Kleist satisfied the typicality criterion of Socialist Realism, as well as that of fidelity to the real existing social conditions of his time. If he railed to come to the proper revolutionary conclusions in his work, that detracts only slightly from the progressive contribution he made to the art of his time.

A party follows the presentation, watched over in avuncular satisfaction by the Leader:

Stalins Wort ist hier Wahrheit, lebendiges Leben im ganzen Lande. Unter seinem blumengeschmückten Bild steht es mit Liebe geschrieben: Es lebt sich besser, Genossen, es lebt sich fröhlicher...

Two Das Wort pieces examine the relationship to Russia of two ramous German men of letters: Rainer Maria Rilke and Oswald Spengler. Marga Franck discusses Rilke's two journeys to Russia in 1899 and 1900, his conception "des russischen Menschen," and the role he saw for Russia in the Europe of his day ("Rilke und Rußland," July 1938: 92-100).10 An important concept in Rilke's view of the world, "der mystische Begriff des Armen," which found artistic expression in his Stundenbuch in particular, rested upon Rilke's idea of the nobility of the poor Russian peasant (93). Rilke's general 
rejection of materialistic $\mathrm{fin}-d e-s i e c l e$ Europe, and his feeling of rootlessness, were reinforced by his trips to Russia: ". - Gerade aus diesem Gefühl der Heimatlosigkeit sucht und rindet er in Rußland seine geistige Heimat" (93).

Rilke saw in Russians primarily religious characteristics, their "Gottverbundenheit" and innate "Frömmigkeit mit ihrer kindlichen Einfachheit und Schlichtheit" (94-95). He was also fascinated by what he called ". . Das Abwartende in dem Character des russischen Menschen," which was usually seen by Germans as "Trägheit" (95). Rilke thought the Russians were waiting for some great event which would transform the world:

"Ein großes Vergeuden ist der Sinn unseres westlichen Lebens, während im rlachen Nachbarlande alle Krärte sich aurzusparen scheinen rür irgendeinen Beginn, der noch ist, gerade als sollten dort einmal die Kornkammern sein, wenn die anderen, in wachsender Verschwendung verarmten Völker mit hungernden Herzen ihre Heimat verlassen." (95)

Franck is very patient with Rilke's views, which clearly are not in accord with the new Soviet Union as portrayed in Das Wort. Not surprisingly, Rilke's reactions to the Revolution were on the whole negative. Franck describes Rilke's only attempt to actively engage in the political life of his time, his actions in Munich during the German Revolution of 1918 (97-98). Rilke soon turned away from that sort of activism, and retreated to Switzerland and isolation. Most of all he rejected the use of force and violence for any purposes: "Dem langsam werdenden und bauenden Dichter aber war die Cewalt stets fremd, und er hielt sie rür das schlechthin Zerstörende. . "(96). This view is not in accord with Marga Franck's, who qualifies this statement by writing that Rilke fails "zu erkennen, das, wo ein 
neuer Bau aufgeführt werden soll, der alte, morsche weggeräumt werden muß" (96).

Despite Rilke's eschewal of revolution and violence, Franck hesitates to strongly criticise the poet, pointing out that "Rilke sieht trotzdem die Notwendigkeit des großen Sturmes ein, und daß solche reinen und kraftvollen Antriebe bei der Revolution mitgewirkt haben" (99). This remark seems quite out of step with Rilke's actual statements, which Franck cites in the same passage. Rilke writes, for instance, in the preceeding quote, that "Der geistige Mensch müßte ja von vornherein ein Gegner und Leugner der Revolution sein, gerade er weiß ja, wie langsam sich alle Yeränderungen von dauernder Bedeutung vollziehen, . . ." (99).

It is clear that Franck does not wish to attack Rilke at all, despite the poet's unequivocal rejection in principle and word of revolution and the use of force. Franck must deal here with the same dilemma George Lukacs faced when writing about Tolstoy: a writer whose stated views are for the most part in disagreement with Communist policy and thought, yet whose stature and popularity makes it imperative that they be brought into the Kulturerbe. In Rilke's case, Franck simply ascribes the poet's misguided views to his ignorance:

Rus Unkenntnis des unmittelbaren 2 usammenhanges zwischen den ökonomischen-gesellschaftlichen Verhältnissen und dem, was Rilke "geistig" nennt, erschien inm das letzte zugunsten des ersten vernachlässigt.

Rilke's ignorance of Marxism exculpates him, it would seem. Franck implies that, had Rilke lived longer (he died in 1926), he would have come to the realization that the Revolution, despite the 
requisite harshness it entailed, was correct. Franck points out that Marxism had always promoted development of a proletarian culture; even though acheivement of this goal had had to be postponed "nach der Oktoberrevlution zunächst vor den drängenden Aufgaben," things had definitely got better since then: "Seit einigen Jahren aber wird gerade das geistige Erbe nirgends so bewußt geprlegt und lebendig gemacht wie in der Sow jet-Union." (100).

Ernst Bloch pulls no punches about his subject in his piece "Spengler und Rußland" (Aug. 1936: 79-82). His first paragraph sets the tone: "Ein verhinderter Täter ist tot... Der Mann des Untergangs wollte keine Geschichte mehr lehren. Er zog, je länger, je lieber, die Peitsche der Feder vor" ( 79$).$

Bloch sets out to examine Spengler's views on Russia: not those which appeared in the rinal version of Der Untergang des Abendlandes, but the author's original intentions in the first drafts of the book, written shortly before the beginning of World War I (79). Spengler's theories sound pretty silly in Bloch's presentation. There is much terminology surrounded by quotation marks: "antik-apollinischen," "germanisch-faustisch," "Kulturseele," for instance ( 80 ). Russia's culture was to have become dominant in Europe, just as soon as the country could free itself from its "petrinischen Pseudomorphose" ( 80 ). The real Russia "steht noch im Eeschichtslosen Dämmer seiner Yorzeit, es wird noch seine 'Merowingerepoche' geben" ( 80 ).

The war, and especially the Bolshevik victory, brought an end to such ideas: ". . die Rußlandschwärmerei von ehemals verlor 
Antrieb wie Gegenstand" ( 80 ). By 1933, "im rechten "Jahr der Entscheidung,' wurde der Kreuzzug gegen Rußland gepredigt" (81). Bloch does not ascribe Spengler's change of view to noble motives:

"Wenn der Untergang des Abendlandes, der Aurgang Rußlands den Geldbeutel betreffen, dann ändert der "Morphologe" seine "Schau" in weniger als zehn Jahren bis zur Kenntlichkeit um, und der "Zivilisationsekel" verteidigt seine heiligsten Güter. ( 82 ).

Things would have looked quite different, concludes Bloch, had not 1914 intervened, or October 1917, or the defeat of Germany: "Rußland, das deutsche Indien, der Jungbrunnen für die deutsche Seele, . . Das Symbol der Ebene wäre aus keiner Spenglerschrift mehr verschwunden" (82). Things clearly did not turn out that way, though, and the Spenglers and Rilkes of German culture will just have to get used to the real Russia, the Soviet Union whose achievements in the cultural field, matching those in industry and agriculture, figure so prominently in the pages of Das Wort. 


\section{NOTES TO CHAPTER Y}

1 In $\ddot{u b e r}$ naive und sentimentalische Dichtung.

2 Henri Troyat's Gorky is a lively narrative of Gorky's colorful life. For a more detailed treatment of Gorky' literary work, see Marc Slonim From Chekhov to the Revolution. Russian Literature 1900-1917. Slonim's book, although intended as a textbook, is a very readable and informative account of the whole period leading up to the Revolution.

3 James C. Yaughn's Soviet Socialist Realism is a thorough introduction to the subject. For Gorky's role in providing artistic underpinnings for the literature of East Cermany, see Eva Wunderlich's article "Literature in Soviet Occupied Germany" (343r.).

4 Jürgen Rühle's chapter on Gorky and Klim samgin is useful for readers interested in the problem faced by writers who attempt to juggle political loyalty - Parteilichkeit - and artistic integrity ("The Requiem Mass of the Intelligentsia," Literature and Revolution 20-34).

5 The excerpt from Mayakousky's poem "Lenin" in my Chapter IU ( 87-88) may be an example of Huppert's work. It could just as easily be Becher's - he was resident in Moscow during this period. The translation is unattributed, and Das Wort Moskau, generally most reliable for such information, provides none in this case.

For readers interested in the technicalities of translation, Leschnitzers article goes into some detail about the specifics of Russian and German verse which present difficulties to the translator into German (113).

- Leschnitzer was a frequent contributor to Das Wort, specializing in cultivating the Kulturerbe with articles about, for instance, Ludwig Börne (Feb. 1937) and Georg Heym (Oct. 1937).

7 "Aurbau und Demontage eines Denkmals: Zur Majakowski-Rezeption in der DDR-Literatur," Michigan Germanic Studies Viii. 1-2 (1985): 196-227. Hartmann's article is an intriguing examination of the "Reinigen" of the historical facts of Mayakousky's life, his elevation to an icon of Soviet (and subsequently German Democratic) literature, and his subsequent fate in the ups and downs of the ideological-cultural currents in the DDR.

8 Becher's journal Internationale Literatur was conducting a rabid anti-Formalism campaign at this time (Walter 480 ). 
- Chapayeu was a legendary hero of the Civil War. A "man of the people," he was made famous by Dmitry Furmanov's 1923

eponymous novel (Rühle 44).

10 Two books which examine Rilke's life-long fascination with Russia, and its influence on his oeuvre, are Rilke und RuBland and Rilkes Russische Reisen. The first contains a wealth of documentary material: letters, dairy-entires, and poems; the second is analysis and interpretation. 


\section{CHAPTER VI}

\section{CONCLUSIONS}

The image of the Soviet Union as presented in Das Wort was a manirestation of the situration the German Communist writers found themselves in during their Moscow exile. That situation was not just the result of Hitler's take-over in Germany: the roundations had been laid in the 1920's for the total subordination of the Communist Party of Germany to the Comintern and Moscow. The German Communists surrendered their independence of action and policy for the tangible benefits of association with an existing power which professed the same ideology as did they. Thus their own policies came under the control of a foreign country, a situation which did not change for the German Communists until the Fall of 1989, when politics in the Western sense returned to their part of Germany.

Das Wort was a journal whose ostensible raison d'être was promotion of the Popular Front policy, a sensible reaction to the Wazi threat in Europe. But because the presentation of literature and culture which were the special provenance of Das Wort were subordinated to Soviet policy needs, that presentation, the journal itself, and the Popular Front policy were irreparably compromised. The real function of Das Wort became the promotion of the Soviet Union and its leadership.

Hans Magnus Enzensberger's idea that "praise of the leader" 
intrinsically destroys poetry it touches is the key to understanding what occured. Das Wort's presentation of the Soviet Union is in effect nothing but eulogy of Joseph Stalin and his party. The "politics," the Parteilichkeit, the für oder gegen, the need to openly choose sides in the struggle engulring Europe, all come down in the end not to being for or against Adolf Hitler, but to being for or against Joseph Stalin and the Soviet Union.

Culture and literature, to which the Communists ascribed great importance, had to play their role in this process as well. The new artistic credo in the Soviet Union, Socialist Realism, gave writers and artists the task of painting reality not as it is, or they see it, but as it should be, and will be, once the policies of the Party are fully realized. The cultivation of the Kulturerbe, Volkstümlichkeit, "the new man," the primary elements of Socialist Realism, are themes to which contributors to Das Wort return continually. It became the task of this German literary magazine to bring this Soviet concept of "realism" to German literature and to subordinate that literature to the idea that there really is no difference between politics and literature, that literature is merely one aspect of politics, and that politics consists in carrying out the progressive policies of the Party leadership.

Fritz Erpenbeck makes the real intentions of Das Wort clearly known in his Vorwort to the October Revolution Twentieth Anniversary issue ( $N o v$. 1937: 3-7). After summing up the many achievements of the Soviet state in agriculture and industry, Erpenbeck narrows in on the particular focus of Das Wort: literature 
and culture. The Soviet state provides "die weitestgehende staatliche Unterstützung der Wissenschaft und Kunst" which has produced a "socialist" culture, which is ". . gewachsen aus dem großen Erbe der Vergangenheit und das beste dieses Erbes aufhebend . . " (4). What seemed twenty years before "lächerlicher Wunschtraum" is now "Sow jet-Wirklichkeit:" the masses read and understand in their millions Homer, Shakespeare, Cervantes, Goethe, Balzac, and Tolstoy (5). German exiles, whose country had been overwhelmed by barbarians with values totally opposed to the humanistic traditions represented by the literary figures listed above, could only envy the citizens of a country whose wise leadership had brought about this cultural revolution.

Erpenbeck condenses the essence of Socialist Realism into a few words, an aesthetic which is a political program:

.. optimistisch sind die Zukunftsaussichten des jungen Sow jetbürgers - sie realisieren sich in einer optimistischen Realität; optimistisch ist das Scharfen des Sow jetkünstlers der neue Mensch läßt sich nicht anders gestalten, soll das eherne Gesetz aller wahrhaft großen Kunst verletzt werden: der Realismus. Sow jetliteratur: das heißt Gestaltung des positiven Menschen, denn dieser ist die Realität des Menschlichen im Sozialismus. (6)

This was a Soviet reality which could only compel any reasonable individual to agree that the policies and practices of the Soviet leadership were admirable and worthy of emulation. Erpenbeck reveals here the true intentions of Das Wort and its backers:

Fußend auf dem gewaltigen Fundament des bürgerlichen Humanismus, der als Erbe nur aufgehoben werden kann, wenn er kämpferisch verteidigt und ständig neu erorbert wird, ist der antifaschistische Schriftsteller des Westens der Sow jetschrftsteller von morgen ... ( 6 ) 
This is the significance of Das Wort for German literature, the hidden agenda of the journal, and the explanation for much of its material. The "child of the Popular Front," whose task was to mobilize German writers into the struggle against Faschism, actually was recruiting writers for a German literature of the future, a Soviet Cerman literature which would come into being when Nazism had been replaced by Soviet-style Communism.

Erpenbeck concludes the most importent Vorwort written for the journal with the inevitable call to choose sides, to be für oder gegen, but not for or against $F$ ascism, but for or against the Soviet Union:

Die Realität der Sow jetunion, so wie sie heute, nach zwanzig jährigem Bestehen, zu erkennen - zumindest so weit zu erkennen, daß über die notwendige Stellungnahme kein $Z$ weifel mehr bleibt - sollte nicht schwer sein. Ist sie nicht das Land des Friedens? . . . Und ist die Kriegsgerahr nicht rurchtbarer, drohender denn je? Sie ist es. Wer sollte in solchem Augenblick noch zweifeln, wie er Stellung zu nehmen hat - Für oder gegen? Ein Künstler, ein Gelehrter, ein denkender, fühlender Mensch - ? Nein, er kann nicht mehr zweireln, kann nicht mehr zögern: zwanzig Jahre Sow jetunion - diese Realität ist zu groß, um vor ihr gar zu klein und lächerlich werden $z u$ wollen.

When the Socialist Revolution was finally brought to Germany by the Red Army, the German Communist Party had for all intents and purposes long ago ceased to exist as an independent political movement. It had become an administrative organ of the leadership of the Soviet Union. Its elements responsible for the promulgation of culture and literature in the new Socialist Germany had equally surrendered their independence and were now responsible for, in effect, carrying out Soviet Kulturpolitiks on German soil. The 
revolution, both political and cultural, carried out in the Soviet Zone of Occupation in Germany, never was a German Revolution: it was a Russian Revolution made on German soil. It was not a revolution out of the blue, however. It had been in preparation throughout the long frustrating years of exile in the Soviet Union. The vision of what Soviet Germany was to be had already been developed long before as well: it can be seen in the image presented of the Soviet Union in the German exile journal Das Wort. 


\section{REFERENCES}

Abusch, Alexander. ... einer neuen Zeit Beginn. Erinnerungen an die Anfänge unserer Kulturnevolution 1945-1949. Berlin und Weimar: Aurbau Verlag, 1981.

Borland, Harriet. Soviet Literary Theory and Practice during the First Five-Year Plan, 1928-32. New York: King's Crown Press, 1950.

Brown, Edward J. The Proletarian Episode in Russian Literature 1928-1932. New York: Columbia University Press, 1953.

Brutzer, Sophie. Rilkes Russische Reisen. Darmstadt:

Wissenschaftliche Buchgesellschart, 1969.

Caute, David. The Fellow-Travelers. A Postscript to the Enlightenment. New York: The Macmillan Co., 1973.

Carr, E.H. Twilight of the Comintern. New York: Pantheon, 1982.

Cornides, Wilhelm. Die Weltmächte und Deutschland. Geschichte der jüngsten Vergangenheit 1945-1955. Tübingen:

Rainer Wunderlich Verlag, 1957.

Deutsche Literatur im Exil 1933-1945. Text und Dokumente.

Ed. Michael Winkler. Stuttgart: Philipp Reclam jun., 1977.

Duhnke, Horst. Die KPD von 1933 bis 1945 . Köln:

Kiepenheuer und Witsch, 1972.

Ebon, Martin. The Soviet Propafanda Machine. New York: McGraw-Hill Book Company, 1987.

Fischer, Ruth. Stalin and German Communism. With a New Introduction by John C. Legett. New Brunswick (USA) \& London. Transaction Books, 1982.

Flechtheim, Ossip K. Die KPD in der Weimarer Republik. Mit einer Einleitung von Hermann Weber. Frankfurt am Main: Europäische Verlagsanstalt, 1969.

Feuchtwanger,Lion. The Reichstag Fire Trial: the Second Brown Book of Mazi Terror. Intro. by Georgi Dimitrov. Forward by D.N. Pritt, K.C. New York: Howard Fertig, 1969. 
Zur Geschichte der DDR: Von Ulbricht zu Honecker. Series: Die DDR: Realitäten argumente. Herausgegeben von der Fridrich-Ebert-Stiftung. Bonn: Verlag Neue Gesellschart, 1986.

Getty, J.Arch. Origins of the Great Purges. The Soviet Communist Party Reconsidered, 1933-1938. Cambridge: Cambridge University Press, 1985.

Gide, Andre. Return from the USSR. New York: Alfred A. Knopf, 1937.

Hartmann, Anneli. "Aurbau und Demontage eines Denkmals: Zur Ma jakowski-Rezeption in der DDR-Literatur." MiChigan Germanic Studies. VIII 1-2 (1985): 197-228.

Hawkes, Terence. Literature and Propaganda. London \& New York: Meuthen \& Co. Ltd, 1983.

Hayward, Max \& Leopold Labedz. Literature and Revolution in Soviet Russia 1917-62. London: Oxrord University Press, 1963.

- Writers in Russia 1914-1978. Patricia Blake ed. and intro. Preface by Leonard Schapiro. London: HBJ, 1983.

Heller, Mikhail, and Aleksandr Mekrich. Utopia in Power. Trans. Phyllis B. Carlos. New York: Summit Books, 1986.

Hingley, Ronald. Russian Writers and Soviet Society. New York: Random House, 1979.

Istoriia Vtonoi Minovoi Voiny 1939-1945. [History of the Second World War]. Vol.1. Order of the Red Banner Military Publishing House. Moscow: Ministry of Defense of USSR, 1973.

Jaeggi, Urs. Literatur und Politik. Ein Essay. Frankfur am Main: Suhrkamp Verlag, 1972.

Jarmatz, Klaus. Exil in der UdSSSR. Frankfurt am Main: Röderberg-Verlag, 1979.

Kennan, George F. Russia and the West under Lenin and Stalin. Boston and Toronto: Little, Brown and Company, 1961.

- Soviet Foreign Policy 1917-1941. Princeton, New Jersey: D. Van Nostrand Company, Inc., 1960.

Die Kommunistische Internationale. Kurzer historischer Abrib. Institut für Marxismus-Leninismus beim $2 \mathrm{~K}$ der KPdSU. Berlin: Dietz Verlag, 1970.

Krisch, Henry. German Politics under Soviet Occupation. New York: Columbia University Press, 1977. 
Laqueur, Walter. Weimar: A Cultural History 1918-1933.

New York: G.P.Putnam's Sons, 1974.

Lennartz, Franz. Deutsche Schriftsteller des 20. Jahrhunderts im Spiegel der Kritik. 3 Yols. Registerband. Stuttgart: Alfred Kröner Verlag, 1984.

Leonhard, Wolfgang. Child of the Revolution. Trans. and Intro. C.M. Woodhouse. Chicago: Henry Regnery Co., 1958.

Maguire, Robert A. Red Virgin Soll. Soviet Literature in the 1920's. Princeton, New Jersey:

Princeton University Press, 1968.

MoKenzie, Kermit E. Comintern and World Revolution 1928-1943. The Shaping of Doctrine. London and New York: Columbia University Press, 1964.

Medvedev, Roy. Let History Judge. Revised and Expanded Edition. Ed. \& Trans. George Shriver. New York: Columbia University, 1989.

Mehnert, Klaus. "Die Deutschen und die Sow jetmenschen," Osteuropa 17 ( July-Dec.) 1967: 850-860.

Soviet Man and his World. Hew York: Praeger, 1962.

- Der Sow jetmensch. Versuch eines Porträts nach dreizehn Reisen in die Sow jetunion, 1929-1959. Stuttgart: Deutscher Bücherbund, 1960.

Pike, David C. Die Exilproblematik im Spiegel der Emigranten-Zeitschrift Das Wort. Master's Thesis. Portland (Ore.): Portland State University, 1973.

- German Writers in Soviet Exil. Chapel Hill: University of North Carolina Press, 1982.

Raddatz, Fritz J. Traditionen und Tendenzen: Materialien zur Literatur der $D D R$. Bd.1. Frankfurt am Main: Suhrkamp Yerlag, 1972.

Richter, Rolf. "Der Kulturpolitiker A.Abusch und die Sow jetunion." Wissenschaftliche Zeitschrift der Universität Rostock. 23(1974): 439-443. Rostock: Uiversität Rostock, 1974.

Rilke und Rußland. Briefe Erinnerungen Gedichte. Ed. Konstantin Asadowski. Frankfurt am Main: Insel Verlag, 1986.

Rühle, Jürgen. Literature and Revolution. Trans. Jean Sternberg. New York: Frederick A. Praeger, 1969. 
Schapiro, Leonard. The Communist Party of the Soviet Union. New York: Random House, 1959.

Schlenstedt, Silvia, ed. Wer schreibt, handelt. Berlin und Weimar. Aurbau-Verlag, 1986.

Schlawe, Fritz. Literarische Zeitschriften 1910-1933. Zweite Auflage. Stuttgart: J.B.Metzlersche Yerlagsbuchhandlung, 1965.

Slonim, Marc. From Chekhov to the Revolution. Russian Literature 1900-1917. New York: Oxford University Press, 1962.

- Soviet Russian Literature. Writers and Problems. Second Revised Editon. New York: Oxford University Press, 1977.

Strong, Anna Louise. The New Soviet Constitution. A Study in Socialist democracy. New York: Henry Holt \& Co., 1937.

Iur Tradition der deutschen sozialistischen Literatur. 4 vols. Published by Academy of Arts of DDR. Berlin und Weimar: Aufbau-Verlag, 1979.

Trapp. Frit jhof. Deutsche Literatur zwischen den Weltkriegen II: Literatur im Exil. Bern: Peter Lang, 1983.

Troyat, Henri. Gorky. Trans. Lowell Bair. New York: Crown Publishers, Inc., 1989.

Ullam, Adam B. Stalin: the Man and his Era. New York: Viking Press, 1974.

Vaughan, James C. Soviet Socialist Realism: Origins and Theory. New York: St. Martin's Press, 1973.

Walter, Hans-Albert. Deutsche Exilliteratur 1933-1950. Bd. A: Exilpresse. Stuttgart; J.B. Metzler, 1978.

Weber, Hermann. Die Wandlung des deutschen Kommunismus. Die Stalinisierung der KPD in der Weimarer Republik. 2 Yols. Frankfurt am Main: 1969.

Wegener, Matthias. Exil und Literatur. Deutsche Schriftsteller im Ausland 1933-45. Frankfurt am Main: Athenäum, 1968.

Das Wort: Literarisches Monatsheft. 11 Volumes. Register. Berlin: Rütten \& Loening, 1968.

Das Wort: Moskau 1936-1939. Bibliographie einer Zeitschrift. Ed. Gerhard Seidel. Forward Hugo Huppert. Berlin: Aufbau-Verlag, 1975. 
Wunderlich, Eva C. "Literature in Soviet-Occupied Germany, Thought: Fondham University Quarterly XXXIII, No. 126 (1957): $338-366$.

Zammito, John H. The Great Debate: 'Bolshevism' and the Literary Left in Germany 1917-1930. New York: Peter Lang Publ. Inc., 1984.

Zsurfa, Joseph. Bela Balazs, The Man and the Artist. Berkefy: University of California Press, 1987. 